\title{
Ostracoda (Myodocopina) of the Hawaiian Islands ${ }^{1}$
}

\author{
Louis S. Kornicker, ${ }^{2,4}$ Elizabeth Harrison-Nelson, ${ }^{2}$ and S. L. Coles ${ }^{3}$
}

\begin{abstract}
Ostracoda (Myodocopina) from four of the Hawaiian Islands (Kaua'i, Moloka'i, Maui, and Hawai'i) are identified, and a new species, Pterocypridina colesi Kornicker \& Harrison-Nelson, that was present on all the Islands is described and illustrated, including all five instars and the adult male and female. The genus was not previously known from the area, and its ontogeny had not been described. The number of species collected on the Islands varied from two on Moloka'i to six on Kaua'i.
\end{abstract}

ThIS EFFORT Is a continuation of the study of the myodocopid Ostracoda of the Hawaiian Islands (Figure 1) and other Pacific islands (Johnston Atoll, American Samoa) based on collections made by staff of the Bishop Museum (Honolulu, Hawai'i) while conducting studies of the marine biotic community. The ostracodes described herein were collected from four islands: Kaua'i (Figure 2), Moloka'i (Figure 3), Maui (Figure 4), and Hawai'i (Figure 5).

\section{MATERIALS AND METHODS}

Sampling methods used at the stations are described in Coles et al. (2003). Ostracodes were retained with other macroinvertebrates from washings of coral rubble and macroalgae passed through a $0.5 \mathrm{~mm}$ mesh screen, preserved in $70 \%$ ethanol, and then sorted from the samples in the laboratory at Bernice P. Bishop Museum in Honolulu (S. L. Coles, 2005 , in lit.). Depth range of collections was $0-15 \mathrm{~m}$.

\footnotetext{
${ }^{1}$ Manuscript accepted 19 May 2009.

${ }^{2}$ Department of Invertebrate Zoology, National Museum of Natural History, Smithsonian Institution, Washington, D.C. 20013-7012.

${ }^{3}$ Department of Natural Sciences, Bishop Museum, Honolulu, Hawai'i.

${ }^{4}$ Corresponding author (e-mail: kornickl@si.edu).
}

Pacific Science (2010), vol. 64, no. 2:233-283

doi: $10.2984 / 64.2 .233$

(C) 2010 by University of Hawai'i Press

All rights reserved

\section{Abbreviations}

All measurements are in millimeters. In the illustrations, arrows generally indicate the anterior, roman numerals indicate the endites, arabic numerals indicate the number of the article on the appendage, small letters identify bristles, "esoph" is short for esophagus, "CO" denotes copulatory organ.

\section{RESULTS}

Table 1 shows the number of species collected from all surveys conducted in the Hawaiian Islands. A total of 17 species (11 new) was collected on all five of the main Hawaiian Islands and French Frigate Shoals in the Northwestern Hawaiian Islands. Numbers of species found varied from two on Moloka' $i$ to 15 on O'ahu (Kornicker 1976, 1978, Kornicker et al. 2007; this paper). The substantially higher number of species found on O'ahu is undoubtedly related to the much greater sampling effort that has been done on that island. However, it is interesting that the new species (Pterocypridina colesi) was encountered only in the collections from the four other Hawaiian islands and not from French Frigate Shoals.

By comparison, the collection of the myodocopid Ostracoda from Johnston Atoll contained two species, both new (Kornicker and Harrison-Nelson 2005), and the collection from American Samoa contained three species, two new (Kornicker and HarrisonNelson 2006). Six additional species were reported from Samoa by Poulsen $(1962,1965)$. Johnston Atoll and the Hawaiian Islands had no species of myodocopid ostracodes in com- 


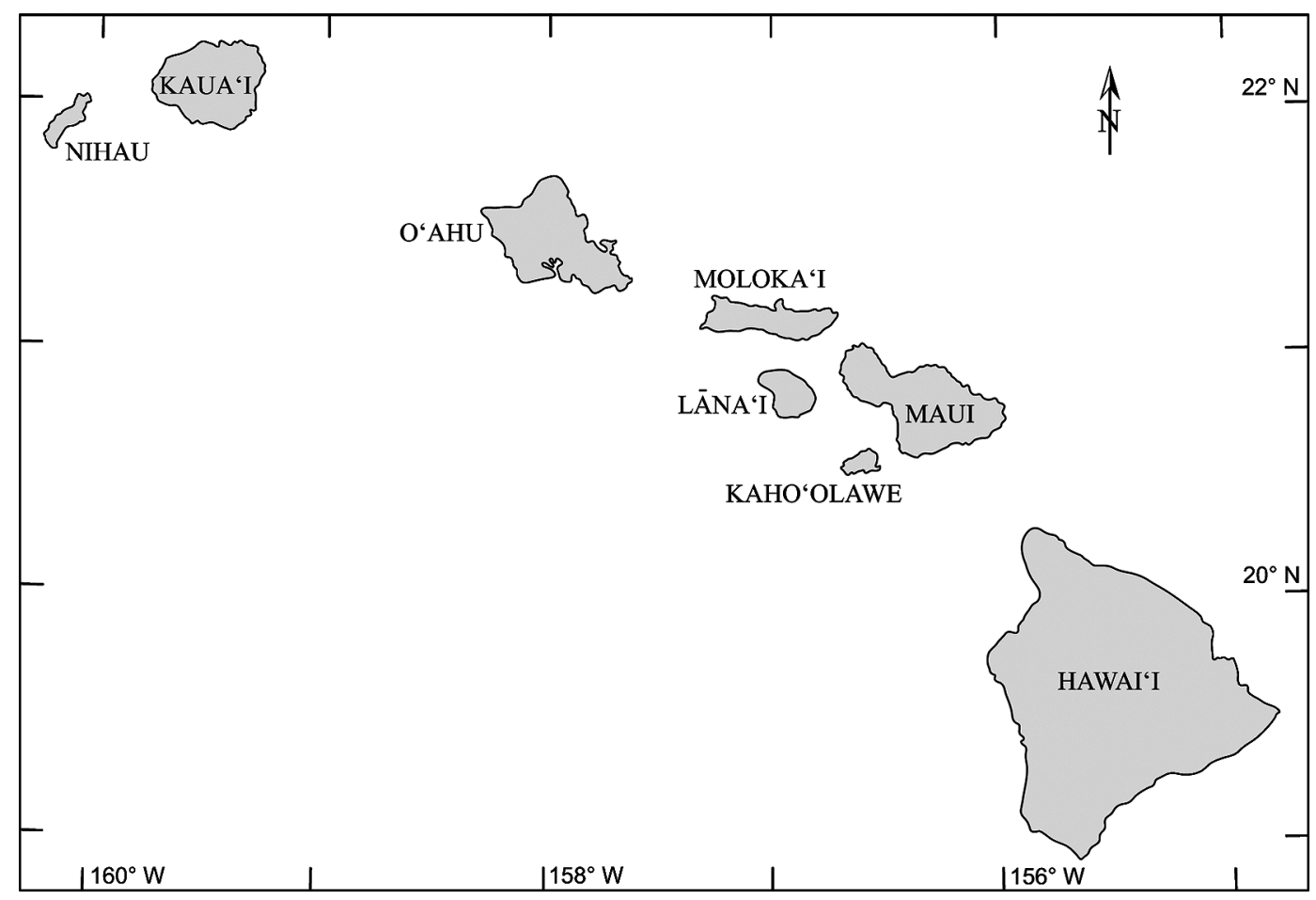

Figure 1. Map of the Hawaiian Islands.

mon, and only one of the species in American Samoa was also present in the Hawaiian Islands.

\section{TAXONOMIC TREATMENT}

\section{Disposition of Specimens}

Most specimens have been deposited in the Bishop Museum, Honolulu, Hawai'i, and have been assigned врвм-S catalog numbers. Some specimens of each species have been deposited in the National Museum of Natural History, Smithsonian Institution, Washington, D.C., and have been assigned UsNM catalog numbers.

Order Myodocopida Sars, 1866 Suborder Myodocopina Sars, 1866 Superfamily Cypridinoidea Baird, 1850

Family Cypridinidae Baird, 1850

Subfamily Cypridininae Baird, 1850

Genus Cypridina Milne-Edwards, 1840
TyPe species: Cypridina Renaudii MilneEdwards, 1840:409, by monotypy.

COMPOSITION AND Distribution: Although 27 species are recognized as species of Cypridina sensu Poulsen (1962:255), only 18 are sufficiently known to recognize at the species level (Kornicker et al. 2007). Known from the Indian and Pacific oceans between latitudes of about $35^{\circ} \mathrm{N}$ and $30^{\circ} \mathrm{S}$, planktonic, and demersal (Kornicker 1991:28).

Cypridina alpha Kornicker et al., 2007

Cypridina alpha Kornicker et al., 2007:25, figs. $10-17$.

HOLOTYPE: вРвм-S 12852, ovigerous female on slide and in alcohol.

TyPE Locality: Sta. 7, 18 Jan. 2001, Canoes, Waikìkī, O‘ahu.

material examined: Kaua'i: Sta. Har4, Port Allen Harbor entrance, врвм-S 14529, 1 adult ?female. Moloka'i: Sta. H1, Hale O 


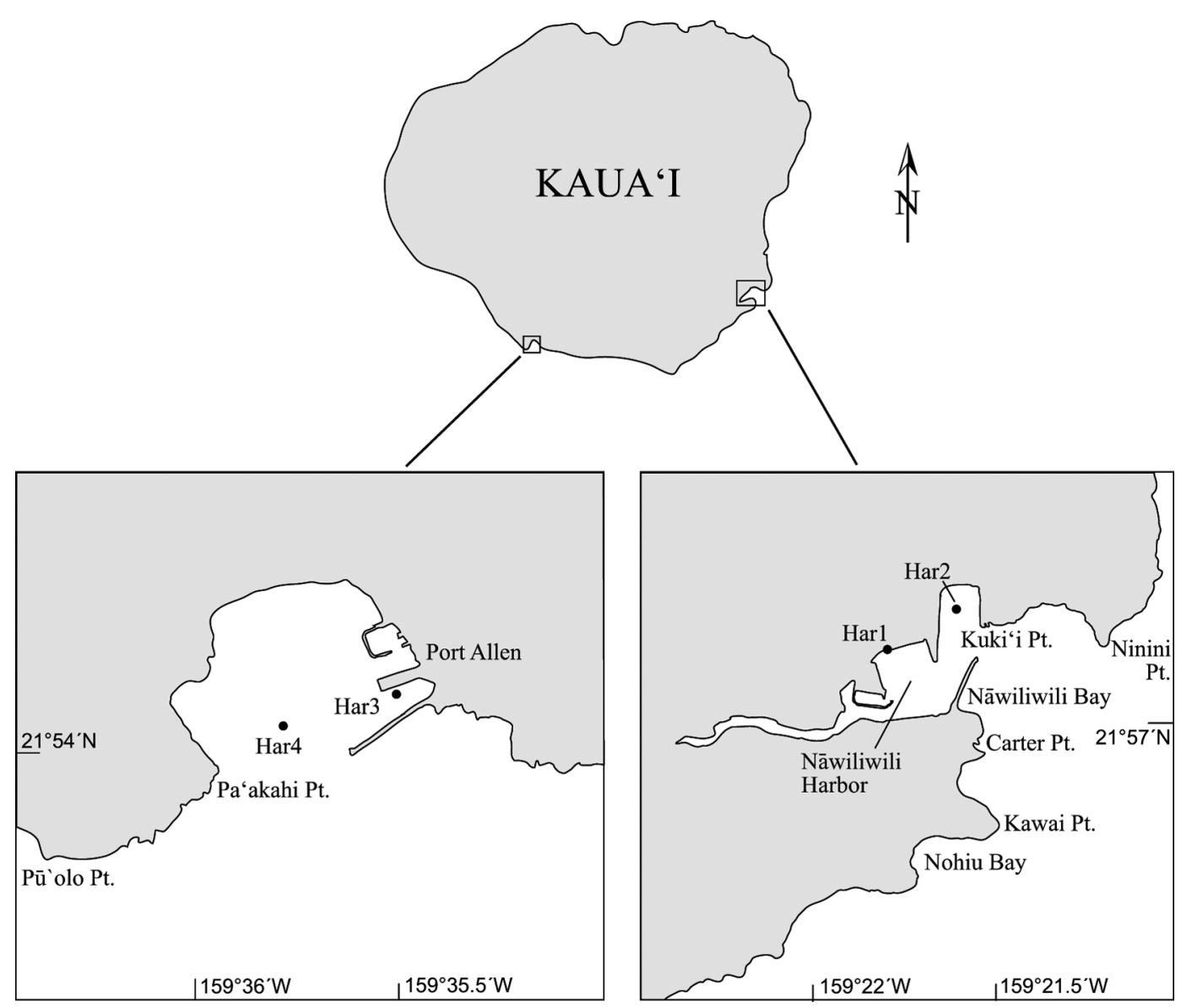

Figure 2. Map of Kaua'i showing location of stations sampled by P. Reath.

Lono within small-boat harbor, вРвм-S 14530, 1 ovigerous female; Sta. H2, Hale O Lono reef outside small-boat harbor, врвм-S 14531, 1 adult female; Sta. H3, Kaunakakai reef, usNm 1121725, 1 adult female; врвм-S 14532, 6 adult females (some ovigerous); врвм-S Sta. H4, Kaunakakai dock, USNM 1121735, 1 specimen; врвм-S 14533, 67 specimens. Big Island, Hawai'i: Sta. H1, Kawaihae reef, врвм-S 14534, 12 adult males, 1 ovigerous female, 1 juvenile ?male; Sta. H2, Kawaihae Harbor, USNM 1121726, 1 specimen; врвм-S 14535, 11 specimens; Sta. H3, Leleiwi Point, USNM 1121738, 1 juvenile; врвм-S 14536, 1 adult female, 1 juvenile;
Sta. H4, Hilo Harbor, usnm 1121739, 1 specimen; врвм-S 14537, 2 specimens. Maui: Sta. H3, Mā'alaea reef, USNM 1121737, 1 ovigerous female; врвм-S 14539, 1 ovigerous female; Sta. H4, Mā'alaea Harbor, UsNm 1121736, 1 ovigerous female; врвм-S 14538, 1 ovigerous female; Sta. M1, Mā'alaea outside, usNm 1121729, 1 female; врвм-S 14731, 7 females. Sta. M1, Hilo Harbor, 2 specimens.

Distribution: French Frigate Shoals; main Hawaiian Islands: Kaua'i, O'‘ahu, Moloka'i, Maui, and Hawai'i.

SUPPLEMENTARY DESCRIPTION OF adult Female: Carapace size (length, 


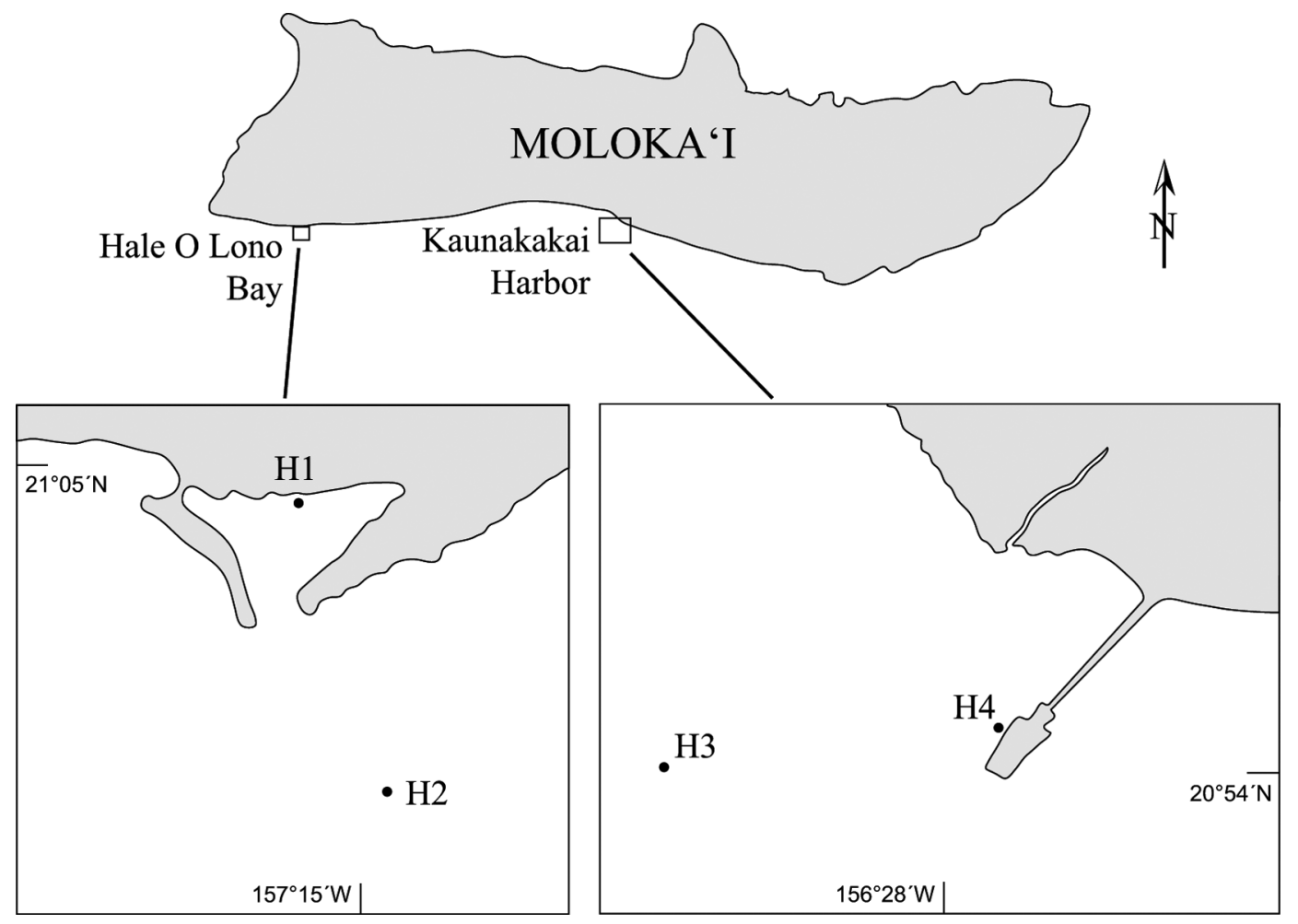

FIgure 3. Map of Moloka'i showing location of stations sampled by P. Reath.

height in mm): врвм-S 14529, 1.48, 0.79; врвм-S 14531, 1.49, 0.85; врвм-S 14530, $1.48,0.81$.

Genus Paravargula Cohen \& Kornicker, 1975

Paravargula Poulsen, 1962:202 [nomen nudem].

Paravargula Cohen \& Kornicker, 1975:23 [designated type species].

TyPe species: Paravargula ensifera Poulsen, 1962.

COMPOSITION AND DisTribution: This genus includes seven species from the Philippines, Singapore, Kei Islands, South Africa, Enewetak, Taiwan, American Samoa, Australia, and the Hawaiian Islands ( $\mathrm{O}^{`} \mathrm{ahu}$, Kaua'i, and Moloka'i).

Paravargula trifax Kornicker, 1991

Figure $6 A$
Paravargula sp. Kornicker, 1991:217.

Paravargula trifax Kornicker, 1991:5, figs. 24.-Kornicker et al., 2007: 11, figs. 1-9.

HOLOTYPE: USNM 158322, adult female on slide and in alcohol.

TYPE LOCALITY: Enewetak lagoon.

distribution: Enewetak lagoon, Enewetak Atoll; American Samoa; Hawaiian Islands (Kaua'i, O'ahu, and Maui).

SUPPLEMENTARY DESCRIPTION OF Adult Female: Carapace size (length, height in mm): врвм-S 14542, 2.60, 1.37.

SUPPLEMENTARY DESCRIPTION OF ADUlT MALE: Carapace size (length, height in $\mathrm{mm}$ ): USNM 1121758, 2.33, 1.14; врвм-S 14541, 2.16, 1.08 .

ADDITIONAL SPECIMENS: BPBM-S 14541, 1 adult male; врвм-S 14541, врвм-S 14543, 45 undissected specimens in alcohol; в ввм-S 14544, 1 specimen. 


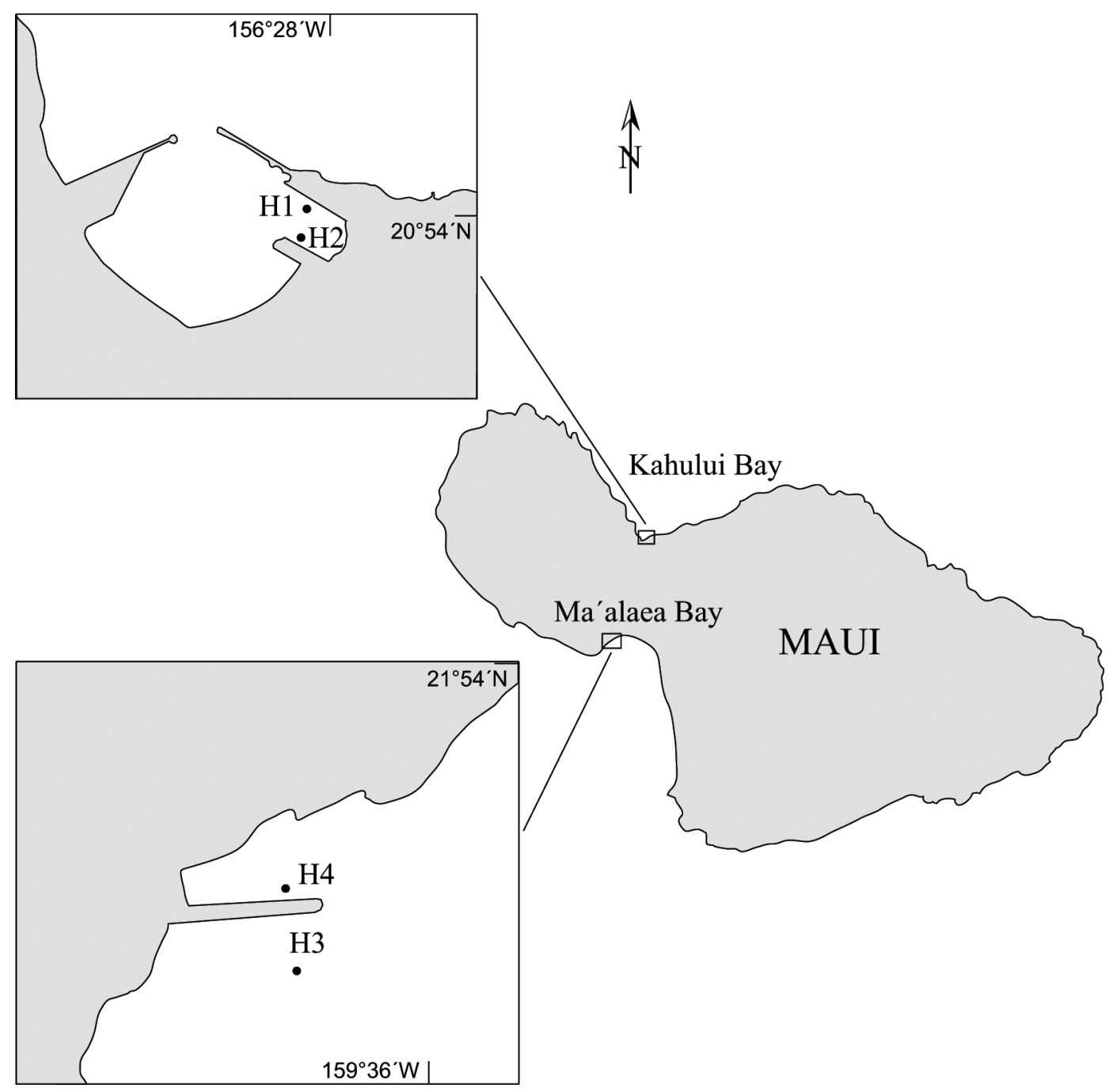

FigURE 4. Map of Maui showing location of stations sampled by P. Reath.

Genus Pterocypridina Kornicker, 1975

TyPe species: Pterocypridina excreta Poulsen, 1962 (subsequent designation, Kornicker, 1975:142).

COMPOSITION AND DisTribUtion: This genus contains 10 species from off Thailand, Singapore, SE Australia, SE North America, and Madagascar (Poulsen 1962:234, Kornicker 1983:1, Kornicker and Poore 1996:67,
Kornicker and Thomassin 1998:50) and Hawai' $i$ (this paper).

DIAGNOSIS: Poulsen (1962:234) presented a diagnosis of the genus based on three species, of which the adult male was known for only one species, and he considered the referral of one of the species doubtful. Kornicker (1983) reviewed the genus, including two additional species, and proposed an informal Pterocypridina Group based on the presence 


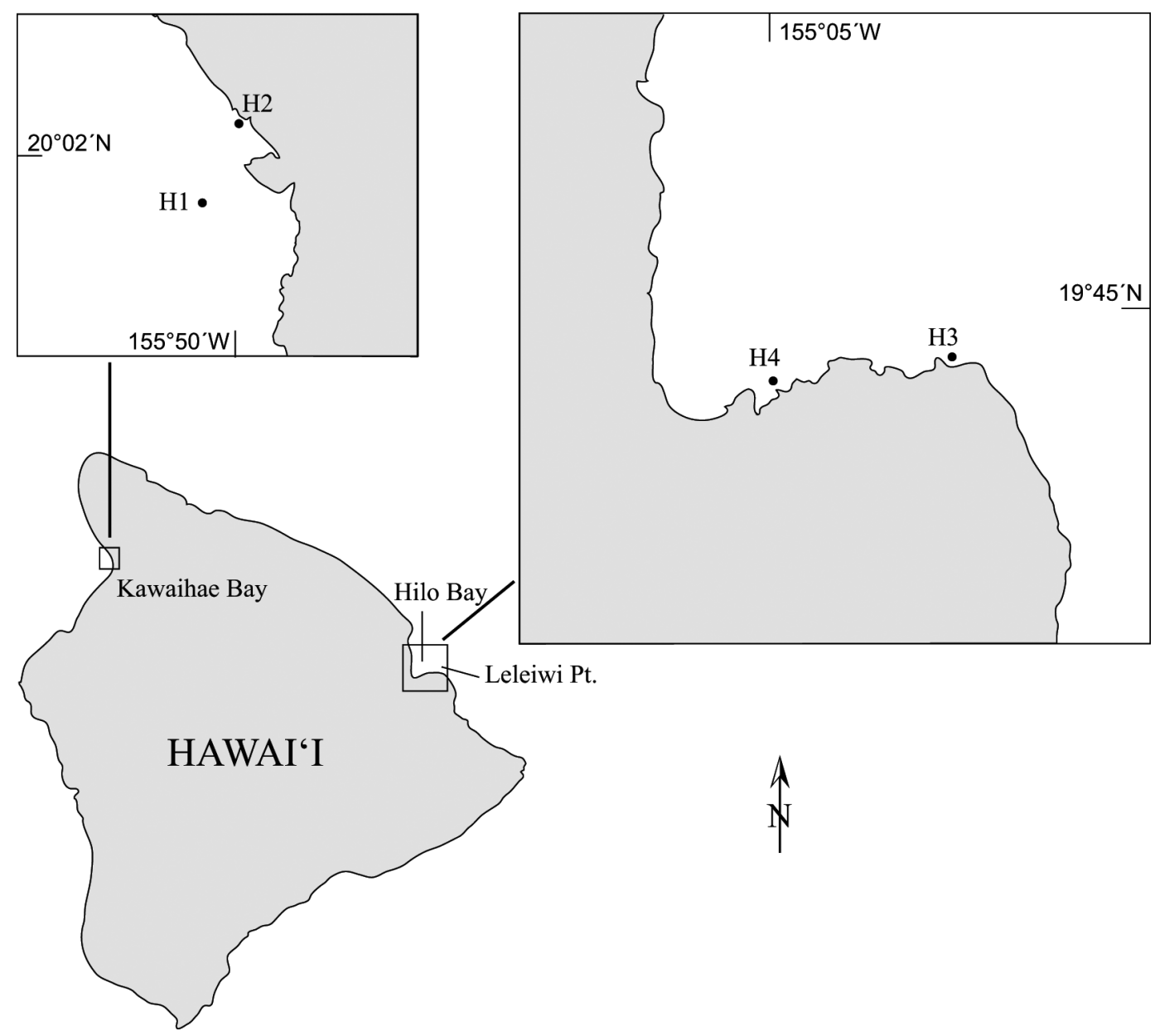

Figure 5. Map of Hawai'i showing location of stations sampled by P. Reath.

of a single large terminal sucker on the b- and c-bristles of the first antenna of adult males. In other groups having a single sucker on the b- and c-bristles, the sucker is subterminal. However, many of the species referred to the genus are known only from females and are doubtfully assigned to the genus.

Pterocypridina colesi Kornicker \& HarrisonNelson, n. sp.

Figures $6 B-7,7-28$

etymology: Named in honor of Steve L. Coles, Bernice P. Bishop Museum, for his contribution to the knowledge of the marine invertebrates of Hawai' $i$.

ноцотуре: врвм-S 14518, adult female on 4 slides and in alcohol.

type locality: Kaua'i, Sta. Har3, Port Allen main docks.

paratypes: Kaua'i: Sta. Har3, usnm 1121656 , partly dissected adult female in alcohol; в ввм-S 14519a, 14519b, 2 undissected adult females in alcohol; в ввм-S 14520, 4 undissected juveniles in alcohol; врвм-S 14521, instar IV in alcohol; врвм-S 14522, 1 dissected instar II (sex unknown) on slide and in alcohol; врвм-S 14526, 9 specimens; врвм-S 
TABLE 1

Distribution of Myodocopid Ostracode Species in Vicinity of Kaua'i, O`ahu, Moloka‘i, Hawai'i , Maui, and French Frigate Shoals

\begin{tabular}{|c|c|c|c|c|c|c|}
\hline & Kaua'i & O'ahu & Moloka'i & Hawai'i & Maui & $\begin{array}{c}\text { French Frigate } \\
\text { Shoals }^{a}\end{array}$ \\
\hline \multicolumn{7}{|l|}{ Cypridinidae } \\
\hline Cypridina alphad & + & + & + & + & + & + \\
\hline Cypridina iotad & - & + & - & - & - & - \\
\hline Paravargula trifaxd & + & + & - & - & + & - \\
\hline Pterocypridina colesi ${ }^{e}$ & + & - & + & + & + & - \\
\hline \multicolumn{7}{|l|}{ Pseudophilomedidae } \\
\hline Harbansus barnardic & - & + & - & - & - & - \\
\hline Harbansus boxd & + & - & - & - & - & + \\
\hline \multicolumn{7}{|l|}{ Cylindroleberididae } \\
\hline Cylindroleberis kappa ${ }^{d}$ & + & + & - & + & - & - \\
\hline Microasteropteron youngib & - & + & - & - & - & + \\
\hline Parasterope gammad & + & + & - & - & _- & - \\
\hline Parasterope iota ${ }^{d}$ & - & + & - & - & - & - \\
\hline Parasterope moseri $^{e}$ & - & + & - & - & - & + \\
\hline Parasterope omegad $^{d}$ & - & + & - & - & - & - \\
\hline Parasterope sigma ${ }^{d}$ & - & + & - & - & - & - \\
\hline Parasterope thetad & - & + & - & - & - & - \\
\hline Synasterope deltad & - & + & - & - & - & - \\
\hline \multicolumn{7}{|l|}{ Sarsiellidae } \\
\hline Ancobenia bawaiiensis ${ }^{b}$ & - & + & - & - & - & - \\
\hline Euarsiella janiceae $b$ & - & + & - & - & - & - \\
\hline Total species & 6 & 15 & 2 & 3 & 3 & 4 \\
\hline
\end{tabular}

${ }^{a}$ Reported in Kornicker (1976:1, 1978:45), Kornicker et al. (2007:9).

${ }^{b}$ Kornicker (1976).

${ }^{c}$ Kornicker (1978).

${ }^{d}$ Kornicker et al. (2007).

${ }^{e}$ This paper.

14540, male instar $\mathrm{V}$ on slides and in alcohol. Moloka'i: Sta. H4, врвм-S 14528, 1 specimen in alcohol; в ввм-S 14523, 8 specimens in alcohol; врвм-S 14728, 1 instar III on slide and in alcohol. Hawai'i: Sta. H4, Hilo Harbor, врвм-S 14524, 2 specimens (1 early instar). Hawai'i, Sta. M1, врвм-S 14525, 3 specimens; USNM 1121659, 1 specimen. Maui: Sta. H2, Kahului Harbor Pier 2, врвм-S 14729, 30 specimens; USNM 1121840, 2 instar I specimens in alcohol and on slide; Sta. M3, Kahului Harbor Pier 1, 1996, врвм-S 14527, 29 specimens; врвм-S 14528, 1 male; UsNm 1121658, 1 male on slide and in alcohol.

Distribution: Hawaiian Islands (Kaua'i, Moloka'i, Maui, and Hawai'i).

DESCRIPTION OF ADUlT FEMALE (Figures $6 B-7,7-12)$ : Carapace oval in lateral view, with prominent rostrum, incisure, and caudal process (Figures $6 B-H, 11-12 A-C$ ). Rostrum with small lateral lobe and rounded tip; tip of caudal process linear; narrow crescentlike process extends past valve edge at anteroventral curvature of valve. Dorsal edge of left valve extends past dorsal edge of right valve (Figure $6 B, G$ ).

Ornamentation: Outer surface of valves with small, shallow, rounded fossae (not visible on all specimens) (Figure 6G); on some specimens only part of edges of fossae visible and appear as crescents. Outer surface of valve with curved row of about 12 connected minute spines extends from inner end of incisure to anterior edge of valve ventral to incisure (Figure 6B, $G$ ).

Chromatophores: Chromatophores appearing black on preserved specimens widely distributed on valves; some appear as closely packed particles (Figure $6 B, D$ ), and some 


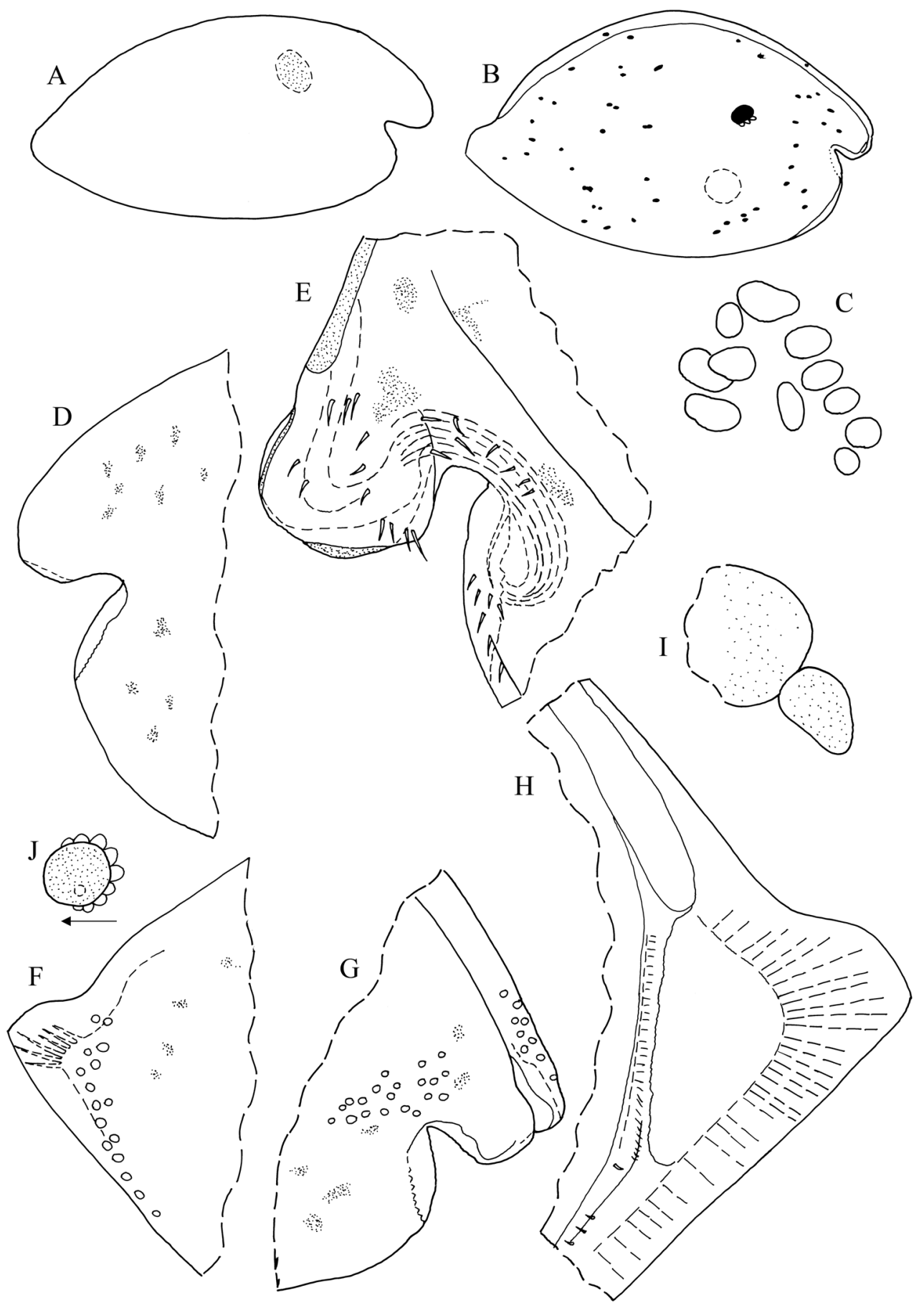

Figure 6. A, Paravargula trifax Kornicker et al., врвм-S 14551, adult male, carapace length 2.16 mm. B-7, Pterocypridina colesi, holotype, врвм-S 14518, adult female: $B$, complete specimen, length $2.20 \mathrm{~mm}$; $C$, central adductor muscle attachments of right valve, inside view; $D$, anterior left valve, outside view; $E$, anterior right valve, inside view; $F$, posterior end of carapace from right side; $G$, anterior carapace from right side; $H$, posterior end right valve, inside view; $I$, medial eye and Bellonci Organ; $\mathcal{Z}$, left lateral eye. 
have anastomosing structure (Figure 12I). Chromatophores absent from valves in vicinity of lateral eye and central adductor muscle attachments, and in isthmus area extending from dorsal edge of valves to central adductor muscles. Similar black structures present on body and some appendages.

Infold (Figure 6E,H): Broad infold present along anterior, ventral, and posterior edges of valves. Narrow list present along ventral edge of valves. Numerous bristles form a continuous row along list of anteroventral infold and anterior part of ventral infold (Figure $6 E$ ). List along ventral infold with widely separated minute bristles. Bristles present on infold of rostrum (Figure $6 E$ ). Infold or caudal process with anterior ridge with minute protuberances along posterior edge; abundant short, dark lines (?pores) visible beneath or within the ridge perpendicular to edge of ridge (Figures $6 H, 12 \mathrm{C}$ ). Infold of caudal process of left valve with narrow projecting crescentlike process near dorsal end of inner edge of infold (Figure 12A).

Selvage: Broad lamellar prolongation present along rostrum and incisure, divided at inner end of incisure. Narrow lamellar prolongation along ventral edge of valve. Distal edge of lamellar prolongation smooth.

Hingement: Narrow ridge (with rounded posterior end) present along inner edge of infold between posterior juncture and dorsal end of caudal process of free margin of right valve (Figure 6H). On closed carapace, ridge fits into groove on infold of free margin of left valve (groove crosshatched in Figure $12 A)$. Small projecting crescent projects from dorsal end of inner edge of infold of caudal process of left valve and presumably butts against posterior end of ridge of right valve when carapace closed. Free margin of right valve anterior to anterior junction with narrow ridge (with rounded anterior end) just within dorsal edge of valve posterior to rostrum (Figure 6E). Left valve with depression just within dorsal edge of valve posterior to rostrum. Depression in left valve accommodates ridge of right valve when carapace closed. Narrow striated dorsal edge of rostrum of each valve (striations more evident on right valve) may interlock when carapace closed.
Central adductor muscle attachments (Figure $6 C$ ): With about 11 oval attachments.

Nodules: Specimens in collection with numerous scattered oval nodules within valves.

Carapace size (length, height in $\mathrm{mm}$ ): Holotype (врвм-S 14518), 2.20, 1.37; USNм $1121656,2.15,1.33$; врвм-S 14519a, 14519b, 2 specimens, $2.22,1.35 ; 2.15,1.32$.

First antenna (Figure 7 $A, B$ ): Article 1 bare. Article 2 with minute dorsal spine or indentation at midlength. Article 3 short, with 2 bristles ( 1 ventral, 1 dorsal). Article 4 with 2 short distal bristles (1 ventral, 1 dorsal). Sensory bristles of article 5 with 8 long filaments (6th filament of holotype stouter than others) followed by 3 shorter and more slender filaments with few marginal spines; tip of bristle bifurcate. Article 6 with short terminal medial bristle with few minute marginal spines. Article 7: a-bristle longer than bristle of article 6 , with few marginal spines; b-bristle with 4 marginal filaments, some with few marginal spines; section of b-bristle distal to last filament with few marginal spines and minute process at tip; c-bristle much longer than bbristle (tip of bristle missing on specimen examined; with 9 marginal filaments, some with spines, on remaining part). Article 8: $\mathrm{d}$ - and e-bristles filamentlike, shorter than b-bristle; f-bristle about same length as c-bristle (tip of bristle missing on specimen examined, with 9 marginal filaments, some with spines on remaining part); g-bristle (not shown on illustrated limb) about same length as c-bristle (tip missing on specimen examined, with 10 filaments with marginal spines on remaining part).

Second antenna (Figure 7C,D): Protopod with short distal medial bristle. Endopod with 2 articles: article 1 with 4 anterior bristles (2 shorter than others); article 2 short, with long terminal filament. Exopod: bristle of 2 nd article reaching tip of 9th article, dorsal margin with short slender spines proximally and long hairs distally, ventral margin with long hairs and few stout subterminal spines; bristles of articles 3-8 long, with natatory hairs (proximal hairs on some bristles shorter, fairly stout, spinelike); 9th article with 4 bristles with natatory hairs, dorsal bristle short. Article 3 with minute lateral spine near ventral margin. Article 4 of right limb 

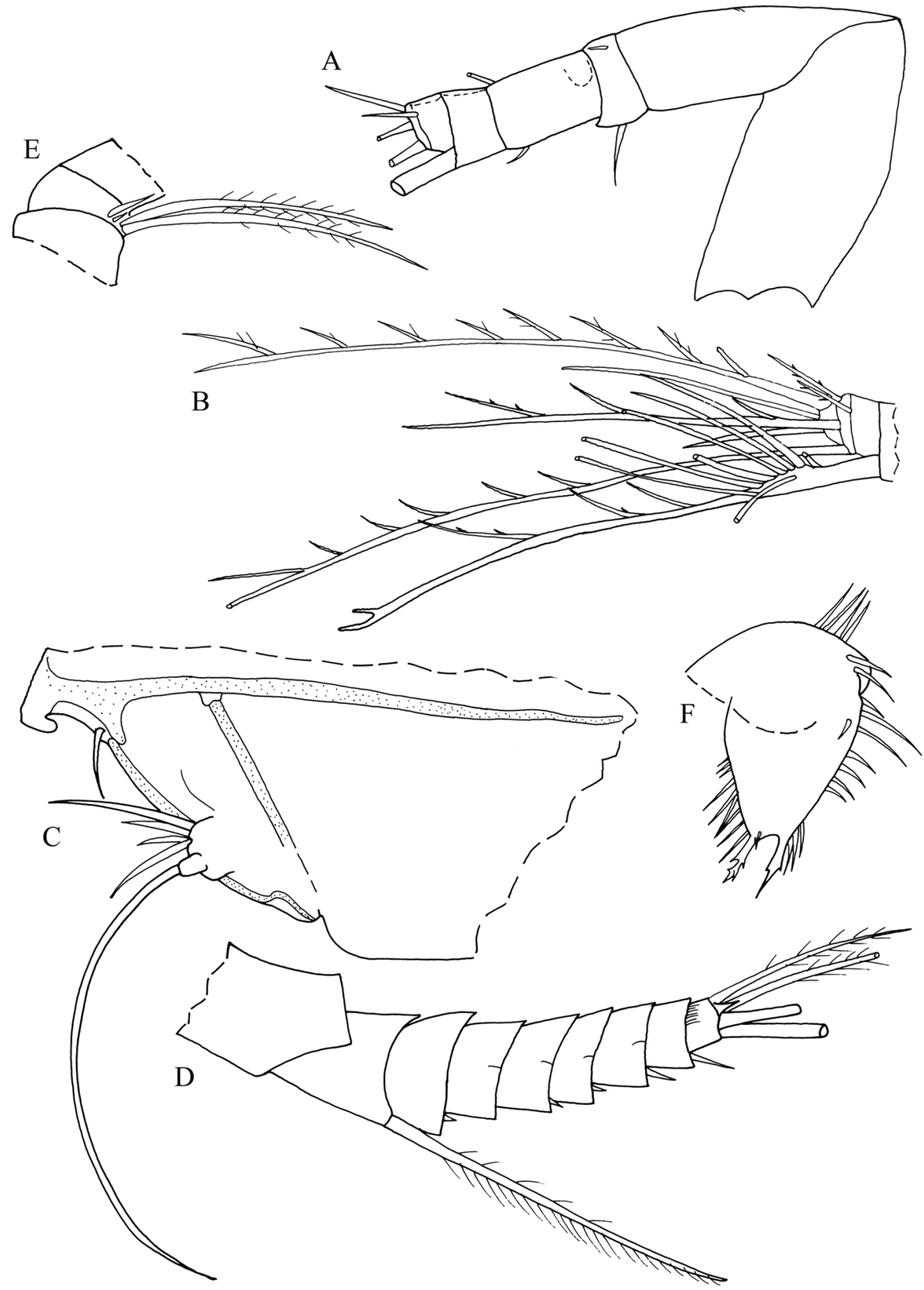

Figure 7. Pterocypridina colesi, holotype, врвм-S 14518, adult female: $A, B$, proximal and distal parts, right 1 st antenna, medial view; $C$, part right 2 nd antenna, medial view; $D$, exopod left 2 nd antenna, lateral view; $E$, bristles of endopod article 1 left mandible, medial view; $F$, coxa endite, left mandible, medial view. 
of holotype with small lateral spine (spine absent on left limb). Articles 5-8 with stout lateral spine near ventral margin. Article 8 with indistinct minute lateral spines along distal edge. Article 9 with lateral spine near dorsal edge.

Mandible (Figures $7 E, F, 8 A, B$ ): Coxa endite spinous; tip with 2 stout spines without peg between them; small ringed bristle on endite near base (Figures $7 F, 8 B$ ). Basis: ventral margin with 2 small medial a-bristles, 1 small lateral b-bristle, 2 small c-bristles, and 1 long stout spinous d-bristle; dorsal margin with 3 long bristles (1 near midlength, 2 terminal) (Figure 8A). Exopod shorter than length of dorsal margin of endopod 1, with spinous tip and 2 subterminal ventral bristles. Endopod: article 1 with 4 ventral terminal bristles (2 long, 1 small, 1 minute) (Figure $7 E$ ). Article 2 slightly curved, with 1 minute indistinct subterminal medial bristle close to ventral margin (not seen with certainty); dorsal margin with 4 long bristles with short marginal spines, 2 shorter bristles (1 proximal, 1 distal), and 2 very short cleaning bristles (proximal of latter bristles with stout marginal spines). Article 3 with 3 stout claws, 3 bristles near ventral margin, and 1 short lateral bristle (latter bristle not shown in Figure $8 A$ ).

Maxilla (Figures $8 C, D, 9 A$ ): Precoxa endite I with 11 bristles; coxa endite II with 5 bristles; coxa endite III with 1 proximal and 8 distal bristles (Figure 8). Dorsal edge of precoxa with filmlike epipod with marginal fringe of long hairs. Coxa with hirsute dorsal bristle. Basis with 1 or 2 terminal bristles. Exopod well developed, hirsute, with 3 bristles (1 subterminal, 2 terminal). Endopod: article 1 with medial spines, triangular terminal ventral tooth, 2 alpha-bristles with long marginal hairs, and 2 beta-bristles (inner bristle with short indistinct spines, outer bristle pectinate); article 2 with 4 a-bristles (inner bristle pectinate), 3 or 4 pectinate b-bristles, 3 pectinate c-bristles, and 3 pectinate d-bristles.

Fifth limb (Figure 9B,C): Epipod with 45 setose bristles. Coxa: endite I with 7 bristles; endite II with 6 bristles; endite III with 7 bristles. Basis: endite I with 1 medial proximal bristle, small medial triangular peg, and 6 stout terminal pectinate teeth. Endite II: lateral side with proximal row composed of small sclerotized tooth and 4 bristles; small d-bristle present near outer edge of distal edge of endite; medial side with long spinous proximal c-bristle; distal end with 4 stout pectinate a-bristles and 6 pectinate $b^{\prime}+b^{\prime \prime}$ bristles. Endopod: article 1 with 3 spinous bristles ( 1 subterminal, 2 terminal); article 2 hirsute, with 6 spinous terminal bristles. Exopod hirsute, with 2 spinous terminal bristles.

Sixth limb (left limb of holotype) (Figure 9D): With 3 or 4 short exopodial bristles. Endite I with 2 short medial and 2 long terminal bristles; endite II with 2 short medial bristles and 2 terminal bristles (1 long, 1 short); endites III and IV each with 1 short medial bristle and 4 terminal bristles (1 short, 3 long). End article with about 21 bristles (16 medium or long, 5 very short); 2 posterior bristles longer than others and plumose (illustrated left limb of holotype aberrant in having 3rd posterior bristle with base on medial side). Right limb of holotype with 26 bristles on end article. Both limbs with areas of black pigment.

Seventh limb (Figure 10A): With 2 articles. Proximal article with about 100 annuli and 7 bristles ( 3 or 4 on each side), each with 4 to 6 bells. Terminal article with 7 bristles on comb side, each with 1 to 6 or 7 bells, and 7 bristles on opposite side, each with 1 to 6 or 7 bells. Comb with about 11 short teeth with square tips on each side of 3 longer teeth with pointed tips, about 25 teeth total. Side opposite comb with 2 small dentate ridges, each with about 10 small teeth along edge.

Furca (Figures $8 E, 10 E$ ): Each lamella with 10 claws; claw 2 fused to lamella; claw 5 very slightly broader than claw 4 . All claws with slender teeth along posterior edge. Claw 1 with fairly stout distal medial tooth. Right lamella anterior to left by width of base of claw 1 .

Bellonci Organ (Figure 6I, 12D,E): Short, pear-shaped.

Eyes: Lateral eye well developed, with about 20 visible divided ommatidia, but others hidden in black pigment (Figures $6 B, \mathcal{F}, 12 D)$. Medial eye about same size as lateral eye, amber colored (Figures 6I, 12D,E).

Upper lip (Figures 10B-D, 12D,F,G): Un- 


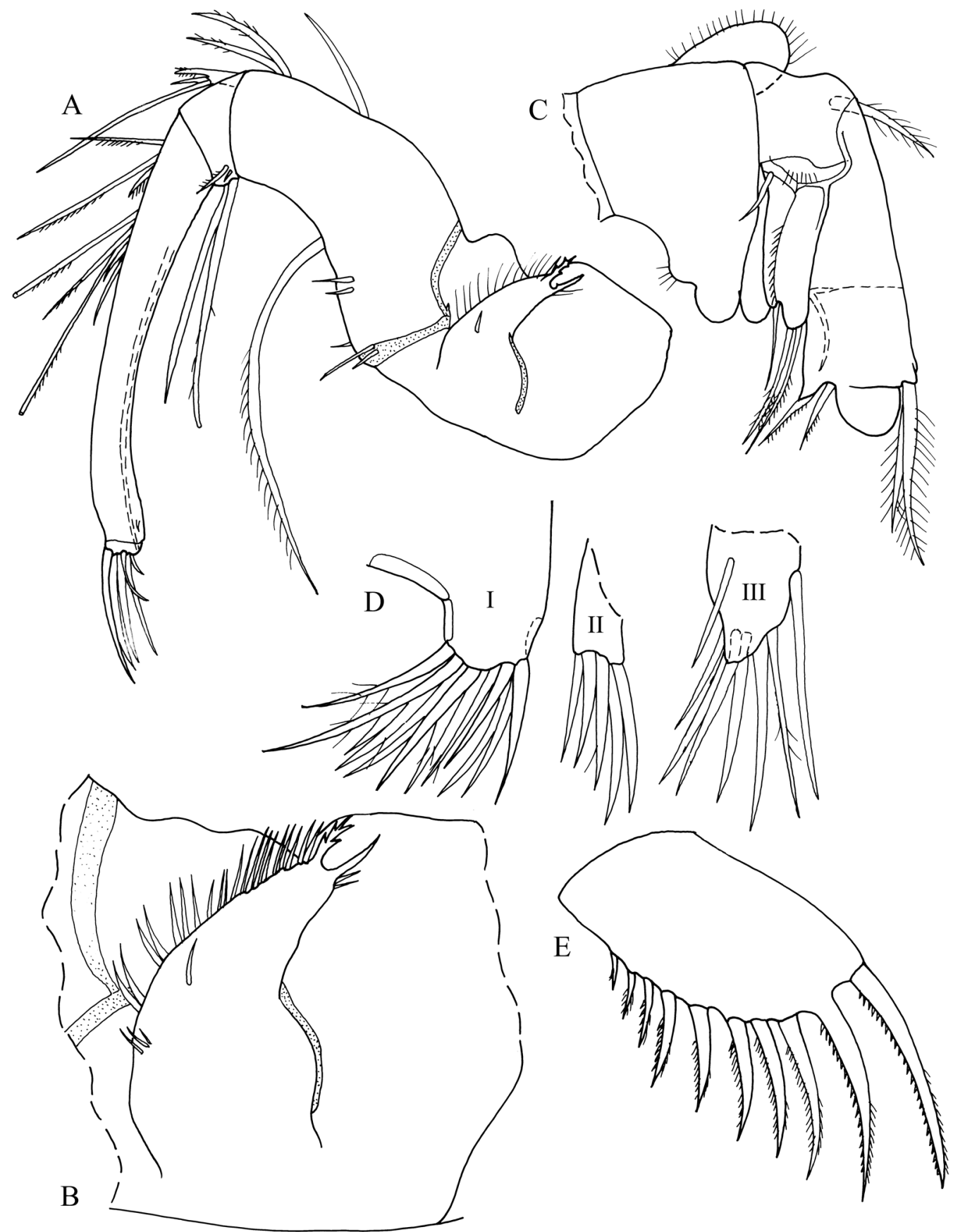

Figure 8. Pterocypridina colesi, holotype, врвм-S 14518, adult female: $A$, right mandible, medial view; $B$, coxa endite, right mandible, medial view; $C$, right maxilla, lateral view (not all bristles shown); $D$, endite left maxilla, lateral view; $E$, right lamella of furca. 

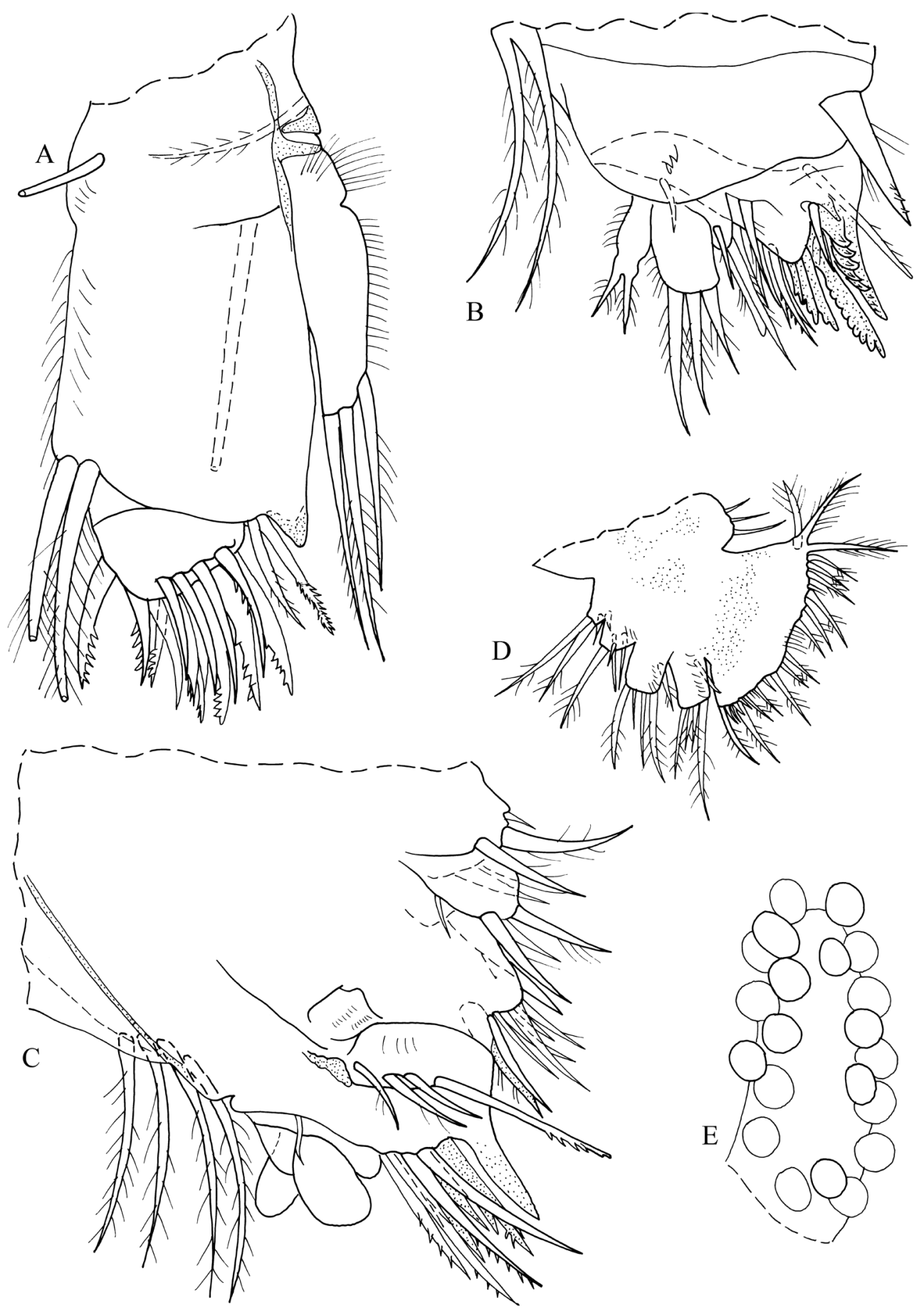

Figure 9. Pterocypridina colesi, holotype, врвм-S 14518, adult female: $A$, part left maxilla, medial view; $B$, part left 5 th limb, medial view; $C$, part right 5 th limb, lateral view (not all bristles shown); $D$, left 6th limb, lateral view; $E$, cluster of eggs removed from inside body. 


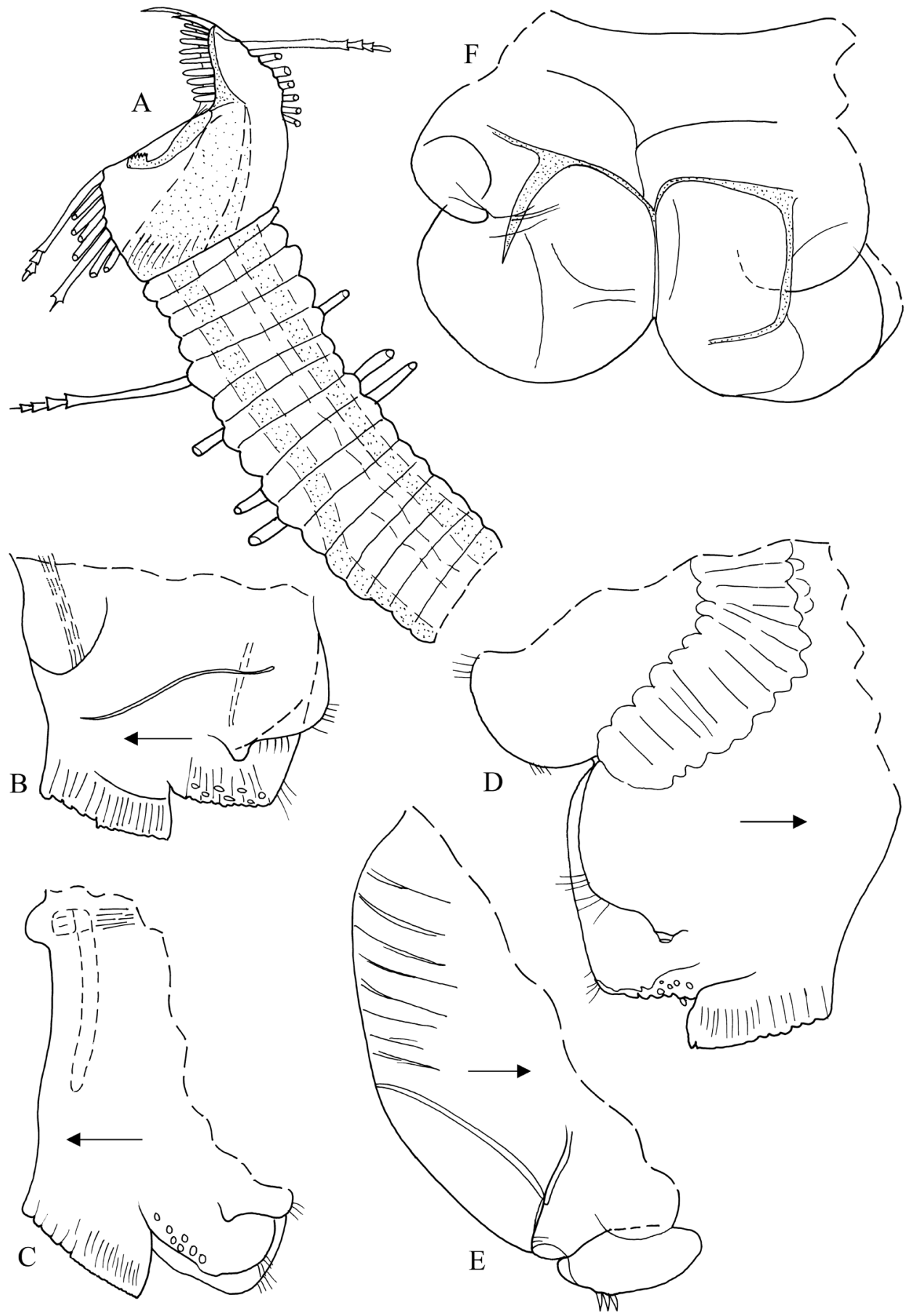

Figure 10. Pterocypridina colesi, holotype, врвм-S 14518, adult female: $A$, 7th limb (distal ends of most bristles not shown); $B, C$, upper lip and anterior of body from left side; $D$, anterior of body including upper lip and esophagus from right side; $E$, posterior of body and furca showing 3 posterior claws; $F$, genitalia. 


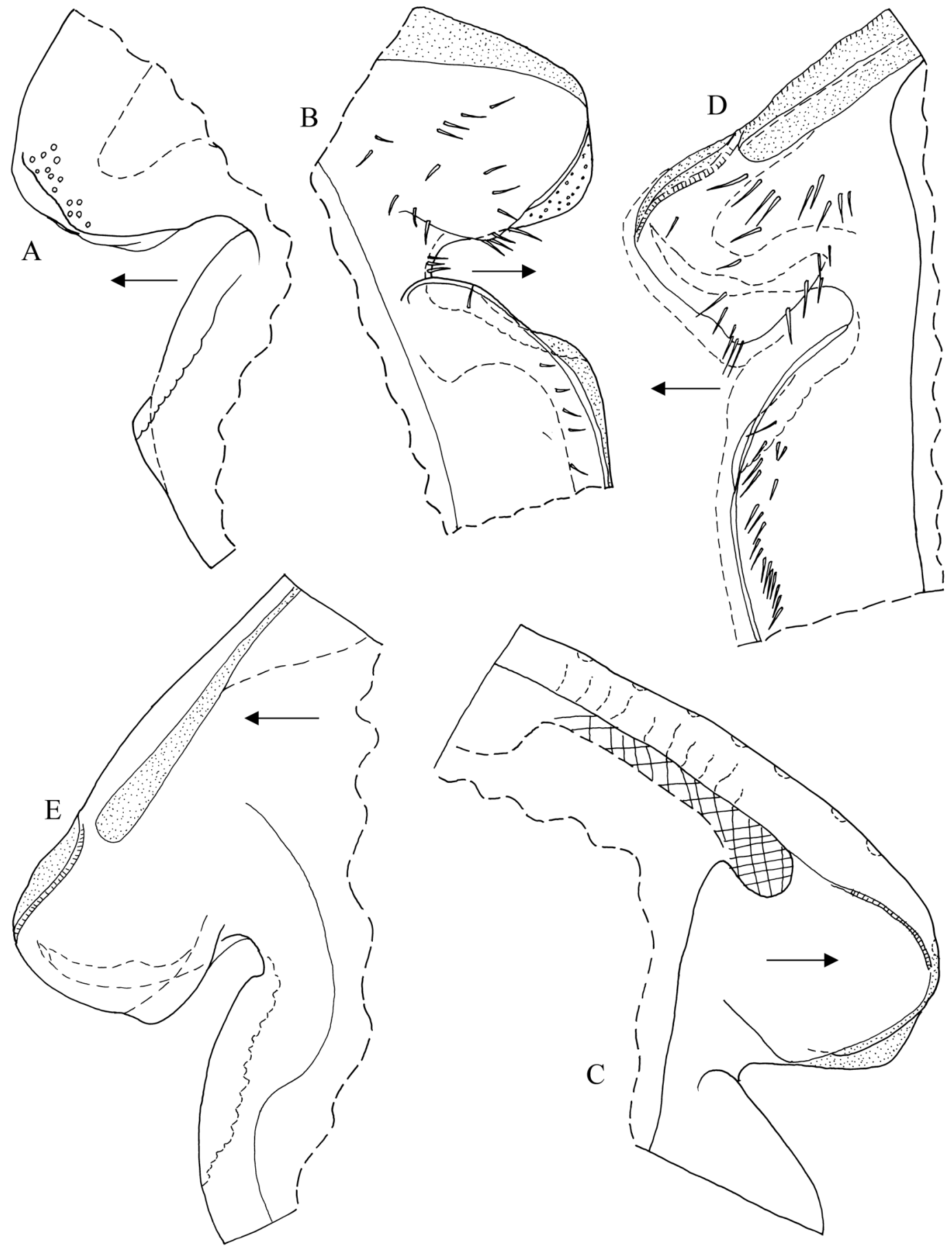

Figure 11. Pterocypridina colesi, paratype, usNm 1121656, adult female, carapace length $2.15 \mathrm{~mm}$, anterior part of valves: $A-C$, left valve; $D, E$, right valve. Internal bristles not shown in $C$ and $E$. 


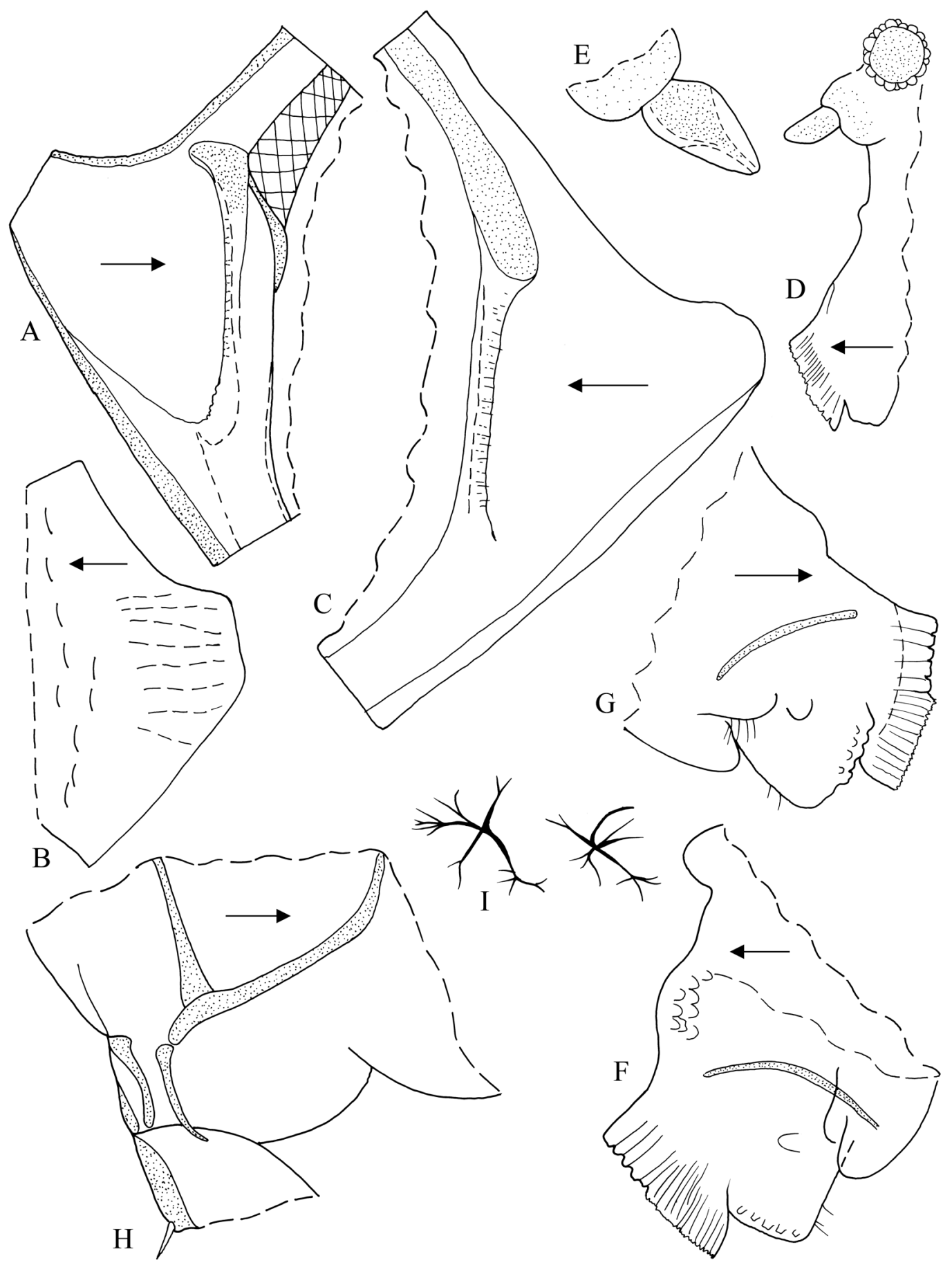

Figure 12. Pterocypridina colesi, paratype, USNM 1121656, adult female: $A, B$, inner and outer views of posterior of left valve; $C$, inner view of posterior of right valve; $D$, anterior of body from left side; $E$, medial eye and Bellonci Organ; $F$, upper lip and anterior of body from left side; $G$, upper lip from right side; $H$, posterior of body from right side (only posterior bristle shown on furca). I, Paratype, врвм-S $14519 \mathrm{~b}$, adult female, carapace length $2.15 \mathrm{~mm}$ : anastomosing chromatophores inside left valve, outside view. 
paired anterior part with ventral edge bearing many small glandular processes; anterior half of anterior part of ventral edge with 5 or 6 stout glandular processes; posterior half of ventral edge projects slightly farther than anterior half and bears many minute processes. Paired posterior part of lip with glandular processes on outer side as well as along terminal edge; long spines present on posterior edge. Spinous lateral flap at posterior end of posterior part of lip; flap with single small lobe with terminal glandular process.

Anterior process (Figures 10C, 12D, G): Rounded knob on anterior of body between Bellonci Organ and upper lip.

Posterior of body (Figures 10E, 12H): Evenly rounded, bare.

Genitalia (Figure 10F): Composed of 2 oval structures.

Y-sclerite (Figures 10E, 12H): Without ventral branch.

DESCRIPTION OF ADULT MALE (Figures 13-17): Carapace oval in lateral view, with prominent rostrum, incisure, and caudal process (Figure 13A,C). Rostrum with small lateral lobe and rounded tip; tip of caudal process linear; narrow crescentlike process extends past valve edge at anteroventral curvature of valve. Dorsal edge of left valve extends past dorsal edge of right valve (Figure $13 C)$.

Ornamentation: Outer surface of valves with small, shallow, rounded fossae (not visible on all specimens) (Figure 13A,C). Curved row of about 16 connected minute serrations extends from inner end of incisure to anterior edge of valve ventral to incisure.

Chromatophores: None observed on 2 specimens examined.

Infold: Not examined.

Selvage: None observed.

Hingement: Similar to that of adult female.

Central adductor muscle attachments: Obscured, but muscle consisting of many oval strands.

Nodules: Specimens in collection with numerous scattered oval nodules within valves.

Carapace size (length, height in $\mathrm{mm}$ ): USNM 1121658, 1.69, 1.05; вРвм-S 14528, $1.79,1.19$.
First antenna (Figure 13D-F): Articles 1 and 2 bare. Article 3 short, with 2 bristles (1 ventral, 1 dorsal). Article 4 with short distal ventral bristle. Sensory bristles of article 5 with 9 long filaments followed by 3 shorter and more slender filaments with few marginal spines; tip of bristle bifurcate. Article 6 with fairly long terminal medial bristle. Article 7: a-bristle slightly shorter than bristle of article 6; b-bristle with short stout proximal filament with large marginal sucker; tip of bristle missing, with 4 slender filaments with spines on remaining part; c-bristle much longer than b-bristle, with short stout proximal filament with sucker slightly larger than that on bbristle, followed by short filament with 3 small suckers, then slender short filament with 4 small suckers (tip of bristle missing). Article 8: d- and e-bristles filamentlike; fand g-bristles with numerous long thin proximal hairs followed by 9 short filaments (some with spines) and bifurcate tip (Figure $13 F$ ).

Second antenna (Figure 13G,H): Protopod without lateral spines near dorsal margin, and with short distal medial bristle (Figure $13 G$ ); protopodial pivot broad (Figure 14A). Endopod with 1 article with 4 anterior bristles ( 3 shorter, 1 long) and very long terminal filament. Exopod (Figure 13H): bristle of 2nd article reaching tip of 9th article, with long hairs on both ventral and dorsal margins; bristles of articles 3-8 long, with natatory hairs (proximal hairs on some bristles shorter, fairly stout, spinelike); 9th article with 4 bristles with natatory hairs, dorsal bristle short. Articles 5-8 with stout lateral spine near ventral margin. Article 9 with lateral spine near dorsal edge.

Mandible (Figure 14B): Coxa endite spinous; tip with 2 stout spines without peg between them; small ringed bristle on endite near midheight. Basis: ventral margin with 2 small medial a-bristles, 1 minute lateral bbristle, 2 small c-bristles, and 1 long stout spinous d-bristle; dorsal margin with 3 bristles (1 near midlength, 2 terminal). Exopod shorter than dorsal margin of endopod 1 , with spinous tip and 2 subterminal ventral bristles. Endopod: article 1 with 4 ventral terminal bristles (2 long, 1 small, 1 minute). Article 2 slightly curved, with 1 minute indistinct sub- 


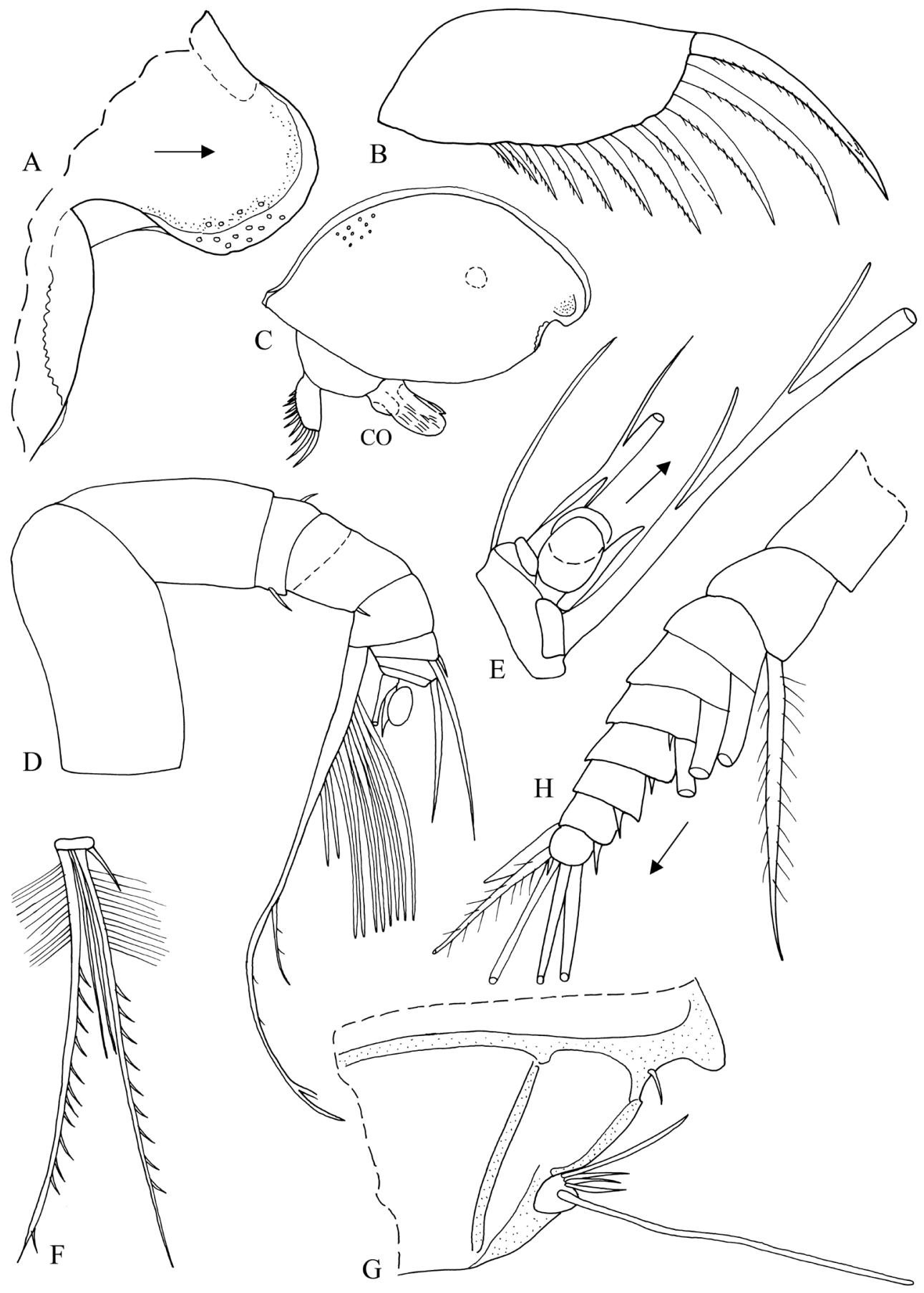

Figure 13. Pterocypridina colesi, paratype, врвм-S 14528, adult male, carapace length $1.79 \mathrm{~mm}: A$, anterior right valve, outside view; $B$, right lamella of furca, outside view. $C-G$, Pterocypridina colesi, paratype, usnm 1121658 , adult male: $C$, complete specimen, length $1.69 \mathrm{~mm} ; D$, left 1st antenna, medial view (not all bristles shown); $E$, tip left 1st antenna, medial view (not all bristles shown); $F$, tip right 1st antenna, lateral view (not all bristles shown); $G$, part protopod and endopod left 2 nd antenna, medial view; $H$, exopod left 2 nd antenna, lateral view (not all bristles shown). 


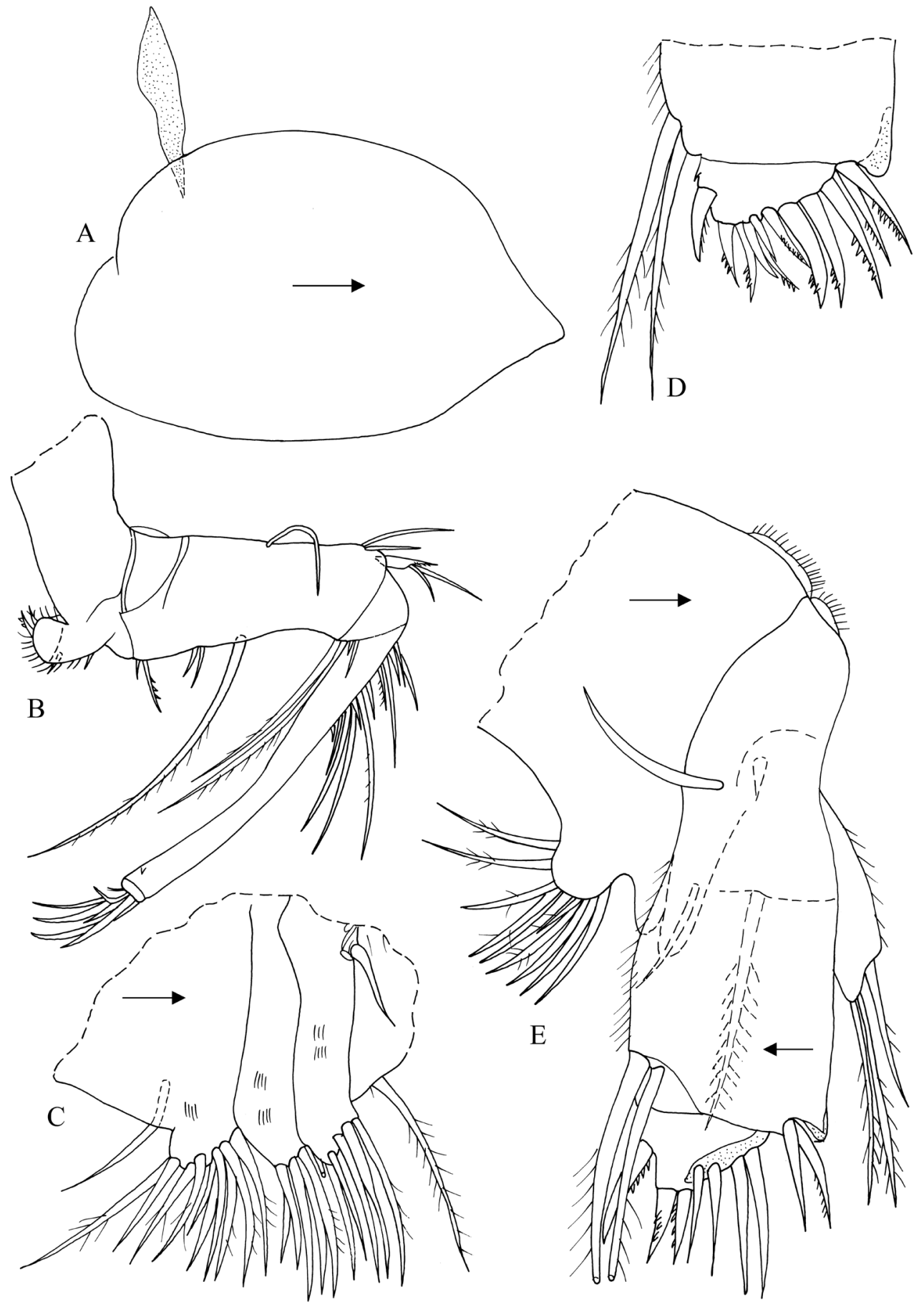

Figure 14. Pterocypridina colesi, paratype, usnm 1121658, adult male: $A$, protopod and pivot (stippled), right 2nd antenna, lateral view; $B$, left mandible, medial view; $C$, endites left maxilla, lateral view; $D$, distal left maxilla, medial view; $E$, right maxilla (twisted: endite lateral view; protopod and exopod medial view). 
terminal medial bristle close to ventral margin (not seen with certainty); dorsal margin with 4 long bristles, some with short marginal spines, 2 shorter bristles (1 proximal, 1 distal), and 6 very short cleaning bristles (3rd bristle from proximal end of latter bristles with stout marginal spines). Article 3 with 3 stout claws, 3 bristles near ventral margin, and 1 short lateral bristle.

Maxilla (Figure $14 C-E$ ): Precoxa endite I with 10 bristles; coxa endite II with 5 bristles; coxa endite III with 1 proximal and 6 distal bristles (Figure 14C,E). Dorsal edges of precoxa and proximal part of coxa with marginal fringe of long hairs. Coxa without hirsute dorsal bristle (possibly broken off). Basis with 2 terminal bristles. Exopod well developed, hirsute, with 3 bristles (1 subterminal, 2 terminal). Endopod: article 1 with medial spines, triangular terminal ventral tooth, 2 alpha-bristles with long marginal hairs, and 2 beta-bristles (lateral inner bristle with short indistinct spines; medial outer bristle pectinate); article 2 with 4 a-bristles (inner bristle pectinate), 3 pectinate b-bristles, 3 pectinate c-bristles, and 3 pectinate d-bristles.

Fifth limb (Figure 15A-C): Epipod fragmented $(35$ setose bristles on remaining part). Coxa: endite I with 7 bristles; endite II with 6 bristles; endite III with 7 bristles. Basis: endite I with 1 medial proximal bristle, small medial triangular peg, and 6 stout terminal pectinate teeth (Figure 15B). Endite II: lateral side with proximal row composed of small sclerotized tooth and 4 bristles; spinous cbristle present on medial side; d-bristle not observed; distal end with 4 stout pectinate a-bristles and 6 pectinate $b^{\prime}+b^{\prime \prime}$ bristles. Endopod: article 1 with 3 spinous bristles (1 subterminal, 2 terminal); article 2 hirsute, with 5 terminal bristles. Exopod hirsute, with 2 spinous terminal bristles.

Sixth limb (Figure 15D): With 3 short exopodial bristles. Endite I with 2 short medial and 2 long terminal bristles; endite II with 2 short medial bristles and 2 terminal bristles (1 long, 1 short); endite III with 1 short medial bristle and 4 terminal bristles (1 short, 3 long); endite IV with 1 short proximal bristle and 5 terminal bristles ( 3 short, 2 long). End article with 18 or 19 bristles (12 or
13 medium or long, 6 very short); 2 posterior bristles longer than others and plumose. Both limbs amber colored, without areas of black pigment.

Seventh limb (Figure 16A,B): With 2 articles. Proximal article with 96 annuli and 9 or 10 bristles ( 4 or 5 on each side), each with 4 to 6 bells. Terminal article with 7 bristles on comb side, each with 1 to 7 bells, and 8 bristles on opposite side, each with 1 to 7 bells. Comb with about 12 short teeth with square tips on each side of 3 longer teeth with pointed tips, about 27 teeth total (not all shown in illustrated limb). Side opposite comb with 2 small dentate ridges, each with about 4 to 7 small teeth along edge.

Furca (Figure 16C): Each lamella with 10 claws; claw 2 fused to lamella; claw 5 about same width and length as claw 4 or slightly wider. All claws with slender teeth along posterior edge. Claw 1 with fairly stout distal medial tooth. Right lamella anterior to left by width of base of claw 1 .

Bellonci Organ (Figure 16E,F): Short, oval.

Eyes: Lateral eye well developed, with about 25 visible divided ommatidia, but others hidden in black pigment (Figures $13 C, 16 E)$. Medial eye about same size as lateral eye, amber colored (Figure 16E,F).

Upper lip (Figure 17): Unpaired anterior part with ventral edge bearing many small glandular processes; anterior half of anterior part of ventral edge with 5 or 6 stout glandular processes; posterior half of ventral edge does not project past ventral margin of anterior half and bears 7 narrower glandular processes. Paired posterior part of lip with glandular processes on outer side as well as along terminal edge; posterior edge bare. Spinous lateral flap at posterior end of posterior part of lip; flap with several indistinct spinelike processes.

Anterior process (Figure 17C): Rounded knob on anterior of body between Bellonci Organ and upper lip.

Posterior of body (Figure 16C): Posterodorsal margin with 3 small indentations, bare.

Genitalia (Figures 13C, 16C,D): Composed of 2 large copulatory organs.

Y-sclerite (Figure 16C): With small ventral branch. 


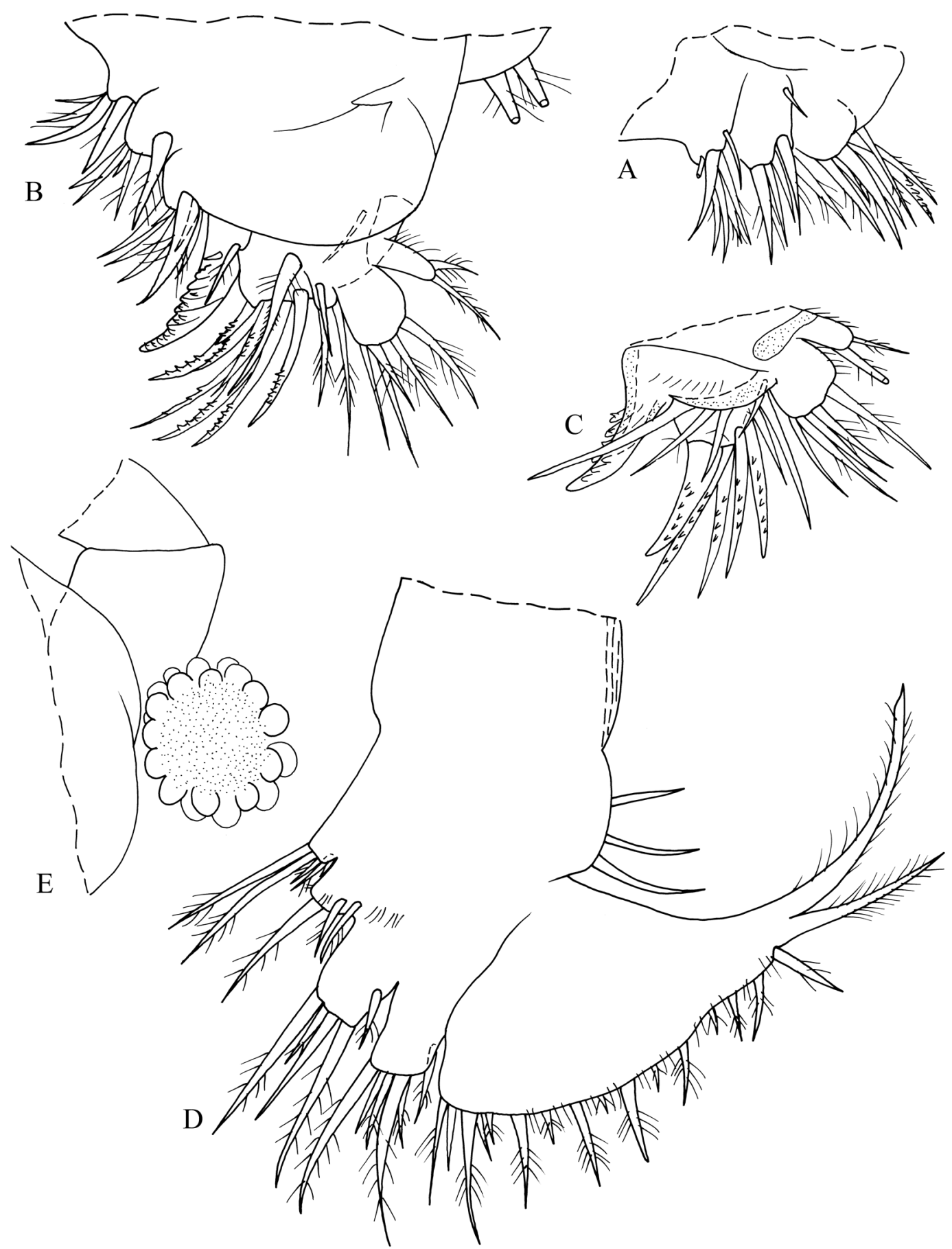

Figure 15. Pterocypridina colesi, paratype, usnm 1121658, adult male: $A$, left 5th limb, lateral view; $B$, right 5 th limb; $C$, left 5 th limb; $D$, left 6 th limb, lateral view; $E$, anterodorsal part of body with left valve removed (proximal left 1 st antenna, posterior edge protopod left 2 nd antenna, left lateral eye). 


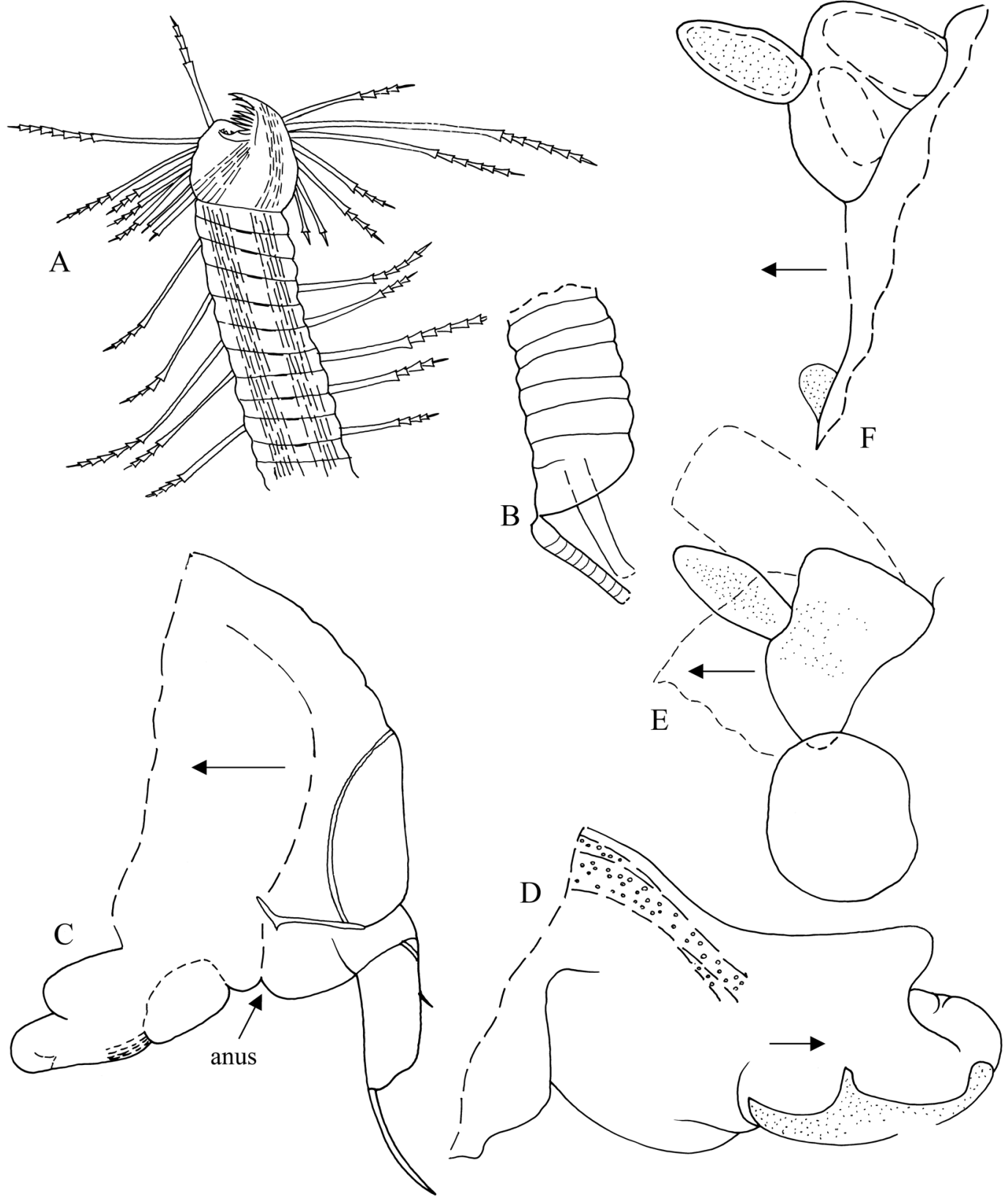

Figure 16. Pterocypridina colesi, paratype, USNM 1121658, adult male: $A, B$, tip and base of 7 th limb; $C$, posterior of body from left side, only 2 claws shown on furca; $D$, copulatory organ from right side; $E$, anterodorsal part of body showing 1st antenna (dashed), medial eye and Bellonci Organ (stippled), and outline of left lateral eye; $F$, anterior of body showing medial eye and Bellonci Organ and anterior process. 


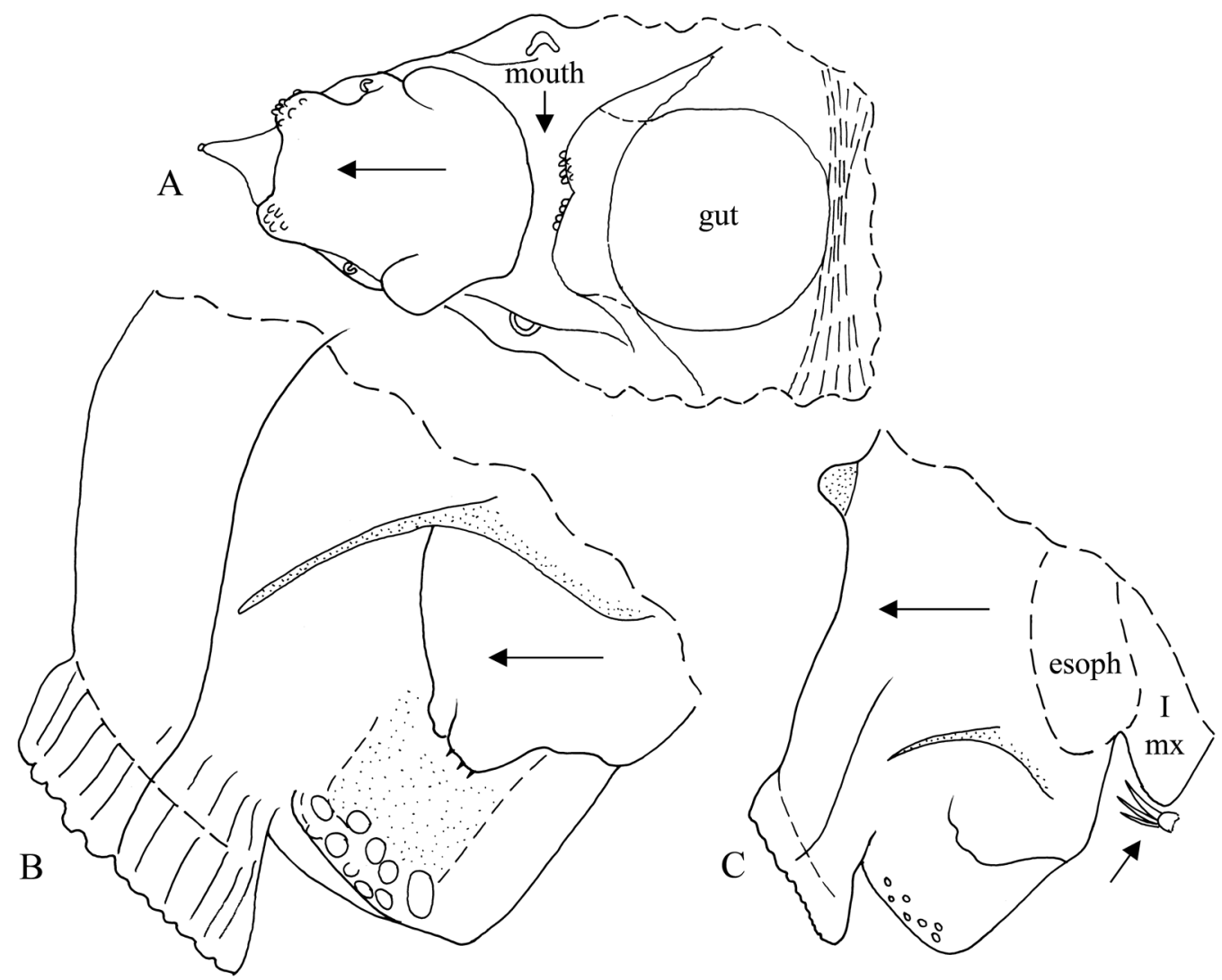

Figure 17. Pterocypridina colesi, paratype, usNm 1121658, adult male: $A$, ventral view of anterior of body showing upper lip, mouth, part of gut, and central adductor muscle; $B$, upper lip from left side; $C$, anterior part of body from left side showing upper lip and anterior process (arrow indicates 3 bristles on endite of maxilla).

DESCRIPTION OF INSTAR I (Figures 18, 19): Carapace oval in lateral view, with prominent rostrum, incisure, and caudal process (Figure 18A,B). Rostrum with small lateral lobe and rounded tip; tip of caudal process rounded.

Ornamentation: Outer surface of valves appearing smooth. Curved line without serrations extends from inner end of incisure almost to anterior edge of valve ventral to incisure (Figure 18A). body.

Chromatophores: None visible in shell or

Infold: Similar to that of adult female but with fewer bristles.

Selvage: Similar to that of adult female.
Hingement: Similar to that of adult female.

Central adductor muscle attachments: With oval attachments.

Nodules: Specimens in collection with numerous scattered oval nodules within valves.

Carapace size (length, height in $\mathrm{mm}$ ): USNM 1121840, 0.66, 0.39; USNM 1121841, $0.68,0.38$.

First antenna (Figure 18B,C,H): Articles 1 and 2 bare. Article 3 short, with 2 bristles (1 ventral, 1 minute dorsal). Article 4 without distal dorsal bristle. Articles 4 and 5 fused. Sensory bristles of article 5 ringed, bare. Article 6 with short terminal medial spinous bristle. Article 7: a-bristle about same length 


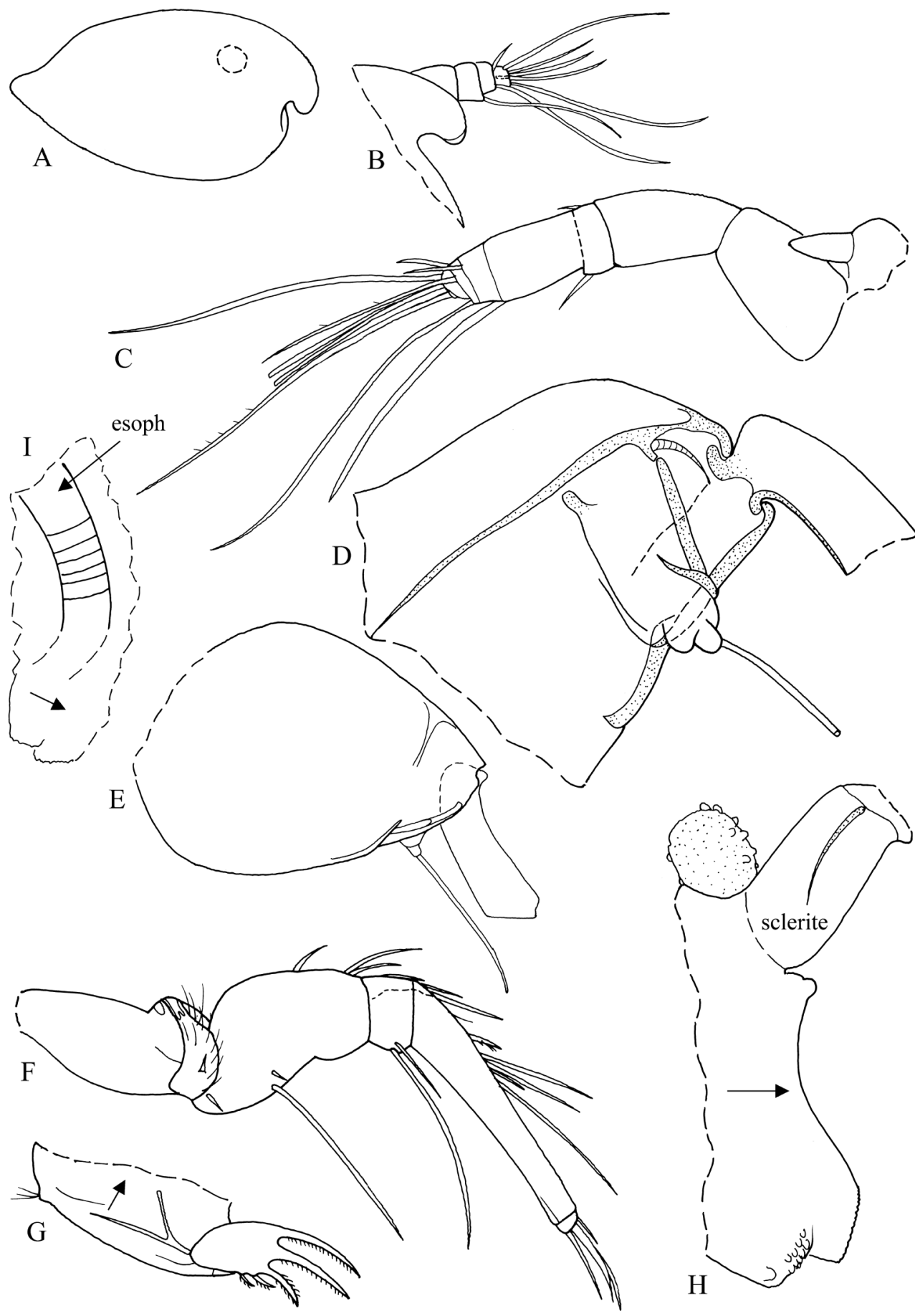

Figure 18. Pterocypridina colesi, paratype, usNm 1121840, instar I: $A$, complete specimen from right side, length 0.66 $\mathrm{mm} ; B$, anterior of specimen showing projecting right 1st antenna; $C$, anterior of body showing right $2 \mathrm{nd}$ antenna (medial view), medial eye, and Bellonci Organ; $D$, part left 2nd antenna, medial view; E, part right 2nd antenna (exopod twisted), lateral view; $F$, left mandible, medial view; $G$, posterior of body including right lamella of furca; $H$, anterior of body showing right lateral eye, anterior process, upper lip, and article 1 of right 1st antenna; $I$, part of body from right side showing internal esophagus and part of lower lip at bottom. 
as bristle of article 6; b-bristle with 2 minute marginal spines; c-bristle much longer than b-bristle, with about 5 minute marginal spines. Article 8: d- and e-bristles filamentlike, same length as b-bristle; f-bristle about same length as c-bristle, with about 2 marginal spines; g-bristle about same length as c-bristle, with about 5 marginal spines.

Second antenna (Figure 18D,E): Protopod with short distal medial bristle (Figure 18D). Endopod with 2 articles: article 1 bare; article 2 short, with long terminal filament. Exopod: bristle of 2 nd article reaching 8 th article, with slender spines; bristle of article 3 with slender spines thinner near tip; bristles of articles 5-8 with natatory hairs; 9th article with 2 bristles: ventral bristle long with natatory hairs, dorsal bristle short, bare. Article 9 with small lateral spine.

Mandible (Figure 18F): Coxa endite spinous, with bifurcate tip with small process between bifurcation; small proximal bristle present. Basis: ventral margin with 1 small medial a-bristle, 1 small c-bristle, and 1 long adjacent d-bristle; dorsal margin with 3 bristles ( 1 near midlength, 2 terminal). Exopod slightly longer than dorsal margin of article 1 of endopod, with 2 terminal bristles. Article 1 with 2 ventral bristles (1 long, 1 short). Article 2 slightly curved, without ventral bristles; dorsal margin with 5 bristles ( 3 long, 2 short). Article 3 with 2 stout claws, 1 long ringed clawlike bristle near ventral margin, and 1 short bristle on dorsal corner.

Maxilla (Figure $19 A-C$ ): Precoxa endite I with 6 bristles; coxa endite II with 5 bristles; coxa endite III with 1 proximal and 4 distal bristles (Figure 19A). Dorsal edge of precoxa with narrow filmlike epipod with marginal hairs. Coxa with short hirsute dorsal bristle. Basis with 2 terminal bristles. Exopod well developed, hirsute, with 3 bristles (1 subterminal, 2 terminal). Endopod: article 1 with medial spines, triangular terminal ventral tooth, 1 alpha-bristle with long marginal hairs, and 1 beta-bristle; article 2 with 2 stout claws and 3 bristles.

Fifth limb (Figure 19D-F): Epipod with setose bristles. Coxa: endite I with 2 bristles; endite II with 4 bristles; endite III with 4 bristles. Basis: endite I with 1 medial proximal bristle, 1 short distal bristle, and 1 stout terminal pectinate tooth (Figure 19D); endite II: lateral side with stout terminal elongate sclerotized pectinate bristle and 1 proximal bristle; medial side with long spinous proximal c-bristle (Figure 19D). Endopod: article 1 with 1 stout terminal tooth and 1 or 2 slender bristles; article 2 hirsute, with 1 proximal and 2 terminal bristles. Exopod hirsute, with 2 spinous terminal bristles.

Sixth limb (Figure 19G): With marginal spines, no bristles.

Seventh limb: Not observed.

Furca (Figure 18G): Each lamella with 5 claws; claws 2-5 fused to lamella; claw 2 broader than claw 1; claw 4 about same width and length as claw 3. All claws with slender teeth along posterior edge. Claw 1 with fairly stout distal medial tooth. Right lamella anterior to left by width of base of claw 1.

Bellonci Organ (Figure 18C): Tapering to point.

Eyes: Lateral eye well developed, with few visible divided ommatidia along edge but others hidden in black pigment (Figure $18 A, H)$. Medial eye present (Figure 18C).

Upper lip (Figure 18H,I, 19H): Unpaired anterior part with ventral edge bearing many small glandular processes. Paired posterior part of lip with glandular processes on outer side as well as along terminal edge; long spines present on posterior edge. Lateral flap at posterior end of posterior part of lip.

Anterior process (Figure 18H): Rounded knob on anterior of body between Bellonci Organ and upper lip.

Posterior of body (Figure 18G): Evenly rounded, with tuft of hair on posterodorsal corner.

Genitalia: Absent.

Y-sclerite (Figure 18G): Without ventral branch.

Gut content: Unrecognized particulate matter.

DESCRIPTION OF INSTAR II (Figures 20, 21): Carapace oval in lateral view, with prominent rostrum, incisure, and caudal process (Figure 20A). Rostrum with small lateral lobe and rounded tip; tip of caudal process linear or slightly rounded. 

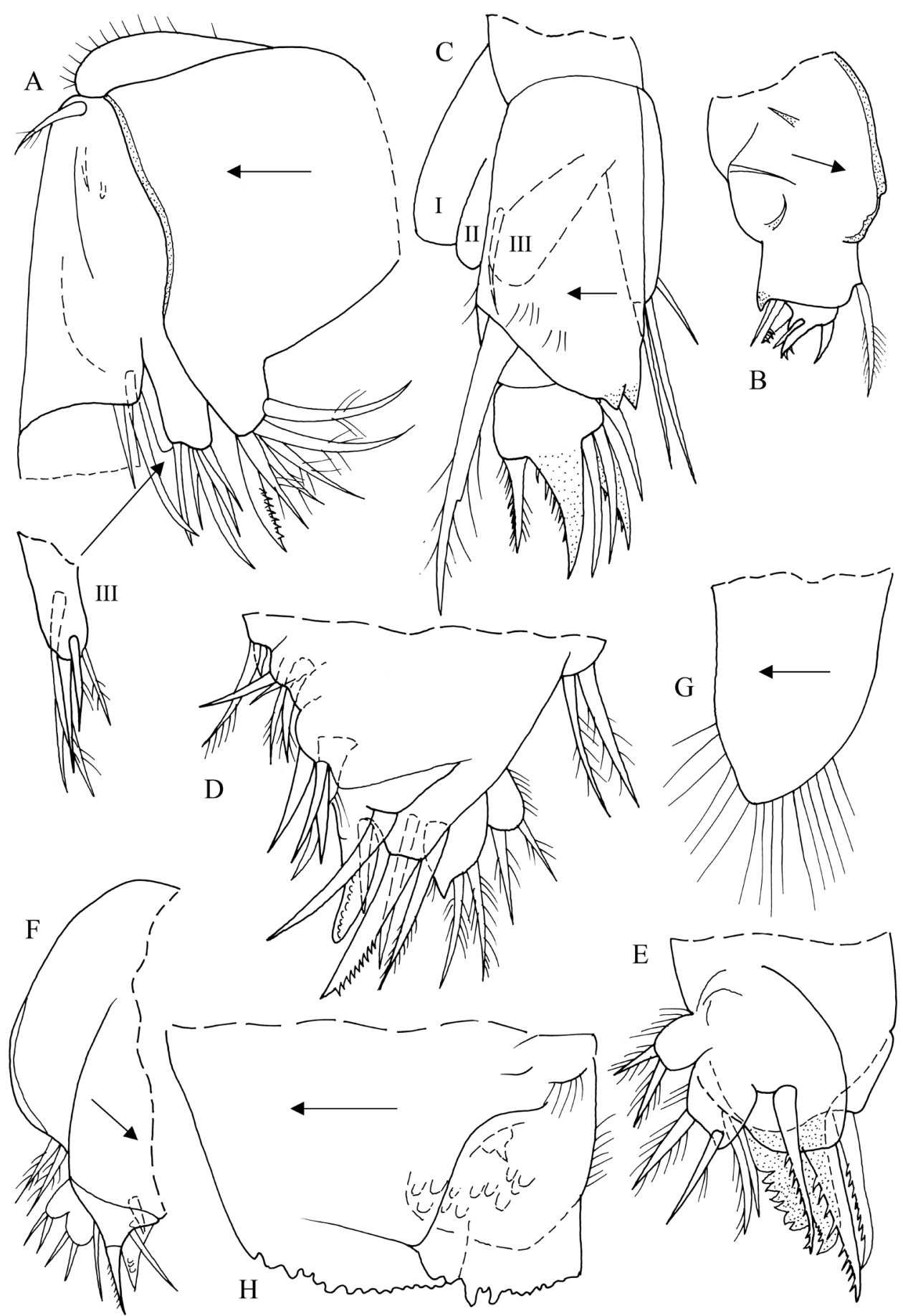

Figure 19. Pterocypridina colesi, paratype, USNm 1121840, instar I: $A$, part right maxilla, medial view; $B$, right maxilla drawn on body, lateral view (not all bristles shown); $C$, part twisted left maxilla, lateral view (not all bristles shown); $D$, left 5 th limb, lateral view; $E$, part right 5 th limb, lateral view; $F$, right 5 th limb drawn on body, lateral view (not all bristles shown); $G$, left 6th limb, lateral view; $H$, lower lip (squashed under cover slip). 


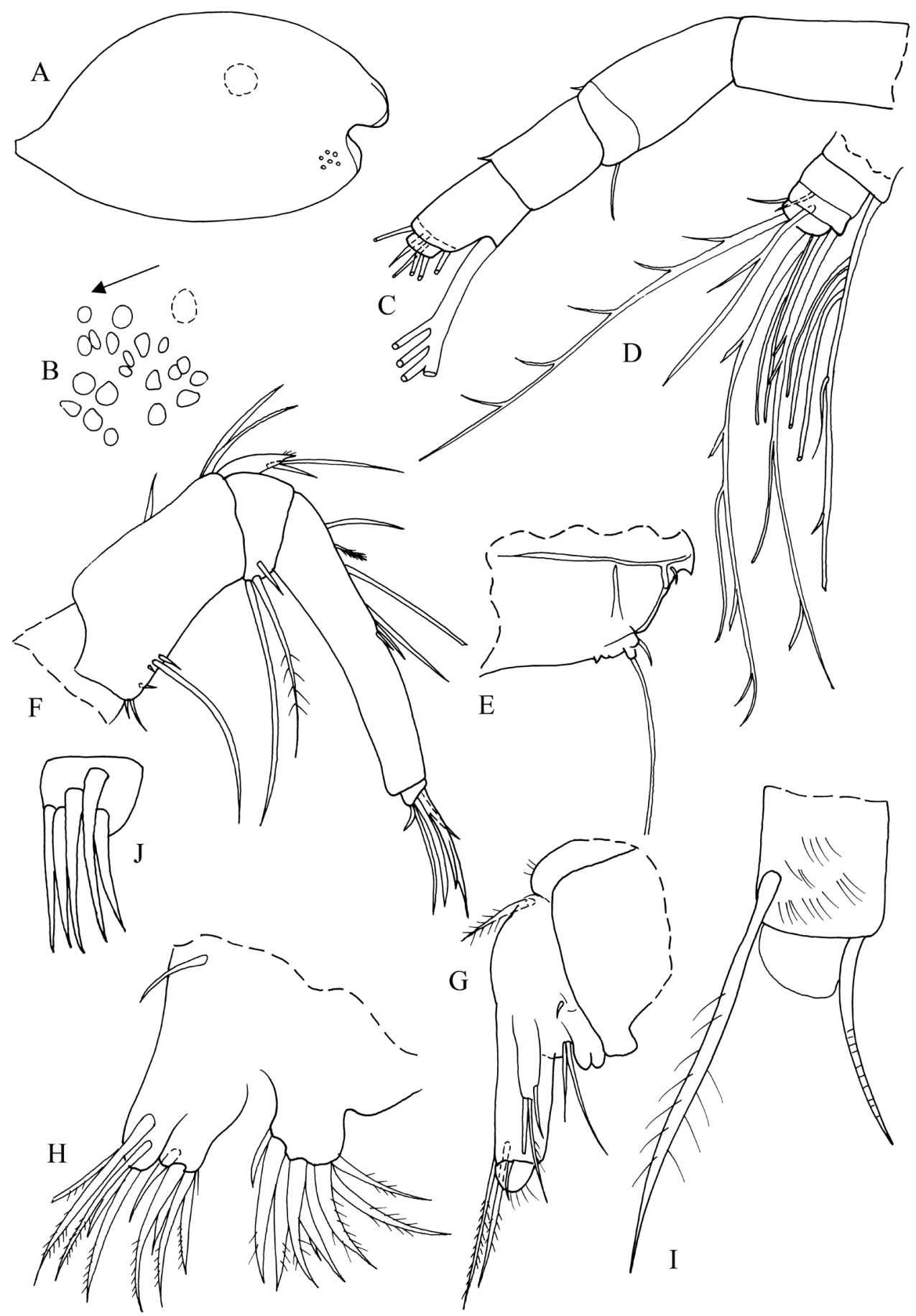

Figure 20. Pterocypridina colesi, paratype, врвм-S 14522, instar II: $A$, complete specimen from right side, length 0.77 $\mathrm{mm} ; B$, central adductor muscle attachments right valve, inside view; $C, D$ (part projecting from between valves), left 1 st antenna, lateral view; $E$, part left 2 nd antenna, medial view; $F$, left mandible, medial view; $G$, left maxilla (twisted, not all bristles shown); $H$, endites left maxilla from $G$, lateral view; $I$, tip endopod left maxilla, medial view (not all bristles shown); $\mathcal{F}$, endopod article 2 left maxilla shown in $G$ (not all bristles shown). 
Ornamentation: Outer surface of valves with indistinct small, shallow, rounded fossae (not visible on all parts of specimens) (Figure $20 A$ ). Curved line without serrations extends from inner end of incisure to anterior edge of valve ventral to incisure (Figure 20A).

Chromatophores: None visible in shell. A few small black spots on body.

Infold: Similar to that of adult female but with fewer bristles, Rostral infold with 7 bristles.

Selvage: Similar to that of adult female.

Hingement: Similar to that of adult female.

Central adductor muscle attachments (Figure 20B): About 20 oval attachments.

Nodules: Specimens in collection with numerous scattered oval nodules within valves.

Carapace size (length, height in $\mathrm{mm}$ ): врвм-S 14522, 0.77, 0.44 .

First antenna (Figure 20C,D): Articles1 and 2 bare. Article 3 short, with 2 bristles (1 ventral, 1 dorsal and minute). Article 4 with 1 minute distal dorsal bristle. Articles 5 and 6 fused. Sensory bristle of article 5 with 3 long, stout proximal filaments and 2 shorter and more slender distal filaments. Article 6 with short terminal medial bristle with few minute marginal spines. Article 7: a-bristle about same length as bristle of article 6; b-bristle with 1 proximal marginal filament; c-bristle much longer than b-bristle, with 4 marginal filaments. Article 8: d- and e-bristles filamentlike, slightly shorter than b-bristle; fbristle about same length as c-bristle, with about 5 marginal filaments; g-bristle about same length as c-bristle, with about 5 marginal filaments.

Second antenna (Figure 20E): Protopod with short distal medial bristle. Endopod with 2 articles: article 1 with 1 anterior bristle; article 2 short, with long terminal filament. Exopod bristle of 2 nd article reaching 8th article, with few spines; bristles of articles 3 and 4 with ventral spines and distal natatory hairs; bristles of articles 5-8 with natatory hairs (proximal hairs on some bristles shorter, fairly stout, spinelike); 9th article with 3 bristles: ventral bristle long with natatory hairs, middle bristle short with few hairs, dorsal bristle very short, bare. Articles 5-8 with small lateral spine near ventral margin. Article 9 with lateral spine near dorsal edge.

Mandible (Figure 20F): Coxa endite spinous; tip not observed. Basis: ventral margin with 2 small medial a-bristles, 1 small lateral b-bristle, 1 small c-bristle, and 2 d-bristles (1 long stout spinous, 1 short and distal to long bristle); dorsal margin with 3 bristles (1 near midlength, 2 terminal). Exopod about same length as dorsal margin of endopod 1, with spinous tip and 2 subterminal ventral bristles. Endopod: article 1 with 3 ventral bristles (2 long, 1 short). Article 2 slightly curved, without ventral bristles; dorsal margin with 3 long bristles, 1 shorter bristle, and 2 very short cleaning bristles (proximal of latter bristles with stout marginal spines). Article 3 with 3 stout claws, 2 bristles near ventral margin, and 1 short lateral bristle.

Maxilla (Figure 20G-7): Precoxa endite I with 8 bristles; coxa endite II with 5 bristles; coxa endite III with 1 proximal and 5 distal bristles (Figure 20H). Dorsal edge of precoxa with filmlike epipod with marginal fringe of few long hairs. Coxa with hirsute dorsal bristle. Basis with 2 terminal bristles. Exopod well developed, hirsute, with 3 bristles (1 subterminal, 2 terminal). Endopod: article 1 with medial spines, triangular terminal ventral tooth, 1 or 2 alpha-bristles with long marginal hairs, and 1 beta-bristle; bristles of article 2 obscured, about 8 bristles visible.

Fifth limb (Figure 21 $A, B$ ): Epipod with setose bristles. Coxa: endite I with 5 bristles; endite II with 5 bristles; endite III with 7 bristles. Basis: endite I with 1 medial proximal bristle, 1 minute distal bristle, and 2 stout terminal pectinate teeth (Figure $21 A$ ). Endite II: lateral side with proximal row composed of elongated sclerotized tooth and 4 bristles including small d-bristle present near outer edge of distal edge of endite (Figure $21 B$ ); medial side with long spinous proximal cbristle (Figure 21 $A$ ); distal end with 3 stout pectinate a-bristles and 4 pectinate $\mathrm{b}^{\prime}+\mathrm{b}^{\prime \prime}$ bristles. Endopod: article 1 with 3 spinous bristles ( 1 subterminal, 2 terminal); article 2 hirsute, with 3 spinous terminal bristles. Exopod hirsute, with 2 spinous terminal bristles. 

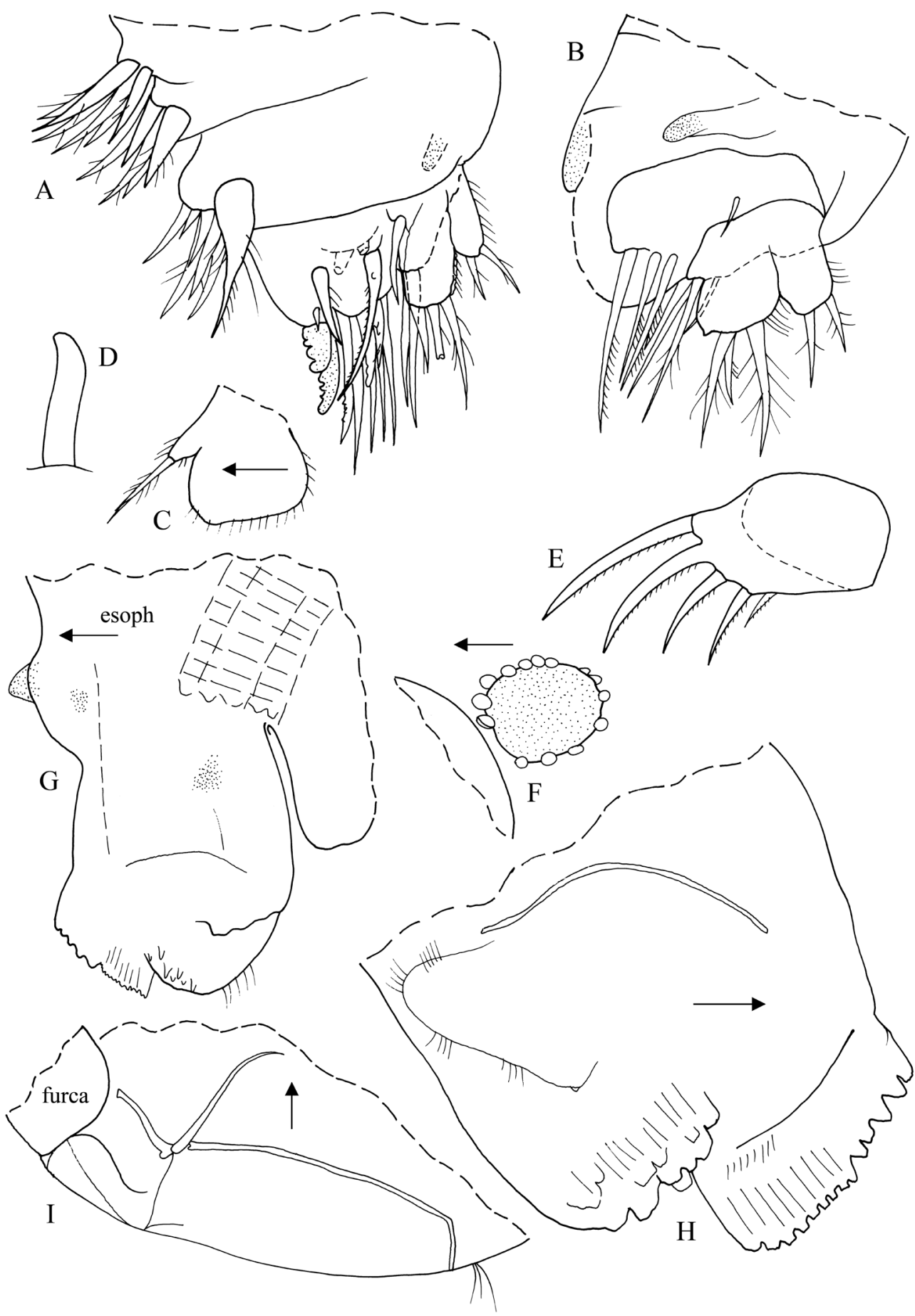

Figure 21. Pterocypridina colesi, paratype, врвм-S 14522, instar II: $A$, right 5 th limb, medial view (not all bristles shown); $B$, left 5th limb, lateral view (not all bristles shown); $C$, left 6th limb drawn on body, lateral view; $D$, left 7th limb, lateral view; $E$, left lamella of furca (part of furca projecting from valves); $F$, left lateral eye and posterodorsal edge of protopod of left 2nd antenna; $G$, anteroventral part of body from left side showing upper and lower lips, anterior process, and internal esophagus; $H$, upper lip from right side; $I$, posterior of body from left side. 
Sixth limb (Figure 21C): Single endite with 1 spinous terminal bristle. End article with marginal spines.

Seventh limb (Figure 21D): Fingerlike, bare, unsegmented.

Furca (Figure 21E): Each lamella with 5 claws; claw 2 fused to lamella and broader than claw 1; claw 4 about same width and length as claw 3 . All claws with slender teeth along posterior edge. Claw 1 with fairly stout distal medial tooth. Right lamella anterior to left by width of base of claw 1 .

Bellonci Organ: Fragmented.

Eyes: Lateral eye well developed, with about 14 visible divided ommatidia along edge but others hidden in black pigment (Figure $21 F$ ). Medial eye fragmented.

Upper lip (Figure 21G,H): Unpaired anterior part with ventral edge bearing many small glandular processes; anterior half of anterior part of ventral edge with 5 stout glandular processes; posterior half of ventral edge projects slightly farther than anterior half and bears 9 minute processes. Paired posterior part of lip with about 12 glandular processes on outer side as well as along terminal edge; long spines present on posterior edge. Lateral flap at posterior end of posterior part of lip; flap with single small lobe with terminal glandular process.

Anterior process (Figure 21G): Rounded knob on anterior of body between Bellonci Organ and upper lip.

Posterior of body (Figure 21I): Evenly rounded, bare.

Genitalia: Absent.

Y-sclerite (Figure 21I): Without ventral branch.

Gut content: Unrecognized particulate matter.

DESCRIPTION OF INSTAR III (Figures 22, 23): Carapace oval in lateral view, with prominent rostrum, incisure, and caudal process (Figure 22A). Rostrum with small lateral lobe and rounded tip; tip of caudal process linear. Dorsal edge of left valve extends past dorsal edge of right valve.

Ornamentation: Outer surface of valves with small, shallow, rounded fossae (not visible on all specimens) (Figure 22A). Nonserrate line extends from inner end of incisure to anterior edge of valve ventral to incisure (Figure 22A).

Chromatophores: Few present on specimen examined.

Infold: Not examined.

Selvage: None observed.

Hingement: Similar to that of adult female.

Central adductor muscle attachments: Obscured.

Nodules: None observed.

Carapace size (length, height in $\mathrm{mm}$ ): врвм-S 14728, 0.99, 0.65.

First antenna (Figure 22B): Articles 1 and 2 bare. Article 3 short, with 2 short marginal bristles ( 1 ventral, 1 dorsal). Article 4 with 2 short terminal bristles (1 ventral, 1 dorsal). Sensory bristle of article 5 with 4 long filaments followed by 3 shorter and more slender filaments, with few marginal spines; tip of bristle bifurcate. Article 6 with fairly long terminal medial bristle. Article 7: a-bristle about same length as bristle of 6th article; b-bristle long with 2 short filaments; c-bristle longer than bristle of 5 th article, with 5 slender distal filaments. Article 8: d- and e-bristles filamentlike; f- and $\mathrm{g}$-bristles long with several filaments.

Second antenna (Figure 22C,D): Protopod without lateral spines near dorsal margin, and with short distal medial bristle (Figure 22C); protopodial pivot broad. Endopod: article 1 with 2 short anterior bristles; fused minute article 2 with 1 long terminal filament. Exopod: bristle of 2 nd article reaching to about 8th article, margins obscured, marginal hairs not observed; bristles of articles 3-8 long, with natatory hairs; 9th article with 3 bristles with natatory hairs, dorsal bristle short. Article 9 with lateral spine.

Mandible (Figure 22E): Coxa endite spinous; tip with 2 stout spines without peg between them; small bristle on endite near base. Basis: ventral margin with 2 small medial a-bristles, 1 minute lateral b-bristle, 2 small c-bristles, and 1 short and 1 long, stout spinous d-bristle; dorsal margin with 3 bristles (1 near midlength, 2 terminal). Exopod about same length as dorsal margin of endopod 1, with spinous tip and 2 subterminal ventral bristles. Endopod: article 1 with 3 ventral 


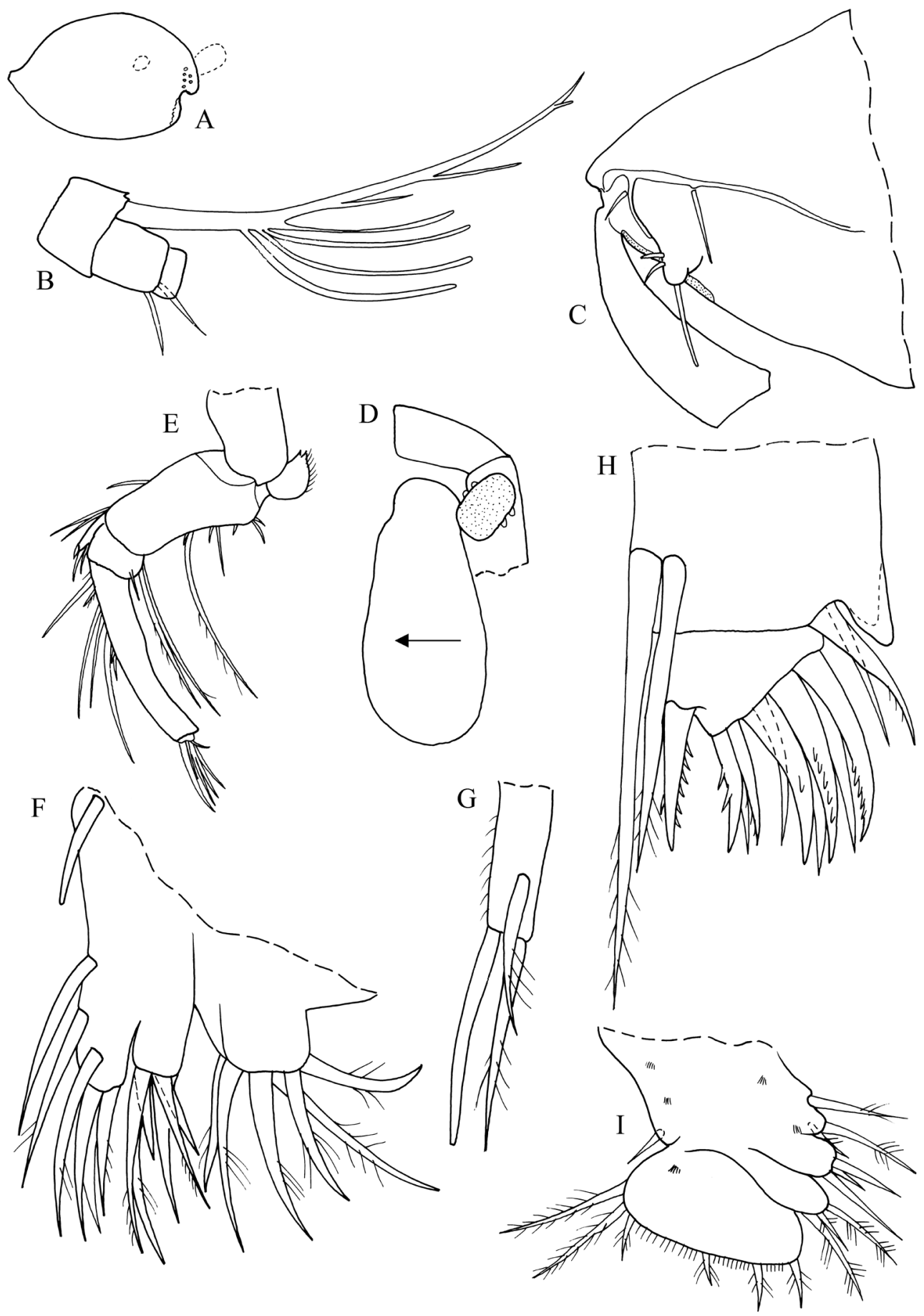

Figure 22. Pterocypridina colesi, paratype, врвм-S 14728, instar III: $A$, complete specimen from right side, length 0.99 $\mathrm{mm} ; B$, left first antenna, articles 5-8, lateral view (not all bristles shown; articles 7 and 8 fused); $C$, part right $2 \mathrm{nd}$ antenna, medial view; $D$, anterodorsal part of body showing protopod left 2 nd antenna, articles 1 and 2 left 1 st antenna, and left lateral eye, lateral view; $E$, right mandible, medial view; $F$, endites left maxilla, lateral view; $G$, exopod left maxilla, lateral view; $H$, endopod right maxilla, medial view; $I$, right 6 th limb, lateral view. 
terminal bristles (2 long, 1 small). Article 2 slightly curved; dorsal margin with 4 long bristles, 1 shorter marginal bristle proximal to small bristle with long spines, and 1 small bristle at midlength. Article 3 with 3 claws, 1 stout ringed ventral bristle, and 2 short bristles (1 ventral, 1 dorsal).

Maxilla (Figure $22 F-H$ ): Precoxa endite I with 6 bristles; coxa endite II with 6 bristles; coxa endite III with 1 proximal and 5 distal bristles (Figure 22F). Dorsal edges of precoxa and proximal part of coxa with marginal fringe of long hairs. Coxa without hirsute dorsal bristle (possibly broken off). Basis with 2 terminal bristles. Exopod well developed, hirsute, with 3 bristles (1 subterminal, 2 terminal) (Figure 22G). Endopod: article 1 with medial spines, triangular terminal ventral tooth, 2 alpha-bristles with long marginal hairs, and 2 beta-bristles (lateral inner bristle with short indistinct spines; medial outer bristle pectinate); article 2 with 4 a-bristles, 3 pectinate $b$-bristles, 3 pectinate c-bristles, and 3 pectinate $\mathrm{d}$-bristles.

Fifth limb (Figure 23A,B): Epipod fragmented, with bristles on remaining part. Coxa: endite I with 5 bristles; endite II with 5 bristles; endite III with 6 bristles. Basis: endite I with 1 medial proximal bristle, small medial triangular peg, and 3 stout terminal pectinate teeth (Figure 23A). Endite II: lateral side with proximal row composed of small sclerotized tooth and 4 bristles; spinous c-bristle present on medial side; d-bristle not observed; distal end with 4 stout pectinate a-bristles and 6 pectinate $b^{\prime}+b^{\prime \prime}$ bristles. Endopod: article 1 with 3 pectinate bristles; article 2 hirsute, with 3 bristles. Exopod hirsute, with 2 spinous terminal bristles.

Sixth limb (Figure 22I): With 1 short exopodial bristle. Endite I with 1 long terminal bristle; endite II with 1 short medial bristle and 1 terminal bristle; endite III with 1 short and 2 long bristles; endite IV with 1 short and 2 long bristles. End article with 6 bristles (2 posterior bristles longer than others and plumose). Both limbs with areas of black pigment.

Seventh limb (Figure 23C): Elongate, bare.

Furca (Figure 23D): Each lamella with 7 claws; claw 2 fused to lamella; claw 5 slightly wider than claw 4. Right lamella anterior to left by width of base of claw 1 .

Bellonci Organ: Short.

Eyes: Lateral eye well developed, with about 8 visible divided ommatidia but others hidden in black pigment (Figures 22A,D, $23 F)$. Medial eye about same size as lateral eye, amber colored.

Upper lip (Figure 23G,H): Unpaired anterior part with ventral edge bearing many small glandular processes; anterior half of anterior part of ventral edge with 5 or 6 stout glandular processes; posterior half of ventral edge does not project past ventral margin of anterior half and bears 7 narrower glandular processes. Paired posterior part of lip with glandular processes on outer side as well as along terminal edge; posterior edge bare. Spinous lateral flap at posterior end of posterior part of lip; flap with several indistinct spinelike processes.

Anterior process: Rounded knob on anterior of body between Bellonci Organ and upper lip.

Posterior of body (Figure 23I): Posterodorsal margin with spines just dorsal to girdle.

Genitalia: None observed.

Y-sclerite (Figure 23I): Without ventral branch.

DESCRIPTION OF INSTAR IV (Figures 2426): Carapace oval in lateral view, with prominent rostrum, incisure, and caudal process (Figure 24A). Rostrum with small lateral lobe and rounded tip; tip of caudal process linear; narrow crescentlike process extends past valve edge at anteroventral curvature of valve. Dorsal edge of left valve extends past dorsal edge of right valve.

Ornamentation: Outer surface of valves with abundant small postules (Figure 24B).

Chromatophores: Brown, closely packed particles distributed on inner side of valve probably not chromatophores (Figure $24 A$ ).

Infold: Not examined.

Selvage: Narrow lamellar prolongation along ventral edge of valve. Distal edge of lamellar prolongation smooth.

Hingement: Similar to that of adult female.

Central adductor muscle attachments: Obscured. 


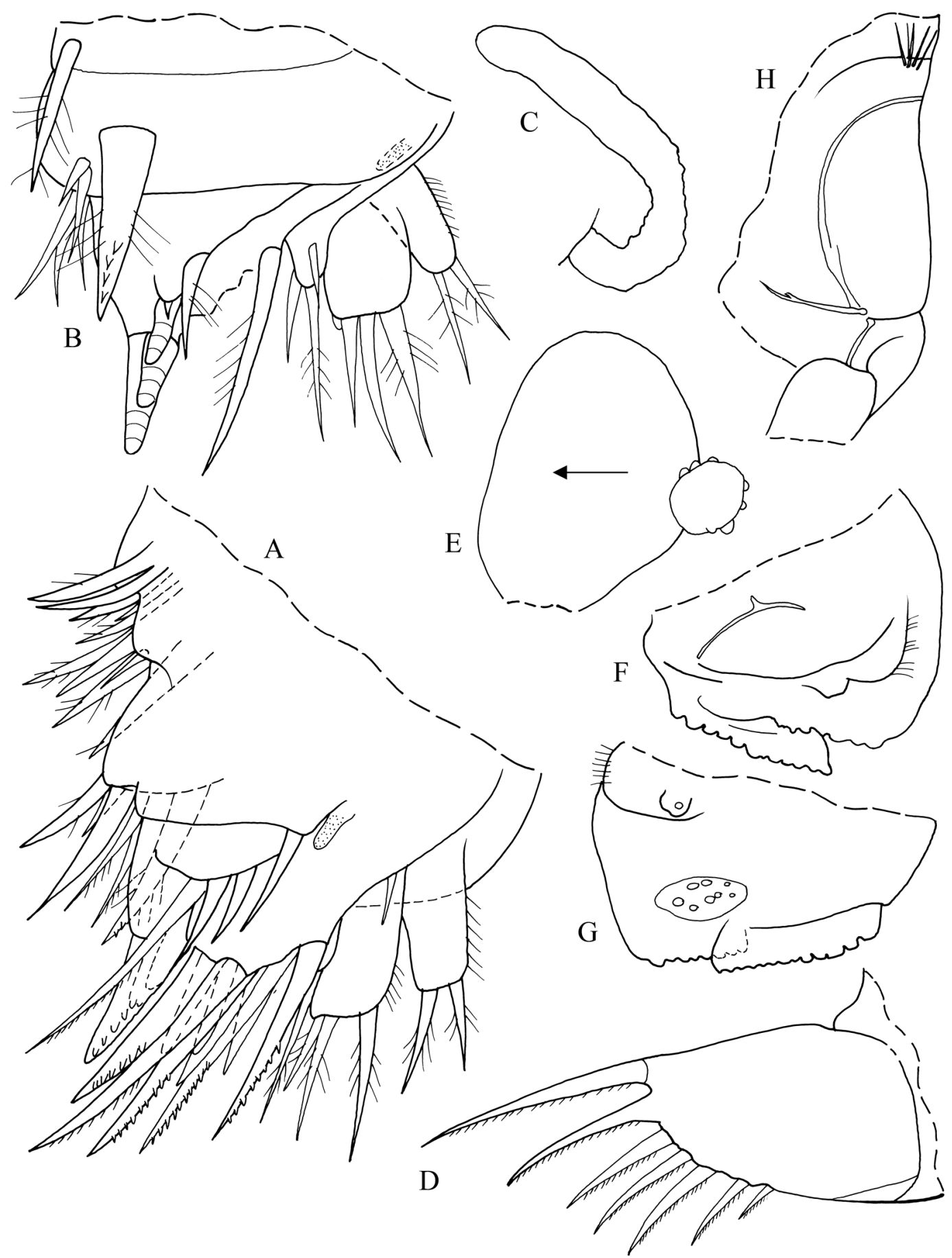

Figure 23. Pterocypridina colesi, paratype, врвм-S 14728, instar III: $A$, left 5th limb, lateral view (not all bristles shown); $B$, right 5th limb, medial view (not all bristles shown); $C, 7$ th limb; $D$, left lamella of furca, lateral view; $E$, protopod left 2nd antenna, left lateral eye, lateral view; $F, G$, right and left lateral views of upper lip (oval containing circles in $G$ appears to be displaced); $H$, posterior of body from left side. 

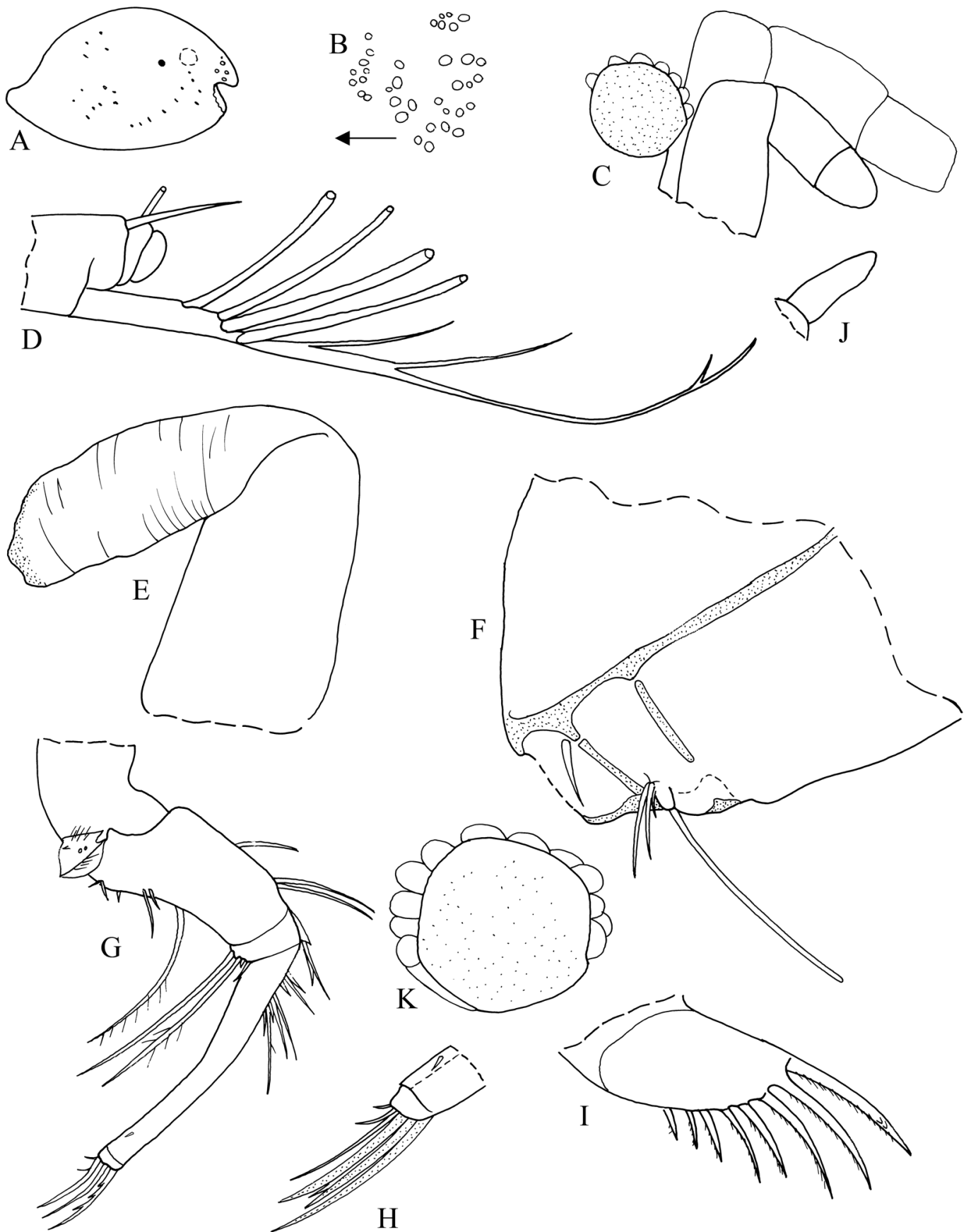

Figure 24. Pterocypridina colesi, paratype, врвм-S 14521, instar IV: $A$, complete specimen from right side, length 1.17 $\mathrm{mm} ; B$, muscle attachments on left valve (drawn from complete specimen; although in proper place, large number of attachments makes identification questionable); $C$, anterodorsal part of body from right side showing right lateral eye and articles 1-3 of left 1st antenna and article 1 to 2 or 3 of right 1 st antennae (right 1st antenna completely shown; it is missing distal part and tip is colored brown, indicating wound); $D$, part left 1st antenna, medial view (not all bristles shown); $E$, right 1 st antenna, medial view; $F$, part right 2 nd antenna, medial view; $G, H$, left mandible, medial view; $I$, right lamella of furca, lateral view; $\mathcal{F}$, Bellonci Organ; $K$, left lateral eye. 
Nodules: Absent.

Carapace size (length, height in $\mathrm{mm}$ ): врвм-S 14521, 1.17, 0.75 .

First antenna (Figure 24C-E): Articles 1 and 2 bare. Article 3 short, with 2 bristles (1 ventral, 1 dorsal). Article 4 with 2 short distal bristles (1 ventral, 1 dorsal). Sensory bristle of article 5 with 4 long filaments followed by 2 shorter and more slender filaments, and small filament near tip. Article 6 with short terminal medial bristle. Article 7: a-bristle short, broken; b-bristle broken, with 2 marginal filaments on stump; c-bristle much longer than b-bristle (tip of bristle missing on specimen examined; with 7 marginal filaments on remaining part). Article 8: $\mathrm{d}$ - and e-bristles filamentlike, about $2 / 3$ length of bristle of 5th article; f-bristle about same length as c-bristle (tip of bristle missing on specimen examined, with 6 marginal filaments, some with spines on remaining part); g-bristle about same length as c-bristle (tip missing on specimen examined, with 6 filaments, some with marginal spines on remaining part). Right limb with only 3 articles and terminates in brown wound (Figure 24C,E).

Second antenna (Figure 24F): Protopod with short distal medial bristle. Protopodial pivot broad. Endopod with 2 fused articles: article 1 with 3 anterior bristles; article 2 short, with long terminal filament. Exopod: bristle of 2 nd article reaching tip of 9th article, ventral margin with slender spines and hairs; bristle of article 3 long, with slender spine in middle part and natatory hairs distally; bristles of articles 4-8 long with natatory hairs; 9th article with 2 long bristles with natatory hairs and 1 short, bare dorsal bristle. Article 3 with minute lateral spine near ventral margin. Articles 4-8 with slender lateral spine near ventral margin. Article 8 with indistinct minute lateral spines along distal edge. Article 9 with small lateral spine near dorsal edge.

Mandible (Figure 24G,H): Coxa endite spinous; tip with 2 stout spines without peg between them; 2 small ringed bristles on endite near base (Figure 24G). Basis: ventral margin with 2 small medial a-bristles, 1 small lateral b-bristle, 2 small c-bristles, and 1 long stout spinous d-bristle; dorsal margin with 3 long bristles ( 1 near midlength, 2 terminal). Exopod slightly shorter than length of dorsal margin of endopod 1, with spinous tip and 2 subterminal ventral bristles. Endopod: article 1 with 4 ventral terminal bristles ( 2 long, 1 small, 1 minute). Article 2 slightly curved, with 1 minute subterminal medial bristle close to ventral margin; dorsal margin with 4 long bristles with short marginal spines, 2 shorter bristles (1 proximal, 1 distal), and 2 very short cleaning bristles (proximal of latter bristles with stout marginal spines). Article 3 with 3 stout claws, 3 bristles near ventral margin, and 1 indistinct lateral bristle.

Maxilla (Figure 25A,B): Precoxa endite I with $6+$ bristles; coxa endite II with 7 bristles; coxa endite III with 1 proximal and 7 distal bristles. Dorsal edge of precoxa with filmlike epipod with marginal fringe of long hairs. Coxa with hirsute dorsal bristle. Basis with 1 or 2 terminal bristles. Exopod well developed, hirsute, with 3 bristles (1 subterminal, 2 terminal). Endopod: article 1 with medial spines, triangular terminal ventral tooth, 2 alphabristles and 2 beta-bristles; article 2 with 4 abristles (inner bristle pectinate), 3 b-bristles, $3 \mathrm{c}$-bristles, and $3 \mathrm{~d}$-bristles.

Fifth limb (Figures 25D,E, 26A): Epipod with setose bristles. Coxa: endite I with 7 bristles; endite II with 6 bristles; endite III with 7 bristles. Basis: endite I with 1 medial proximal bristle, small medial triangular peg, and 4 stout terminal pectinate teeth (Figure $25 E)$. Endite II: lateral side with proximal row composed of small sclerotized tooth and 4 bristles; small d-bristle present near outer edge of distal edge of endite (Figure 26A); medial side with long spinous proximal cbristle (Figure $25 C$ ); distal end with 8 stout pectinate $a-, b^{\prime}-$, and $b^{\prime \prime}$-bristles. Endopod: article 1 with 3 bristles; article 2 hirsute, with 4 spinous terminal bristles. Exopod hirsute, with 2 spinous terminal bristles.

Sixth limb (Figure 26B): With 2 short exopodial bristles. Endite I with 1 short medial and 2 long terminal bristles; endite II with 2 short medial bristles and 1 long terminal bristle; endite III with 1 short medial and 4 terminal bristles (1 short, 3 long); endite IV with 4 terminal bristles (2 short, 2 long). End article with 11 bristles (2 posterior 


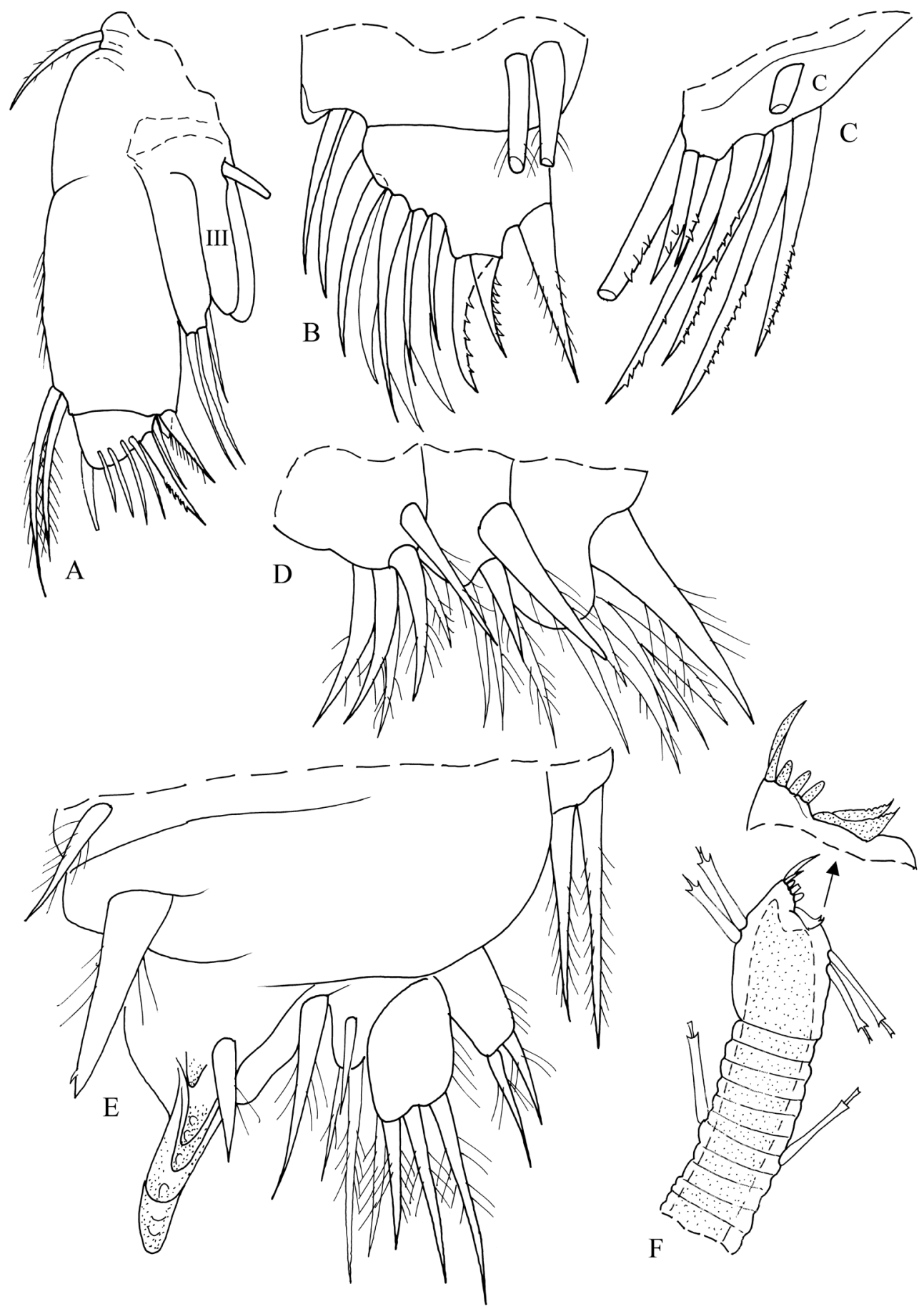

Figure 25. Pterocypridina colesi, paratype, врвм-S 14521, instar IV: $A$, part left maxilla, lateral view; $B$, distal part right maxilla, medial view; $C$, basis endite II right 5 th limb, medial view; $D$, coxa endites I-III (left to right) right 5 th limb, medial view; $E$, distal part right 5 th limb, medial view (not all bristles shown); $F$, 7 th limb. 

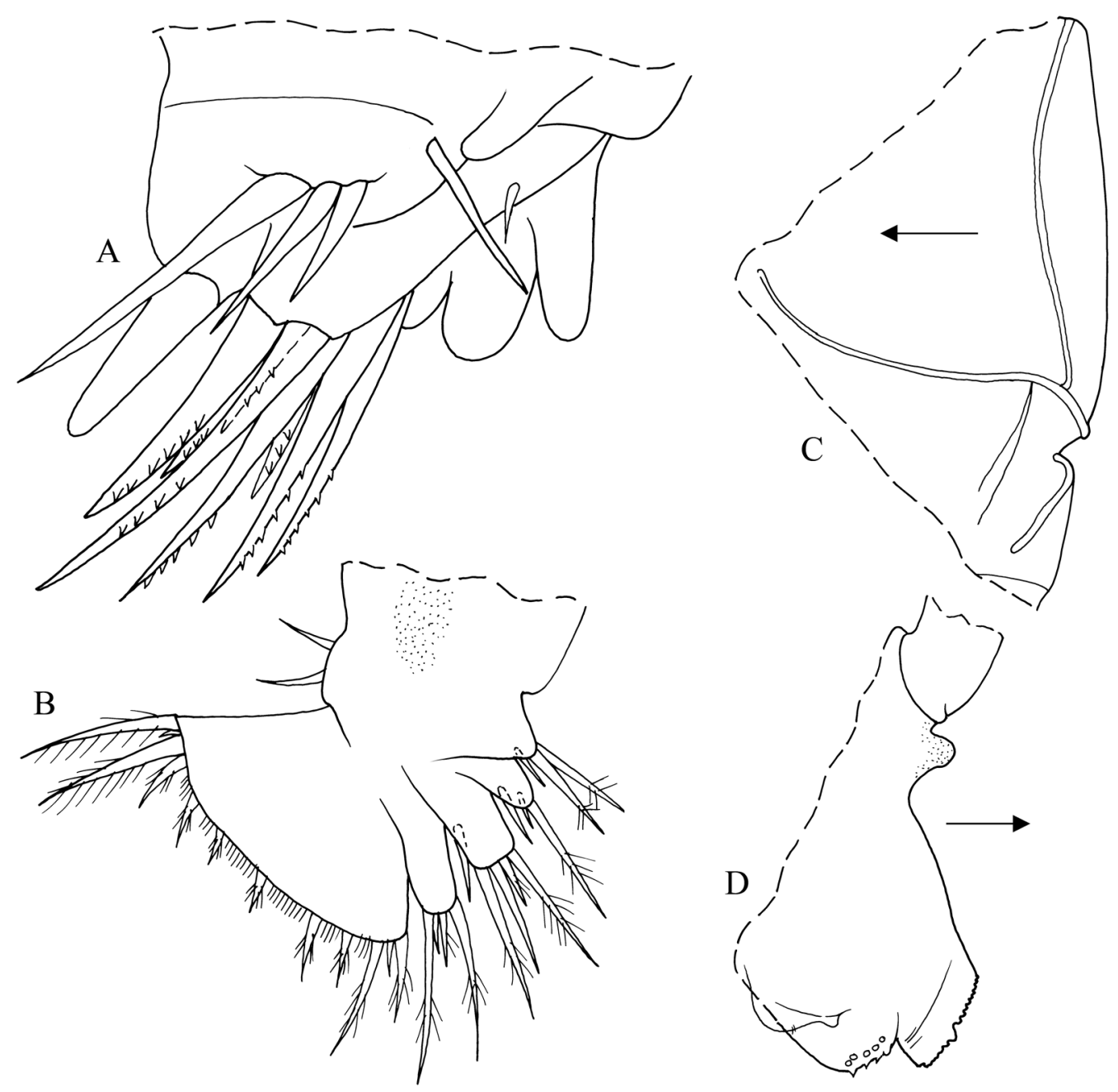

Figure 26. Pterocypridina colesi, paratype, врвм-S 14521, instar IV: $A$, distal part left 5 th limb, lateral view (not all bristles shown); $B$, right 6th limb, lateral view; $C$, posterior of body from left side; $D$, Anterior of body from right side showing upper lip, anterior process, and article 1 of right 1 st antenna.

bristles longer than others and plumose). Both limbs with brown areas.

Seventh limb (Figure 25F): With 2 articles. Proximal article annulate and with 2 tapered bristles ( 1 on each side, each with 1 bell and flaring terminal process). Terminal article with 4 bristles (2 on each side, each with 1 bell and flaring terminal process). Comb with 3-4 short teeth with square tips on each side of 3 pointed longer teeth (short tooth on each side of single long tooth). Side opposite comb with small ridge with minute teeth along distal edge.

Furca (Figure 24I): Each lamella with 8 claws; claw 2 fused to lamella; claw 6 very slightly broader than claw 5. All claws with slender teeth along posterior edge. Claw 1 with fairly stout distal medial tooth. Right lamella anterior to left by width of base of claw 1.

Bellonci Organ (Figure 247): Short, pearshaped. 
Eyes: Lateral eye well developed, with about 12 visible divided ommatidia but others hidden in black pigment (Figure 24A,C,K). Medial eye about same size as lateral eye, amber colored.

Upper lip (Figure 26D): Unpaired anterior part with ventral edge bearing many small glandular processes; posterior half of ventral edge projects slightly farther than anterior half and bears many minute processes. Paired posterior part of lip with glandular processes on outer side as well as along terminal edge.

Anterior process (Figure 26D): Rounded knob on anterior of body between Bellonci Organ and upper lip.

Posterior of body (Figure 26C): Evenly rounded, bare.

Genitalia: None observed.

Y-sclerite: Without ventral branch.

Posterior of body (Figure 26C): Evenly rounded, bare.

Injury (Figure 24C,E): The right 1st antenna of the illustrated specimen is without the distal end past the 3rd article, which is brown at the tip. Apparently the specimen was able to survive with that injury.

DESCRIPTION OF INSTAR V MALE (Figures 27, 28): (Specimen about to molt; adult visible inside specimen.) Carapace oval in lateral view, with prominent rostrum, incisure, and caudal process (Figure 27A,B). Rostrum with small lateral lobe and rounded tip; tip of caudal process linear; narrow crescentlike process extends past valve edge at anteroventral curvature of valve. Dorsal edge of left valve extends past dorsal edge of right valve.

Ornamentation: Surface of valves without small, shallow, rounded fossae. Curved row of minute serrations extends from inner end of incisure to anterior edge of valve ventral to incisure.

Chromatophores: None observed on specimen examined.

Infold: In general, similar to that of adult male and female (Figure 27B).

Selvage: Similar to that of adult female.

Hingement: Similar to that of adult female.

Central adductor muscle attachments: Not clear but consisting of about 8 attachments.

Nodules: None observed.
Carapace size (length, height in $\mathrm{mm}$ ): врвм-S 14540, 1.43, 0.82.

First antenna (Figure 27C): Articles 1 and 2 bare. Article 3 short, with 2 bristles (1 ventral, 1 dorsal). Article 4 with short distal ventral bristle. Sensory bristles of article 5 with 6 long filaments followed by 3 shorter and more slender filaments with few marginal spines, and 1 minute subterminal bristle. Article 6 with short terminal medial bristle. Article 7: a-bristle slightly longer than bristle of article 6; b-bristle long, with 3 long filaments, some with a few minute spines; minute spines on bristle following last filament; distal part of bristle broken. Article 8: c-bristle much longer than b-bristle, with at least 8 short filaments with marginal spines (tip of bristle obscured); d- and e-bristles filamentlike; $\mathrm{f}$ and g-bristles with numerous long, thin proximal hairs followed by 9 short filaments (some with spines) and bifurcate tip (Figure 27C).

Second antenna (Figure 27E): Protopod without lateral spines near dorsal margin, and with short distal medial bristle; protopodial pivot broad. Endopod: article 1 with 4 anterior bristles (3 short, 1 long); small article 2 fused to article 1, with very long terminal filament. Exopod: bristle of 2 nd article reaching tip of 9th article, with long hairs on both ventral and dorsal margins; bristles of articles 3-8 long, with natatory hairs; 9th article with 4 bristles with natatory hairs, dorsal bristle short. Articles 5-8 with stout lateral spine near ventral margin. Article 9 with lateral spine near dorsal edge.

Mandible: Coxa endite spinous; tip with 2 stout spines without peg between them; 2 minute bristles on endite near base. Basis: ventral margin with 2 small medial a-bristles, 1 minute lateral b-bristle, 2 small c-bristles, and 1 long stout spinous d-bristle; dorsal margin with 3 bristles (1 near midlength, 2 terminal). Exopod shorter than dorsal margin of endopod 1, with spinous tip and 2 subterminal ventral bristles. Endopod: article 1 with 4 ventral terminal bristles ( 2 long, 1 small, 1 minute). Article 2 curved; dorsal margin with 4 long bristles, some with short marginal spines, 2 shorter bristles (1 proximal, 1 distal), and 2 very short cleaning bristles (proximal cleaning bristle with long spines). Article 3 


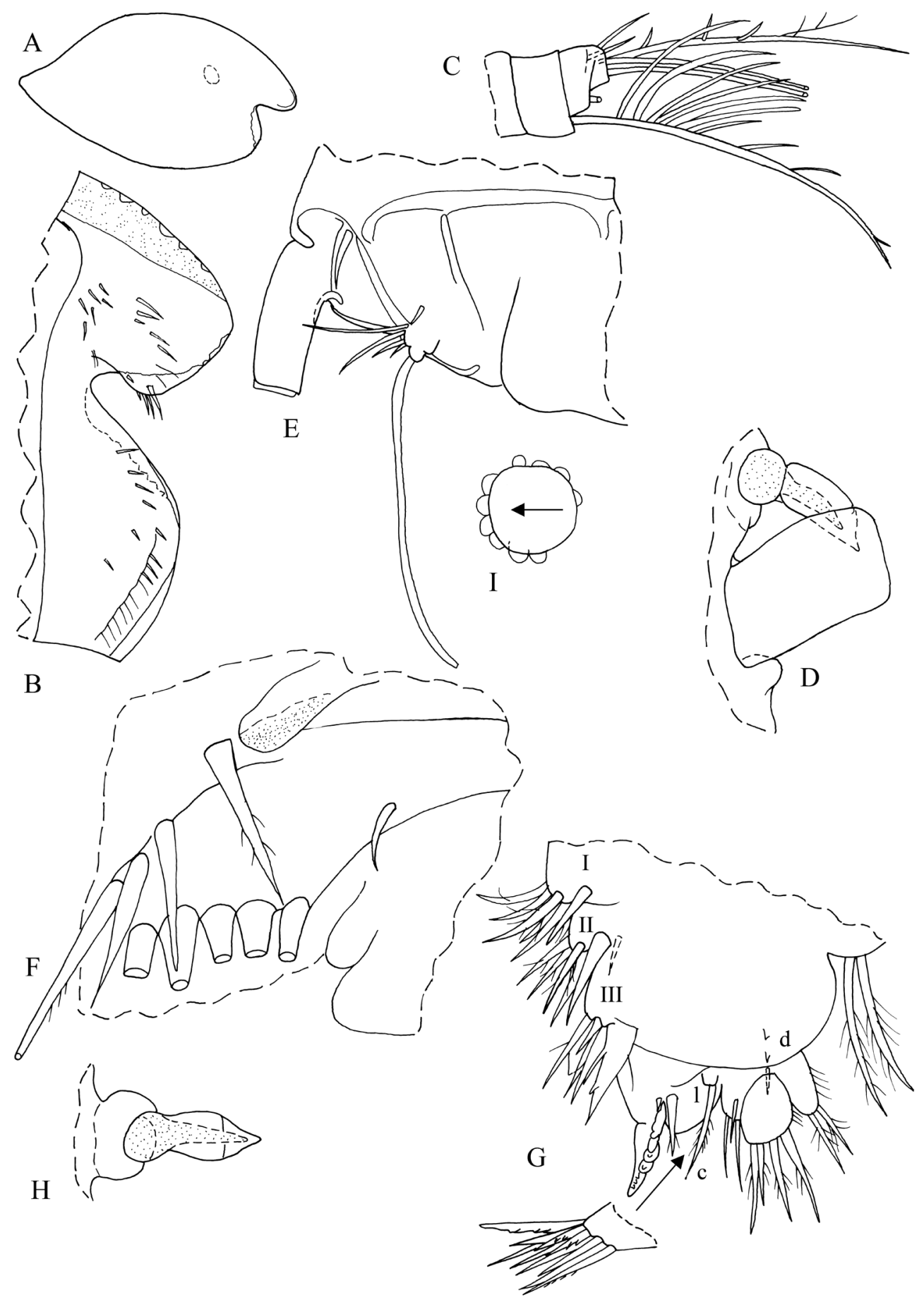

Figure 27. Pterocypridina colesi, paratype, врвм-S 14540, instar V: A, complete specimen from right side, length 1.43 $\mathrm{mm} ; B$, anterior left valve, inside view; $C$, distal end right 1st antenna (drawn on body), lateral view; $D$, anterior of body showing anterior process, medial eye, Bellonci Organ, and article 1 of right 1st antenna; $E$, part right 2nd antenna, medial view; $F$, part left 5 th limb, lateral view (not all bristles shown); $G$, part right 5 th limb, medial view; $H$, medial eye and Bellonci Organ; $I$, left lateral eye drawn on body. 
with 3 stout claws, 1 long ringed clawlike bristle near ventral edge, 2 short bristles near ventral margin, and 1 small lateral bristle near dorsal margin.

Maxilla: Precoxa endite I with 10 bristles; coxa endites II and III with numerous obscured bristles. Dorsal edge of precoxa with filmlike epipod with marginal fringe of long hairs. Coxa with hirsute dorsal bristle. Basis with 1 or 2 terminal bristles. Exopod well developed, hirsute, with 3 bristles (1 subterminal, 2 terminal). Endopod: article 1 with medial spines, triangular terminal ventral tooth, 2 spinous alpha-bristles, and 2 short beta-bristles; article 2 with 4 a-bristles (inner bristle pectinate), 3 b-bristles, 3 c-bristles, and $3 \mathrm{~d}$-bristles.

Fifth limb (Figure 27F,G): Epipod with 45 setose bristles. Coxa: endite I with 5 bristles; endite II with 5 bristles; endite III with 6 bristles. Basis: endite I with 1 medial proximal bristle, small medial triangular peg, and 5 stout terminal pectinate teeth (Figure 27G). Endite II with about 9 terminal bristles, medial proximal c-bristle, and proximal d-bristle (additional bristle obscure). Endopod: article 1 with 3 spinous bristles ( 1 subterminal, 2 terminal); article 2 hirsute, with 4 terminal bristles. Exopod hirsute, with 2 spinous terminal bristles.

Sixth limb: With 3 short exopodial bristles. Endite I with 2 short medial and 2 long terminal bristles; endite II with 1 or 2 short medial bristles and 2 terminal bristles (1 long, 1 short); endite III with 1 short medial bristle and 4 terminal bristles (1 short, 3 long); endite IV with 1 short proximal bristle and 4 terminal bristles ( 3 short, 2 long). End article with 17 bristles ( 4 very short; 2 posterior bristles longer than others and plumose). Both limbs with central area with amber color; without areas of black pigment.

Seventh limb (Figure 28B): With 2 articles. Proximal article with 92 annuli and 7 or 8 distal tapered bristles (3 or 4 on each side), each with 1 to 5 bells. Terminal article with 4 tapered bristles on comb side, each with 1 to 4 bells, and 4 bristles on opposite side, each with 1 to 4 bells. Comb with 4 short teeth with square tips on each side of 3 longer teeth with pointed tips, about 11 teeth total (not all shown in illustrated limb). Side opposite comb with small ridge with minute teeth along edge.

Furca (Figure 28C): Lamella with 9 claws; claw 2 fused to lamella; claw 5 slightly wider than claw 4. All claws with slender teeth along posterior edge. Claw 1 with fairly stout distal medial tooth. Margin following last claw with minute spines. Right lamella anterior to left by width of base of claw 1 .

Bellonci Organ (Figure 27D,H): Short with tapered tip.

Eyes: Lateral eye well developed, with about 30 visible divided ommatidia (Figure $27 A, I)$. Medial eye about same size as lateral eye, amber colored (Figure 27D,H).

Upper lip: Similar to that of instar IV.

Posterior of body (Figure 28C): Posterodorsal margin evenly rounded, bare.

Genitalia (Figures 28C): Composed of 2 elongate processes with internal complex structures.

Y-sclerite (Figure 28C): Without ventral branch.

Gut content: Unrecognized particulate matter.

ADUlt SEXUAL Dimorphism: Male carapace smaller than that of female. Male 1st antenna with suckers on b- and c-bristles. Mandible (2 females and 1 male examined): ventral margin of 2 nd endopod article with 2 short cleaning bristles on female and 6 on male. Y-sclerite of male with small ventral branch absent on female. Lateral eyes about same size on males and females, and with about same number of ommatidia.

Discussion of ontogenY: Knowledge of the life cycle of a species permits identification of the stage under study. The species $P$. colesi has six instars, which are described here. Sex was not determined on instars I to IV. Listed below are some changes that occur in the morphology of the carapace and certain appendages on progressive instars. The changes selected are useful for the identification of each instar. The ontogenetic development of appendages is shown in Table 2.

Carapace: The carapace lengths $(\mathrm{mm})$ of instars are as follows: instar I, 0.66-0.68; instar II, 0.77; instar III, 0.99; instar IV, 1.17; instar $\mathrm{V}$ male, 1.43; adult female, 2.20-2.22; 


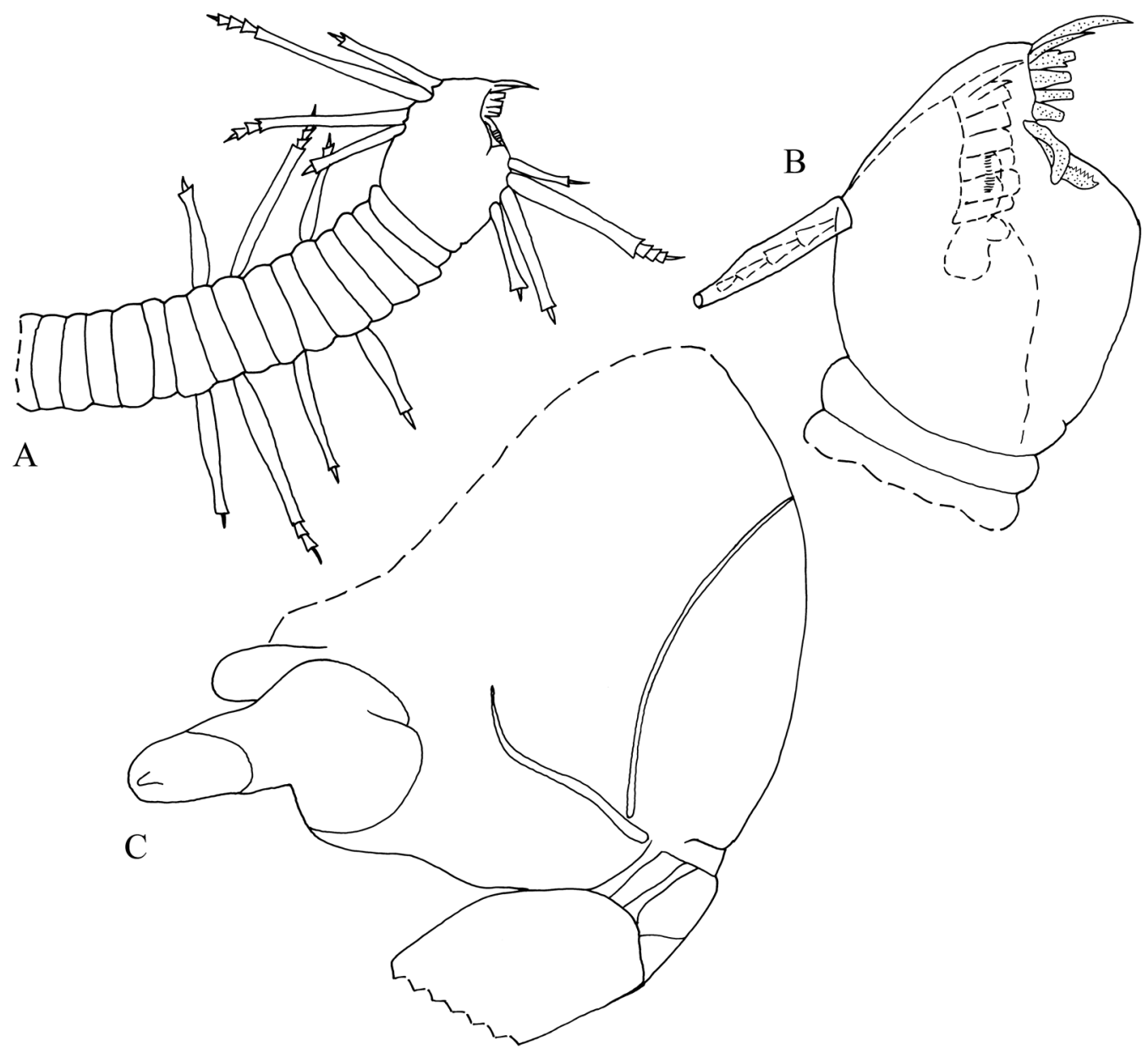

Figure 28. Pterocypridina colesi, paratype, врвм-S 14540, instar V: $A, B, 7$ th limb; $C$, posterior of body from left side showing left copulatory organ, proximal part of furca, and Y-sclerite without ventral branch.

and adult male, 1.69-1.79. The growth factors between instars are as follows: instars I to II, 1.15 ; instars II to III, 1.29 ; instars III to $\mathrm{IV}, 1.17$; instars IV to $\mathrm{V}$ male, 1.22 ; and instars $\mathrm{V}$ male to adult male, 1.18-1.25.

First antenna: Bristles on 4th article: Instar I without bristles; instar II with 1 minute dorsal bristle; instars III, IV, and adult female with 2 short bristles, 1 ventral, 1 dorsal; instar $\mathrm{V}$ male and adult male with 1 short distal ventral bristle. Number of marginal filaments on sensory bristle of 5 th article: instar I bare; instar II with 3 long proximal and 2 shorter, distal, marginal filaments; instar III with 4 long and 3 short; instar IV with 4 long and 2 short; instar $\mathrm{V}$ male with 6 long and 3 short; adult female with 8 long and 3 short; adult male with 9 long and 3 short. The b-bristle of the 7 th article and the c-bristle of the 8th article of the adult male bear 1 or more suckers. Suckers are absent on the instar V male and adult male, as well as earlier instars (assumed to be absent on instar I, which had fragmented c-bristles).

Second antenna: Endopod with 2 articles (fused on some instars): article 1 without bristles on instar I, 1 bristle on instar II, 2 bristles on Instar III, 3 bristles on instar IV, 4 bristles 
TABLE 2

Length of Carapace (mm) and Number of Bristles on Appendages of Different Stages of Pterocypridina colesi

\begin{tabular}{|c|c|c|c|c|c|c|c|c|}
\hline Character & $\begin{array}{l}\text { Stage: } \\
\text { Sex: }\end{array}$ & $\begin{array}{l}\text { I } \\
?\end{array}$ & $\begin{array}{l}\text { II } \\
?\end{array}$ & $\begin{array}{c}\text { III } \\
?\end{array}$ & $\begin{array}{c}\text { IV } \\
?\end{array}$ & $\begin{array}{l}\mathrm{V} \\
\mathrm{M}\end{array}$ & $\begin{array}{c}\mathrm{Ad} \\
\mathrm{F}\end{array}$ & $\begin{array}{l}\mathrm{Ad} \\
\mathrm{M}\end{array}$ \\
\hline Length & & 67 & 0.77 & 0.99 & 1.17 & 1.43 & 2.19 & 1.74 \\
\hline \multicolumn{9}{|l|}{ No. bristles } \\
\hline First antenna & & 12 & 12 & 12 & 13 & 13 & 13 & 12 \\
\hline \multicolumn{9}{|c|}{ Second antenna } \\
\hline Protopod & & 1 & 1 & 1 & 1 & 1 & 1 & 1 \\
\hline Endopod & & 2 & 2 & 3 & 4 & 5 & 5 & 5 \\
\hline Exopod & & 10 & 11 & 10 & 10 & 10 & 11 & 10 \\
\hline \multicolumn{9}{|l|}{ Mandible } \\
\hline Basis & & 6 & 9 & 10 & 10 & 9 & 9 & 9 \\
\hline Exopod & & 2 & 2 & 2 & 2 & 2 & 2 & 2 \\
\hline Endopod & & 13 & 15 & 16 & 20 & 19 & 19 & 19 \\
\hline \multicolumn{9}{|l|}{ Maxilla $^{a}$} \\
\hline Exopod & & 3 & 3 & 3 & 3 & 3 & 3 & 3 \\
\hline Endopod & & 7 & 11 & 17 & 20 & 18 & 18 & 17 \\
\hline Fifth $\operatorname{limb}^{a}$ & & 21 & 39 & 41 & 44 & 39 & 48 & 46 \\
\hline Sixth limb & & 0 & 1 & 16 & 27 & 37 & 42 & 41 \\
\hline Seventh limb & & 0 & 0 & 0 & 6 & 16 & 21 & 25 \\
\hline Furca & & 5 & 5 & 7 & 8 & 9 & 10 & 10 \\
\hline Genitalia $^{b}$ & & - & - & - & - & - & + & + \\
\hline
\end{tabular}

${ }^{a}$ Endite bristles of maxilla and epipodial bristles of 5 th limb not included.

$b+$, Present.

on instar $\mathrm{V}$ male and adult female and male. The 9th article of the exopod with 2 bristles on instar I, 3 bristles on instars II, III, and $\mathrm{IV}$, and 4 bristles on instars $\mathrm{V}$ male, adult female, and adult male.

Sixth limb: Limb of instar I with spines but no bristles. Limb of instar II with 1 bristle on single endite, none on end article. Older instars with many bristles.

Seventh limb: The limb was not observed on instar I and is probably absent. On instar II the limb is fingerlike, bare, and unsegmented. It is longer but remains bare on instar III. On later instars the limb bears bristles and also a terminal comb bearing teeth. The bristles are tapered on instars III to $\mathrm{V}$, and cylindrical on adults. The limb bears 6 bristles on instar IV, 15 or 16 on instar V male, 21 bristles on adult female, and 24 or 25 bristles on adult male. Each bristle bears 1 bell on instar IV, 1 to 4 or 5 bells on instar $\mathrm{V}$ male, and 1-7 bells on the adult female and male.
Furca: Each lamella of the furca of instars I and II bears 5 claws, but instar I has claws 2 to 5 fused to each lamella, whereas instar II, as well as later instars, has only claw 2 fused. Each lamella of the furca of instar III bears 7 claws; instar IV bears 8 claws; instar $\mathrm{V}$ male bears 9 claws, and the adult female and male each bear 10 claws.

comparisons: The new species, P. colesi, differs from P. nex Kornicker \& Thomassin, 1998, from Madagascar in the following: (1) the endopod of the 2 nd antenna of $P$. nex is composed of one article compared with two on $P$. colesi; (2) the 5th claw of the furca of $P$. nex is much broader than the 4th claw, and only slightly broader on P. colesi; and (3) the female of $P$. nex is $2.64 \mathrm{~mm}$ long compared with $2.12-2.25 \mathrm{~mm}$ for $P$. colesi. The carapace of $P$. colesi differs from those of $P$. alata Poulsen, 1962; P. appendix Kornicker in Kornicker and Poore, 1996; P. dedeckkeri Kornicker, 1983; P. excreta Poulsen, 1962; and P. tressleri Kornicker in Kornicker and Poore, 1996, in 
not having a posterodorsal process. The protopod of the second antenna of the female $P$. colesi differs from that of $P$. birostrata Poulsen, 1962, in having a distal medial bristle. The furca of $P$. pax Kornicker in Kornicker and Poore, 1996, differs from that of $P$. colesi in having claw 4 broader than claw 3 and different shape of valves. The furca of P. sex Kornicker, 1983, differs from that of $P$. colesi in having claw 4 fused to lamella.

Superfamily Sarsielloidea Brady \& Norman, 1896

Family Pseudophilomedidae Kornicker, 1967

Subfamily Pseudophilomedinae Kornicker, 1967

composition: The subfamily includes four genera, of which only Harbansus box Kornicker et al., 2007, is in this collection.

Genus Harbansus Kornicker, 1978

TYPE SPECIES: Harbansus bradmyersi Kornicker, 1978.

COMPOSITION AND Distribution: The genus contains 20 species plus two left in open nomenclature and is cosmopolitan at depths of subtidal to $1,015 \mathrm{~m}$ (Kornicker et al. 2007). Harbansus barnardi Kornicker, 1978, was previously described from Kāne'ohe Bay, O'ahu.

Harbansus box Kornicker et al., 2007

Harbansus box Kornicker et al., 2007:48, figs. 23-29.

HOLOTYPE: врвм-S 12868, ovigerous female in alcohol.
TyPe Locality: French Frigate Shoals. material examined: Kaua'i, Sta. Har4, врвм-S 12868, 1 adult female in alcohol. Distribution: French Frigate Shoals; Kaua'i.

SUPPLEMENTARY DESCRIPTION OF adult FEMAle: Carapace size (length, height in mm), UsNM 1121719, 1.14, 0.56 .

Eggs: USNM 1121719 with 4 eggs in marsupium.

\section{Superfamily Cylindroleberidoidea Müller, 1906 \\ Family Cylindroleberididae Müller, 1906 \\ Subfamily Cylindroleberidinae Müller, 1906}

composition: This subfamily includes two tribes, Cylindroleberidini Müller, 1906, and Bruuniellini Kornicker \& HarrisonNelson, 2005, of which only the former is represented in this collection.

Tribe Cylindroleberidini Müller, 1906

composition: This tribe contains 17 genera, of which two are represented in this collection.

\section{Genus Parasterope Kornicker, 1975}

TYPE sPeCiEs: Asterope muelleri Skogsberg, 1920:483; subsequent designation by Kornicker (1975:401).

COMPOSITION AND DISTRIBUTION: This genus contains numerous species. Widespread between latitudes of about $55^{\circ}$ and $65^{\circ} \mathrm{S}$. Depth range intertidal to $4,303 \mathrm{~m}$ (Kornicker and Caraion 1974:7).

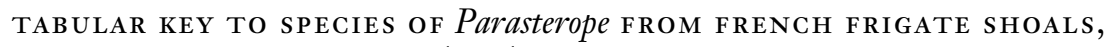
KAUA'I, O'AHU, AND MAUI

(A, number of bristles on 9th article of exopod of 2 nd antenna; B, presence $(+)$ or absence $(-)$ of basal spines on exopod of 2 nd antenna; $C$, spines present $(+)$ or absent $(-)$ on protopod of 2nd antenna; D, presence $(+)$ or absence $(-)$ of midbristle on dorsal margin of basis of mandible; E, presence $(+)$ or absence $(-)$ of nontriaenid bristle proximal to U-shaped process on ventral margin of basis of mandible. P. theta is an adult male; the remaining species are adult females.) 
Species

P. gamma Kornicker et al., 2007

P. iota Kornicker et al., 2007

P. moseri Kornicker, Harrison-Nelson \& Coles, n. name

P. omega Kornicker et al., 2007

P. sigma Kornicker et al., 2007

P. theta Kornicker et al., 2007

Parasterope gamma Kornicker et al., 2007 Figures 29, 30

HоLOTYPE: врвм-S 12861, ovigerous female on slide and in alcohol.

TyPe locality: Kapua Channel, Waikīkī, O’ahu, Hawaiian Islands.

material examined: Kaua'i: Sta. Har3, Port Allen main docks, врвм-S 14546, female with large unextruded eggs (furca missing from specimen), on slide and in alcohol; Sta. K3, Port Allen, врвм-S 14598, 2 specimens. Maui: Sta. H1, Kahului Harbor Pier 1, врвм-S 14602, 1 specimen; Sta. H2, Kahului Harbor Pier 2, UsNM 1121721, 1 specimen, врвм-S 14547, 4 specimens; Sta. H3, Mā‘alaea reef, usNм 1121724, 1 specimen, врвм-S 14561, 24 specimens; Sta. H4, Mā‘alaea Harbor, вРвм-S 14599, ovigerous female in alcohol; Sta. M3, Kahului Harbor Pier 1, врвм-S 14600, 1 specimen.

distribution: Hawaiian Islands: Kaua'i, O'ahu, and Maui.

SUPPLEMENTARY DESCRIPTION OF adult female (Figures 29, 30): Carapace elliptical in lateral view (Figure 29A).

Central adductor muscle attachments (Figure 29B): Each valve with about 11 oval attachments.

Carapace size (length, height in $\mathrm{mm}$ ): врвм-S 14546, 0.90, 0.58 .

First antenna (Figure 29C): Left limb (врвм-S 14546): 1st article bare. 2nd article with few proximal dorsal spines, long spinous dorsal bristle, and short distal lateral bristle. 3rd and 4th articles partly separated by oblique suture better developed on medial side. 3rd article: short ventral margin with small bristle; long dorsal margin with 6 long bristles ( 2 with bases lateral, 4 with bases along dorsal edges); 4th bristle along edge with short spines, other 3 bristles along edge

\begin{tabular}{ccccc}
\multicolumn{7}{c}{ Morphological Characters } \\
A & B & C & D & E \\
3 & - & - & - & - \\
4 & + & - & - & - \\
4 & + & + & - & + \\
4 & + & + & + & - \\
4 & + & + & - & - \\
4 & - & - & - & +
\end{tabular}

with long proximal spines. 4th and 5th articles separated by concave suture. 4th article with 3 terminal bristles (2 ventral, 1 dorsal) and few dorsal spines. Sensory bristle of 5th article with 6 long filaments with all bases close to tip. 6th article with spinous medial bristle reaching past tip of a-bristle. 7th article: a-bristle clawlike, bare; b-bristle with 3 long marginal filaments; c-bristle long with 4 marginal filaments; d-bristle absent; ebristle longer than a-bristle, bare with blunt tip; f-bristle bent dorsally, with 4 marginal filaments; g-bristle long with 4 marginal filaments. Right limb of врвм-S 14546 aberrant: 2nd article with 2 dorsal bristles and no lateral bristle; 3 rd article with only 3 dorsal bristles and no ventral bristle; 4th article without ventral bristles; 5th article without sensory bristle; 6th article without medial bristle; 7th article with clawlike a-bristle but no bor c-bristles; 8th article with normal e-bristle and aberrant $\mathrm{f}$ - and $\mathrm{g}$-bristles ( $\mathrm{g}$-bristle could be interpreted to be b-bristle).

Second antenna (Figure 29D,E): Protopod with short distal medial bristle, otherwise bare (Figure 29D). Endopod without visible sutures and with long terminal filament (Figure 29E). Exopod: bristle of 2nd article reaching just past 9th article, with short marginal spines; bristles of articles 3 to 8 with long bristles with natatory hairs; 9th article with 3 bristles (dorsal bristle short bare, middle bristle with indistinct short spines, longer ventral bristle with natatory hairs). Exopod articles without basal spines. Article 9 with lateral spine with digitate tip.

Mandible (Figures 29F-H, 30A): Coxa endite (Figure 29G, $H$ ): small bristle at base of ventral branch; ventral branch with 3 rows of spines and pointed tip; dorsal branch with 4 pointed processes followed by 3 low nodes proximal to small main spine; tip of dorsal 


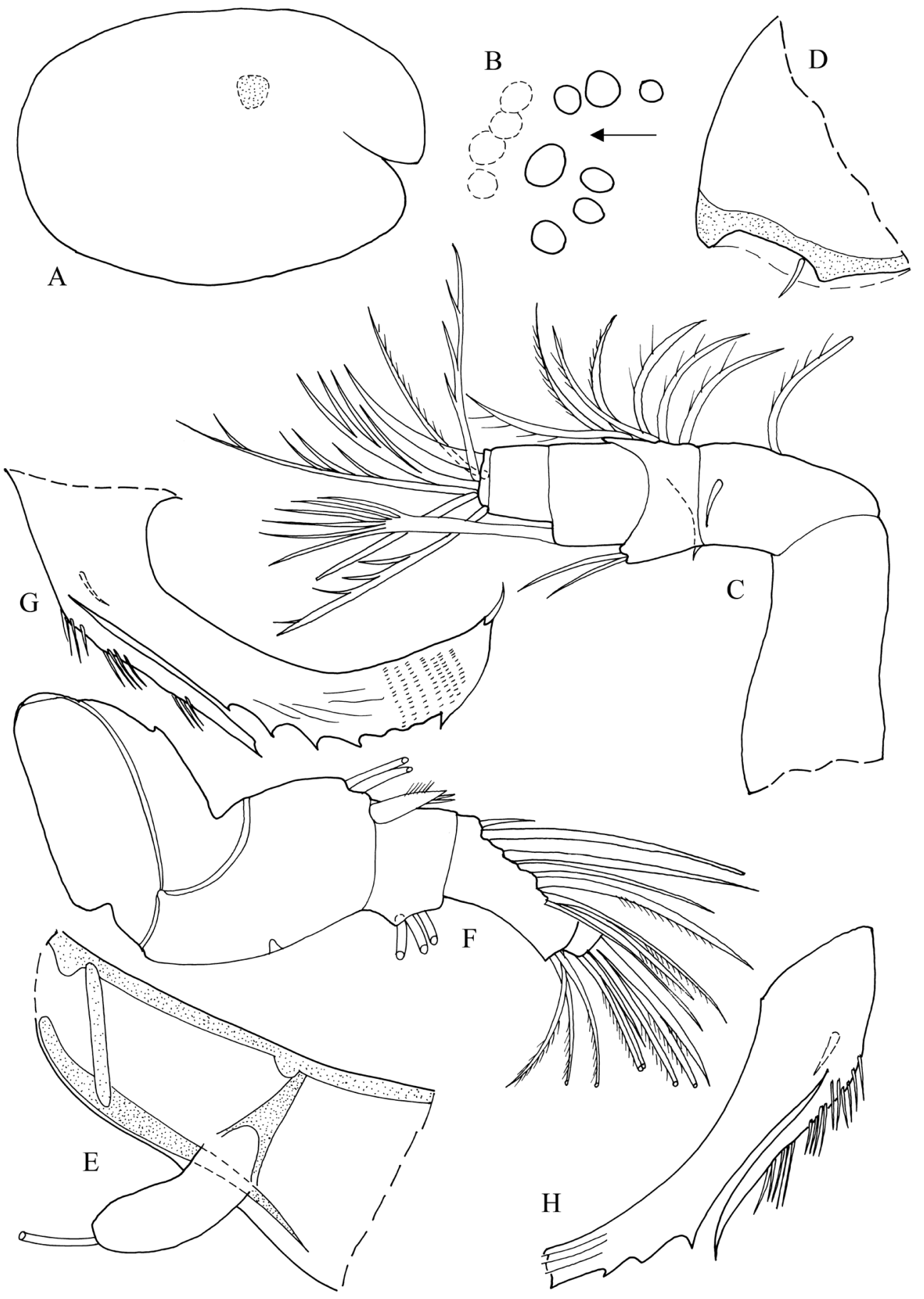

Figure 29. Parasterope gamma, врвм-S 14546, adult female: $A$, complete specimen, length $0.90 \mathrm{~mm}$; $B$, central adductor muscle attachments, left valve, outside view; $C$, left 1st antenna drawn on body, lateral view; $D$, distal part protopod right 2 nd antenna, medial view; $E$, part of protopod and endopod right 2 nd antenna, medial view; $F$, right mandible, lateral view (medial cleaning bristles not shown); $G$, coxa endite left mandible, lateral view; $H$, coxa endite right mandible, lateral view. 
branch pointed and with dorsal bristle with base slightly proximal to the pointed tip. Basis endite with 4 spinous end bristles, 2 or 3 triaenid bristles with about 3 pairs of marginal spines proximal to terminal pair, 1 dwarf bristle, and very small glandular peg (Figure $30 A$ ). Ventral margin of basis with U-shaped process, no bristles; dorsal margin with 2 long terminal bristles. Exopod almost as long as dorsal margin of 1st article of endopod, with dorsal hairs and 2 short subterminal bristles. Endopod: 1st article with 3 long spinous ventral bristles (shortest with short marginal spines, others with long spines near midlength). 2nd article: dorsal margin with short proximal bristle followed by long spinous $\mathrm{a}-$, b-, c-, and d-bristles (c-bristle slightly stouter than others); lateral side of dorsal margin with 1 long bristle between $b-$ and c-bristles, and 1 long bristle between c- and $\mathrm{d}$-bristles, or at base of d-bristle; medial side near dorsal margin with 4 cleaning bristles ( 1 between $b$ - and c-bristles and 3 forming row at proximal base of c-bristle), and 1 long bristle at distal base of d-bristle; ventral margin with 3 long bristles with short marginal spines (middle medial bristle shorter than others). 3rd endopod article with stout terminal claw with minute ventral spines and distal dorsal spines, 3 long terminal bristles with short marginal spines, 1 short medial spinous bristle near ventral margin, and 1 long spinous medial bristle just ventral to base of dorsal claw.

Maxilla (Figure 30B) (endopod twisted): Endite I with 4 bristles (3 long, 1 short). Epipod with pointed tip reaching past midlength of dorsal margin of basis. Basis with short proximal lateral bristle near midheight, distal short dorsal bristle, proximal backwardpointing short ventral bristle, short distal ventral bristle, and long spinous terminal ventral bristle. Ventral margin of comb with 76 bristles in addition to 1 proximal bristle with bent tip. Endopod: 1st article with short dorsal alpha-bristle and long terminal spinous betabristle; 2 nd article with long terminal bristle. Note: endopod shown in Figure $29 F$ twisted so that alpha-bristle appears to be on ventral margin and beta-bristle appears to be on dorsal margin (opposite to correct location), and beta-bristle of basis appears to be on dorsal margin of basis instead of on correct ventral location.

Fifth limb: Comb with long spinous epipod bristle; 1 short slender bristle ventral to base of exopod bristle; 3 short bristles close to ventral margin (Figure $30 C$ ). Ventral margin of comb with about 28 bristles.

Sixth limb (Figure 30D): Anterior margin with 2 endite bristles. Ventral margin with 2 spinous anterior bristles separated by space from 10 spinous bristles. Anterior, ventral, and posterior margins and medial surface spinous. Lateral flap spinous but without bristles. Minute medial bristle in anterodorsal corner, if present, obscured.

Seventh limb: With 6 proximal bristles (3 on each side) and 6 terminal bristles (3 on each side); each bristle with 2, 3, or 4 bells. Terminus with opposing combs, each with 5 or 6 opposing spinous combs.

Furca: Missing from врвм-S 14546.

Bellonci Organ (Figure 30E): Elongate with rounded tip.

Eyes (Figure 30E): Lateral eye with black pigment and about 10 ommatidia along outer edge and 4 or more ommatidia hidden by black pigment. Medial eye slightly smaller than lateral eye, with light amber color.

Gills: Posterior ends of gills not reaching past posterior end of body. Each side with 6 or 7 gills, some with nodes along posterior edges.

Genitalia (Figure 30F): Oval with coiled structures on each side of body adjacent to about 3 obscured bristles.

Lips and posterior of body: Fragmented.

REMARKs: The appendages of врвм-S 14546 are described because its carapace differs from that of the holotype from O'ahu in the carapace being oval rather than pearshaped. The appendages of врвм-S 14546 do not differ materially from those of the holotype. The oval shape of the Kaua'i specimen could be caused by distortion. The absence of a furca from the specimen suggests that it may have been stressed.

\section{Parasterope sp.}

material examined: Maui: Sta. H2, Kahului Harbor Pier 2, врвм-S 14548, 1 specimen.

Distribution: Maui (this paper). 

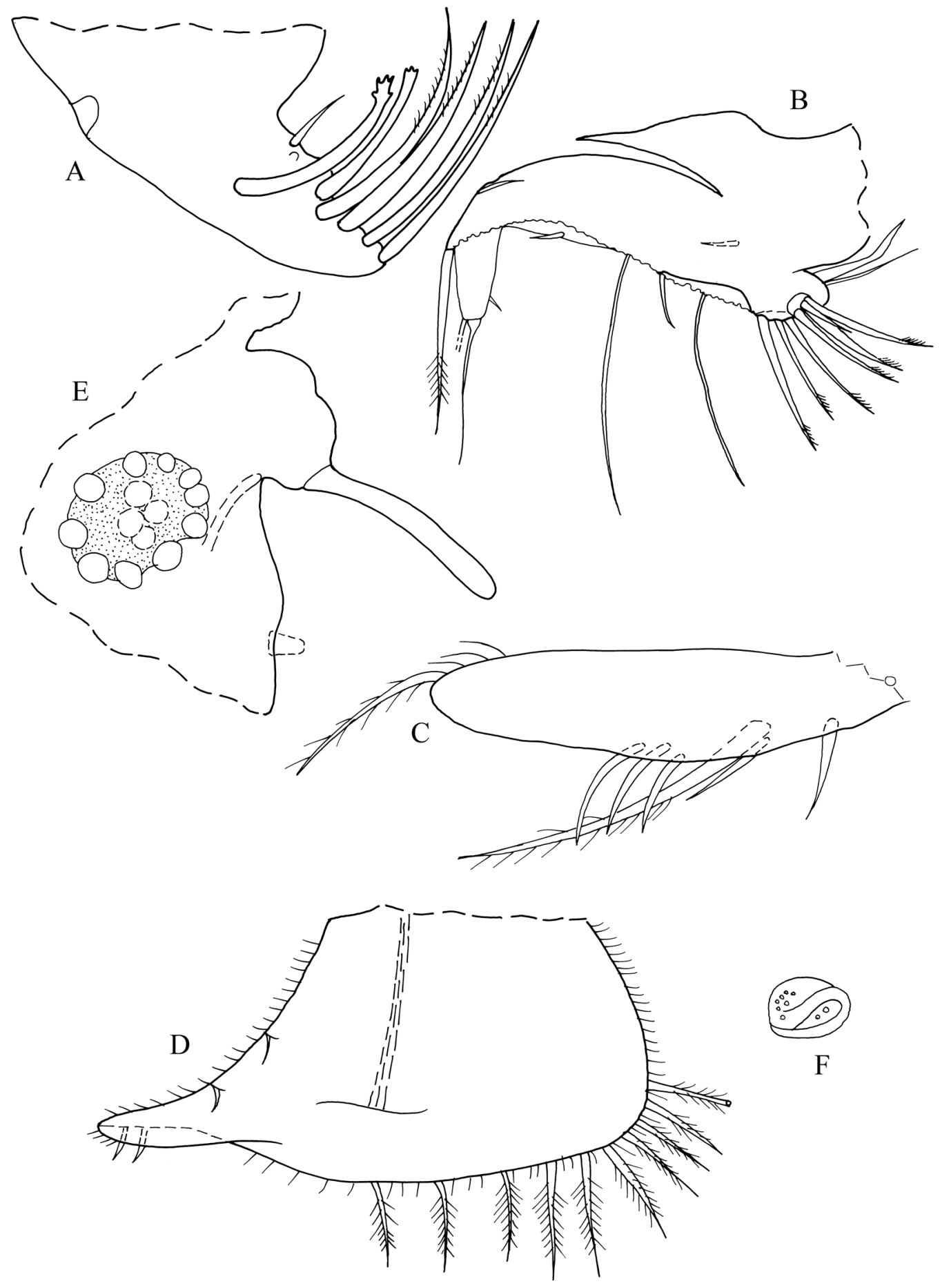

Figure 30. Parasterope gamma, врвм-S 14546, adult female: $A$, basis endite right mandible, medial view; $B$, right maxilla, medial view; $C$, comb right 5 th limb, medial view; $D$, left 6 th limb, lateral view; $E$, anterior of body from right side showing right lateral eye, medial eye, Bellonci Organ, and anterior process; $F$, left genitalia. 


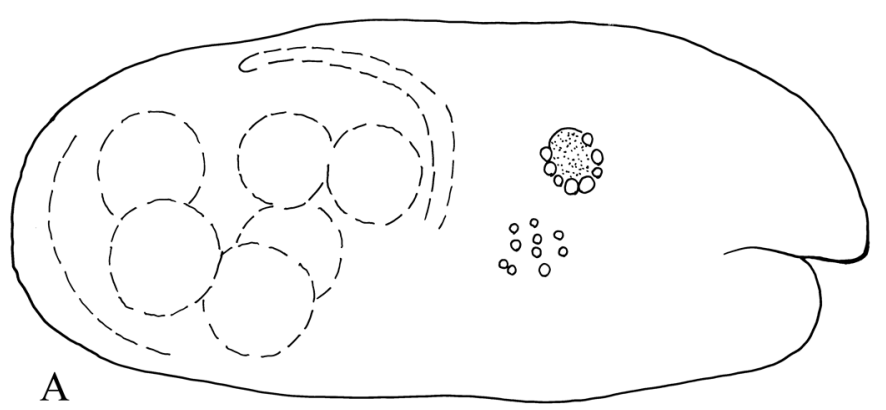

A

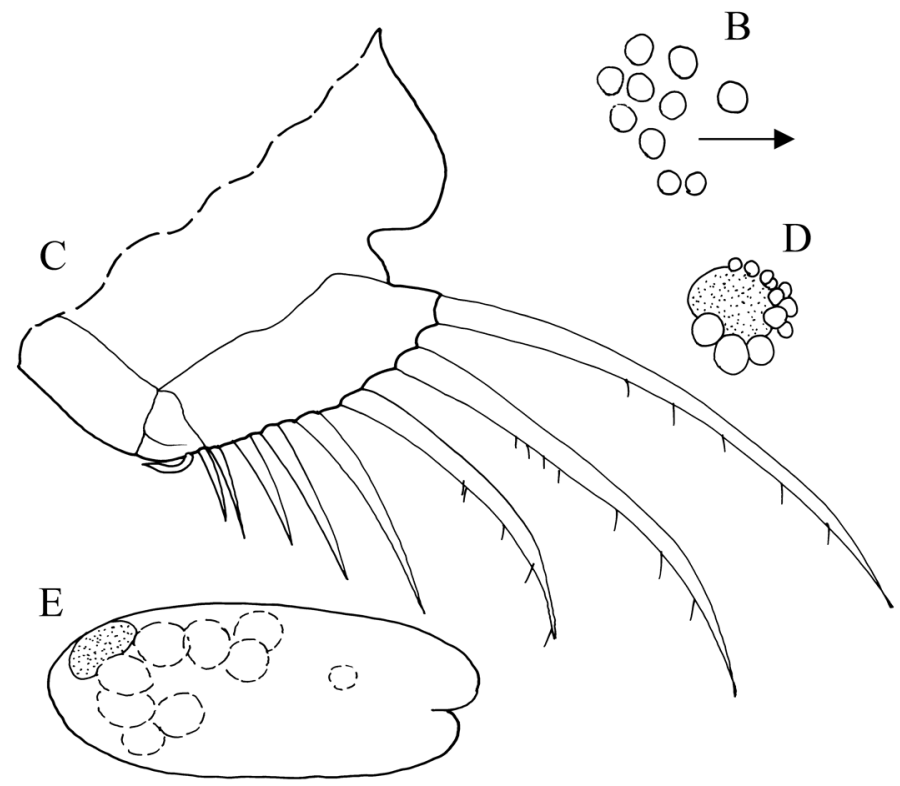

Figure 31. Cylindroleberis kappa, врвм-S 14549, adult female: $A$, complete specimen, length $1.26 \mathrm{~mm}$; $B$, central adductor muscle attachments right valve, outside view; $C$, right lamella of furca, lateral view; $D$, right lateral eye, lateral view. E, Cylindroleberis kappa, врвм-S 14730, adult female, length $1.50 \mathrm{~mm}$.

Parasterope moseri Kornicker, HarrisonNelson \& Coles, n. name

Parasterope zeta Kornicker et al., 2007:75, figs. 40-44.

Not Parasterope zeta Kornicker, 1986:47, figs. 18-20.

material examined: None.

Distribution: French Frigate Shoals, Waikìkī.

Genus Cylindroleberis Brady, 1868

TYPE SPECIEs: Cypridina mariae (Baird, $1850)$.
Distribution: Circumglobal between latitudes of about $58^{\circ} \mathrm{N}$ and $26^{\circ} \mathrm{S}$. Generally part of the benthos in shallow water (Kornicker et al. 2007).

Cylindroleberis kappa Kornicker et al., 2007 Figure 31

Cylindroleberis kappa Kornicker et al., 2007:97, figs. 55-67.

HоLотуре: врвм-S 12836, ovigerous female on 3 slides and in alcohol. 
Type locality: Sta. 11, Kāne'ohe Bay, O'ahu, Hawaiian Islands.

MATERIAL EXAmined: Kaua'i: Sta. Har1, Nāwiliwili Harbor main dock, врвм-S 14730, 1 specimen; Sta. Har3, Port Allen main docks, врвм-S 14549, 1 adult female in alcohol; Sta. K2, Nāwiliwili Small Boat Harbor, врвм-S 14551, 1 ovigerous female. Hawai'i: Sta. H2, Kawaihae Harbor, врвм-S 14550, 2 ovigerous females, USNM 1121720, 1 adult male.

Distribution: Hawaiian Islands: Kaua'i, O'ahu, and Hawai'i (Big Island).

SUPPLEMENTARY DESCRIPTION OF ADULT FEMAle (Figure 31): Carapace elongate with parallel ventral and dorsal margins (Figure $31 A$ ).

Central adductor muscle scars (Figure $31 A, B)$ : With about 10 ovoid attachments.

Carapace size (length, height in $\mathrm{mm}$ ): врвм-S 14549, 1.26, 0.55; врвм-S 14730, $1.50,0.61$.

Lateral eye (Figure 31 $A, D, E$ ): Well developed with many ommatidia and black pigment.

Furca (Figure $31 C$ ): Each lamella with 7 stout claws followed by 2 bristlelike claws (last bristlelike claw pointed backward).

Eggs (Figure 31A,E): врвм-S 14549 with 12 eggs in marsupium and unextruded eggs. в Рвм-S 14730 with 12 eggs in marsupium.

SUPPLEMENTARY DESCRIPTION OF ADUlt male: Carapace size (length, height in $\mathrm{mm}$ ): врвм-S 14551, 2.16, 1.08. Carapace larger than in male described by Kornicker et al. (2007) (length 1.50, height 0.71).

\section{DISCUSSION}

Springer (1982:111) concluded that "Recent Ostracods in the suborder Myodocopina, especially the benthic species, generally tend to have localized distributions, and are generally absent from the Pacific Plate nonmarginally." Our studies indicate that myodocopids are fairly well represented in the vicinity of nonmarginal islands on the Pacific Plate, with 17 species collected in the vicinity of the Hawaiian Islands, and 13 species collected in the vicinity of Enewetak Atoll (Kornicker 1991).
The species present on distant islands do have localized distributions, but many genera are widespread.

\section{ACKNOWLEDGMENTS}

We thank Ralph DeFelice and P. Reath, Bishop Museum, for collecting the specimens upon which this paper is based. All collecting was funded and given logistical support by the U.S. Fish and Wildlife Service. Maps supplied by S.L.C. were modified by Molly Kelly Ryan, Smithsonian Institution. Camera lucida drawings by L.S.K. were inked by Mary Ellen Didion-Carsley of Media Art and Design.

\section{Literature Cited}

Baird, W. 1850. Description of several new species of Entomostraca. Proc. Zool. Soc. Lond. 18:254-257.

Brady, G. S. 1868. A monograph of the Recent British Ostracoda. Trans. Linn. Soc. Lond. 26 (2) [1870]: 353-495.

Brady, G. S., and A. M. Norman. 1896. A monograph of the marine and freshwater Ostracoda of the North Atlantic and of northwestern Europe. Sci. Trans. R. Dublin Soc. (2) 5 (12): 621-784.

Cohen, A. C., and L. S. Kornicker. 1975. Taxonomic indexes to Ostracoda (suborder Myodocopina) in Skogsberg (1920) and Poulsen $(1962,1965)$. Smithson. Contrib. Zool. 204:1-29.

Coles, S. L., P. R. Reathe, P. A. Skelton, V. Bonito, R. C. DeFelice, and L. Basch. 2003. Introduced marine species in Pago Pago Harbor, Fagatele Bay and the National Park Coast, American Samoa. Bishop Mus. Tech. Rep. 26.

Kornicker, L. S. 1967. The myodocopid ostracod familes Philomedidae and Pseudophilomedidae (new family). Proc. U.S. Natl. Mus. 120 (3580): 1-35. 1975. Antarctic Ostracoda (Myodocopina). Vols. 1 and 2. Smithson. Contrib. Zool. 163:1-720.

1976. Benthic marine Cypridinacea from Hawaii (Ostracoda). Smithson. Contrib. Zool. 231:1-24. 
1978. Harbansus, a new genus of marine Ostracoda, and a revision of the Philomedidae (Myodocopina). Smithson. Contrib. Zool. 260:1-75.

. 1983. The ostracode family Cypridinidae and the genus Pterocypridina. Smithson. Contrib. Zool. 379:1-29.

- 1986. Cylindroleberididae of the western North Atlantic and the northern Gulf of Mexico, and zoogeography of the Myodocopina (Ostracoda). Smithson. Contrib. Zool. 425:1-139.

- 1991. Myodocopid Ostracoda of Enewetak and Bikini atolls. Smithson. Contrib. Zool. 505:1-140.

Kornicker, L. S., and F. E. Caraion. 1974. West African myodocopid Ostracoda. Smithson. Contrib. Zool. 179:1-78.

Kornicker, L. S., and E. HarrisonNelson. 2005. Ostracoda from Johnston Atoll, Pacific Ocean, and proposal of a new tribe, Bruuniellini (Myodocopina: Cylindroleberididae). Pac. Sci. 59:323362.

2006. Ostracoda of Tutuila, American Samoa. Pac. Sci. 60:243-259.

Kornicker, L. S., E. Harrison-Nelson, and S. L. Coles. 2007. Ostracoda (Myodocopina) from $\mathrm{O}^{\prime}$ ahu and French Frigate Shoals, Hawaiian Islands. Bishop Mus. Bull. Zool. 8:1-127.

Kornicker, L. S., and G. C. B. Poore. 1996. Ostracoda (Myodocopina) of the SE Australian continental slope. Smithson. Contrib. Zool. 573:1-186.

Kornicker, L. S., and B. A. Thomassin. 1998. Ostracoda (Myodocopina) of the Tuléar Reef Complex, SW Madagascar. Smithson. Contrib. Zool. 595:1-134.

Milne-Edwards, M. 1840. Ordre des Cyproides ou des Ostracodes. Histoire $\mathrm{Na}$ turelle ou des Ostracodes. Histoite Naturelle des Crustaces 3:393-411. Librairie encyclopédique de Roret, Paris.

Müller, G. W. 1906. Ostracoda. In Wissenschaftliche Ergnebnisse der Deutsche Tiefsee-Expedition ... 1898-1899, 8 (2): 1-154 + pls. 1-31. G. Fischer, Jena, Germany.

Poulsen, E. 1962. Ostracoda-Myodocopa, 1:
Cypridiniformes-Cypridinidae. Dana-Rep. Carlsberg Found. 57:1-414.

1965. Ostracoda-Myodocopa, 2: Cypridiniformes-Rutidermatidae, Sarsiellidae and Asteropidae. Dana-Rep. Carlsberg Found. 65:1-485.

Sars, G. O. 1865 [1866]. Oversigt af Norge marine Ostracoder. Forhandlinger I Vidensk, Selskabet I Christiania 8:1-130.

Skogsberg, T. 1920. Studies on marine ostracods. I: Cypridinids, halocyprids, and polycopids. Zool. Bidr. Upps., suppl. 1:1-784.

Springer, V. G. 1982. Pacific Plate biogeography, with special reference to shorefishes. Smithson. Contrib. Zool. 367:1182.

\section{Appendix}

Station Locations and Descriptions and Number of Specimens of Each Species of Myodocopa Collected in the Vicinity of Kaua'i, Moloka'i, Maui, and Hawai'i

Kaua'i

Collected by P. Reath

Station Har1, 11 November 2002, Nāwiliwili Harbor main dock, $21^{\circ} 57^{\prime} 26.1^{\prime \prime} \mathrm{N}, 159^{\circ} 21^{\prime} 39.7^{\prime \prime} \mathrm{W}$, depth $0.3-10 \mathrm{~m}$

Paravargula trifax: 1 specimen Cylindroleberis kappa: 1 specimen

Station Har3, 13 November 2002, Port Allen main docks, $21^{\circ} 54^{\prime} 9.9^{\prime \prime} \mathrm{N}, 159^{\circ} 25^{\prime} 31.3^{\prime \prime} \mathrm{W}$, depth $0.3-10 \mathrm{~m}$

Paravargula trifax: 55 specimens

Pterocypridina colesi: 19 specimens

Cylindroleberis kappa: 1 specimen

Parasterope gamma: 1 specimen

Station Har4, 13 November 2002, Port Allen Harbor entrance, $21^{\circ} 54^{\prime} 3.5^{\prime \prime} \mathrm{N}, 159^{\circ} 35^{\prime} 49.5^{\prime \prime} \mathrm{W}$, depth $7.5-10.5 \mathrm{~m}$

Cypridina alpha: 1 specimen

Harbansus box: 1 specimen

Collected by R. DeFelice

Station K1, 26 October 1996, Nāwiliwili Commercial Boat Harbor, $21^{\circ} 57^{\prime} 14.6^{\prime \prime} \mathrm{N}, 159^{\circ} 21^{\prime} 27.5^{\prime \prime} \mathrm{W}$, depth $0.3-10 \mathrm{~m}$ Paravargula trifax: 1 specimen

Station K2, 26 October 1996, Nāwiliwili Small Boat Harbor, $21^{\circ} 56^{\prime} 59.5^{\prime \prime} \mathrm{N}, 159^{\circ} 21^{\prime} 30.6^{\prime \prime} \mathrm{W}$, depth $0.3-10 \mathrm{~m}$ Cylindroleberis kappa: 1 specimen

Station K3, 26 October 1996, Port Allen, 21 $54^{\prime}$ 6.9" $\mathrm{N}, 159^{\circ} 35^{\prime} 23.8^{\prime \prime} \mathrm{W}$, depth $0.3-10 \mathrm{~m}$ Paravargula trifax: 124 specimens Pterocypridina colesi: 10 specimens Parasterope gamma: 2 specimens 
Moloka'i

Collected by P. Reath

Station H1, 28 January 2003, Hale O Lono within small boat harbor, $21^{\circ} 5^{\prime} 23.7^{\prime \prime} \mathrm{N}, 157^{\circ} 15^{\prime} 04.0^{\prime \prime}$ W, depth 0-5 m Cypridina alpha: 1 specimen

Station H2, 28 January 2003, Hale O Lono reef outside small boat harbor, $21^{\circ} 5^{\prime} 1.4^{\prime \prime} \mathrm{N}, 157^{\circ} 14^{\prime}$ 57.7" W, depth 9-12 m Cypridina alpha: 1 specimen

Station H3, 30 January 2003, Kaunakakai reef, $21^{\circ} 4^{\prime}$ $59.6^{\prime \prime} \mathrm{N}, 157^{\circ} 02^{\prime} 34.9^{\prime \prime} \mathrm{W}$, depth 7-10 m Cypridina alpha: 7 specimens

Station H4, 30 January 2003, Kaunakakai dock, $21^{\circ} 5^{\prime}$ $05.0^{\prime \prime} \mathrm{N}, 157^{\circ} 01^{\prime} 54.0^{\prime \prime} \mathrm{W}$, depth $0-7 \mathrm{~m}$

Cypridina alpha: 68 specimens

Pterocypridina colesi: 10 specimens

Maui

Collected by P. Reath

Station H1, 31 March 2003, Kahului Harbor Pier 1, $20^{\circ} 54^{\prime} 0.5^{\prime \prime} \mathrm{N}, 156^{\circ} 28^{\prime} 9.8^{\prime \prime} \mathrm{W}$, depth $0.2-9 \mathrm{~m}$ Paravargula trifax: 72 specimens Parasterope gamma: 1 specimen

Station H2, 31 March 2003, Kahului Harbor Pier 2, $20^{\circ} 53^{\prime} 53.5^{\prime \prime} \mathrm{N}, 156^{\circ} 28^{\prime} 13.2^{\prime \prime} \mathrm{W}$, depth $0.2-$ $6.5 \mathrm{~m}$

Paravargula trifax: 6 specimens Pterocypridina colesi: 22 specimens Parasterope gamma: 5 specimens Parasterope sp.: 2 specimens

Station H3, 2 April 2003, Mā'alaea reef, 20 47' 31.6"

$\mathrm{N}, 156^{\circ} 30^{\prime} 45.8^{\prime \prime} \mathrm{W}$, depth 5.5-7.5 m

Cypridina alpha: 2 specimens

Paravargula trifax: 16 specimens

Parasterope gamma: 25 specimens
Station H4, 2 April 2003, Mā'alaea Harbor, 20 47' $37.5^{\prime \prime} \mathrm{N}, 156^{\circ} 30^{\prime} 50.9^{\prime \prime} \mathrm{W}$, depth $0.2-4.5 \mathrm{~m}$ Cypridina alpha: 2 specimens Parasterope gamma: 1 specimen

Collected by R. DeFelice

Station M1, 23 November 1996, Mā'alaea outside Cypridina alpha: 8 specimens

Station M2, 23 November 1996, Mā'alaea small boat harbor Paravargula trifax: 4 specimens

Station M3, 24 November 1996, Kahului Harbor Pier 1

Paravargula trifax: 241 specimens

Pterocypridina colesi: 31 specimens

Parasterope gamma: 1 specimen

Hawai'i (Big Island)

Collected by P. Reath

Station H1, 23 June 2003, Kawaihae reef, $20^{\circ} 01^{\prime}$ $55.5^{\prime \prime} \mathrm{N}, 155^{\circ} 50^{\prime} 9.4^{\prime \prime} \mathrm{W}$, depth 4-9 m Cypridina alpha: 14 specimens

Station H2, 23 June 2003, Kawaihae Harbor, 20 02' $25.5^{\prime \prime} \mathrm{N}, 155^{\circ} 49^{\prime} 58.9^{\prime \prime} \mathrm{W}$, depth 0-7.5 m Cypridina alpha: 12 specimens Cylindroleberis kappa: 3 specimens

Station H3, 28 June 2003, Leleiwi Point, 19 44' 14.4" $\mathrm{N}, 155^{\circ} 01^{\prime} 16.5^{\prime \prime} \mathrm{W}$, depth 6-15 m Cypridina alpha: 3 specimens

Station H4, 28 June 2003, Hilo Harbor, 19 $44^{\prime} 05^{\prime \prime}$ $\mathrm{N}, 155^{\circ} 03^{\prime} 25.1^{\prime \prime} \mathrm{W}$, depth 0-9 m Cypridina alpha: 3 specimens Pterocypridina colesi: 2 specimens

Collected by R. DeFelice

Station M1, 9 June 1997, Hilo Harbor Cypridina alpha: 2 specimens Pterocypridina colesi: 4 specimens 
